WYDZIAEY POLITECHNICZNE KRAKÓW BIBLIOTEKA G€ÓWNA

L. inw. 
Biblioteka Politechniki Krakowskiej

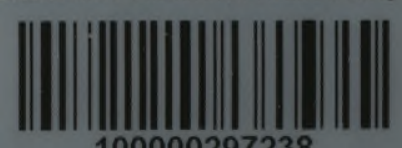
100000297238 




\section{BRITISH CANALS \\ PROBLEMS AND POSSIBILITIES}

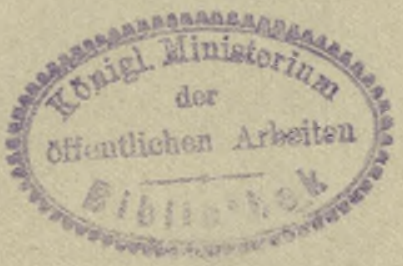





\section{BRITISH CANALS}

\section{PROBLEMS AND POSSIBILITIES}

- BY

J. E. PALMER

FROM 1889 TO 1906 A DIRECTOR OF THE GRAND

CANAL COMPANY (IRELAND)
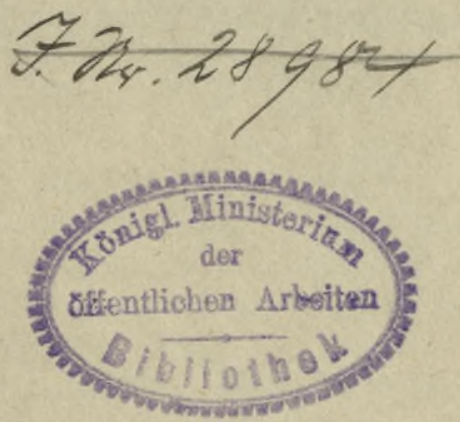

T. F ISHER U N W I N

LONDON : ADELPHI TERRACE

LEIPSIC : INSELSTRASSE 20

1910 


\section{BHBLIOTEKA POLIECHHIQZH KRAKÓW}

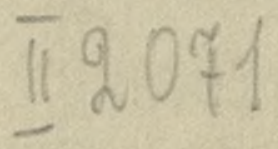

(All rights reserved.)

Akc. Wir. $\quad 843149$ 


\section{PREFACE}

THE purpose of this book is to give the more important features of practical interest in connection with the canal problem as they now present themselves in this country, together with suggestions as to needed reforms and as to the solution of the problem. It is believed that an epitome of the canal question such as this book provides will be acceptable to many who have not time or opportunity to read the rather numerous volumes containing the evidence and report of the Royal Commission.

During the past twenty years the author has given considerable attention to canal matters. He has visited a number of the principal canals and river navigations in the United Kingdom, France, Germany, Belgium, Holland, Norway, Sweden, Austria, Italy, and the United States, and has attended several of the International Canal Congresses, held at various inland waterway centres in Europe.

A literary man, whose opinion is respected, once said that a good way to write a book is to read what is worth reading on the subject you are going to write about, and bear it in mind while writing what you have to say. An endeavour has been 
made in connection with these pages to follow that advice; but note-taking has been necessary in addition to reading.

The author is indebted for information to the following :

Papers by the late Mr. L. F. Vernon-Harcourt, M.Inst.C.E., and by Mr. J. A. Saner, M.Inst.C.E., in the Minutes of Proceedings of the Institute of Civil Engineers, and elsewhere.

Priestley's " Historical Account of the Navigable Rivers, Canals, and Railways of England ";

Messrs. Forbes and Ashford's "British Canals".;

Reports of Parliamentary Committees and Royal Commissions ;

British Consular Reportsr;

Reports of International Canal Congresses;

Reports of Society of Arts Conferences.;

French Government Reports ; and

New York State Board of Public Works Reports.

Memoranda made while reading for personal information, years before writing this book was suggested, have also been made use of $*$; and as the sources of these notes are now unknown, some acknowledgments may be due that cannot be made. A magazine article of the author's is also quoted from, and a memorandum he submitted to the Royal Commission on Canals, a portion of which was printed in the appendix to the Commission's report of evidence. 


\section{CONTENTS}

CHAP.

PREFACE . $\quad$. $\quad$. $\quad 5$

I. INTRODUCTORY

II. THE GENERAL POSITION • + $\quad$ * $\quad$ I7

III. IS CANAL OR RAIL TRANSPORT THE CHEAPEST? - 45

IV. RAILWAYS VERSUS CANALS • • $\quad 65$

v. INLAND WATERWAYS IN OTHER COUNTRIES

(FRANCE, GERMANY, HOLLAND, BELGIUM, THE UNITED STATES, ITALY) . $\quad . \quad$ IO4

VI. WHAT IS NEEDED * . . . 156

VII. STATE CONTROL OR PRIVATE ENTERPRISE - I89

VIII. IRISH INLAND WATERWAYS . . 220

IX. CONCLUSION 



\title{
BRITISH CANALS
}

\author{
C H A P TER I
}

\section{INTRODUCTORY}

A WELL-KNOWN inland waterway engineer said a few years ago, in a paper, or in a discussion that followed, at the Institution of Civil Engineers, that the commercial classes in England needed to be educated in the advantages of canals. This, perhaps, is not astonishing when the course of events with regard to railways and canals during the past couple of generations is borne in mind. Yet it is strange that a great commercial nation should have long neglected so economical a mode of transport. Apart from those having connection with canals, comparatively little sometimes seems to be known of their advantages, and business men do not always know their practical value. Yet from time immemorial water transport has been one of the most important means of conveyance.

There is good reason for thinking that most of the chief cities of the world have become prosperous, important, wealthy, and great, at one time or another, largely owing to the advantages they. 
possess in having natural navigable waterways at their doors. Most of such cities are alongside salt water: some are upon large rivers. Although in many cases the greatness of these cities may not have been generally attributed to the advantages resulting from the use of natural waterways, the benefits would be so great, and would give seaports so much advantage over inland towns, that there can be no doubt as to natural waterways having played an important, even if unrecognised, part in bringing prosperity to cities and towns located on their shores. There are, of course, exceptions. Rome, Moscow, and Paris, for instance, became great from other causes; but that does not detract from the general truth of the hypothesis. Venice, Genoa, Hamburg, Antwerp, Rotterdam, London, Liverpool, Glasgow, Cardiff, New York, Boston, and Philadelphia are all places that owe much of their greatness to the economic advantages of water conveyance. Many towns on navigable rivers similarly owe their prosperity very largely to the facility and cheapness of water transport. The value of water transport is well shown by the gradual conversion of the Clyde, which was originally a fordable stream below Glasgow, into what is virtually a large ship canal. The Tyne, the Tees, and other rivers are also instances of navigable waterways rendering great services to industry.

Although the chief causes of commercial predominance in past times cannot now always be easily determined, there is no doubt as to the commercial advantages resulting from location in a position that will diminish the cost of carriage. The lower the freight the larger the trade is fre- 
quently the rule. It is well known that various business firms and companies have removed their. establishments from inland localities to coast towns, and that others have built new premises at seaports in order to save the cost of inland carriage. This helps to show, to those who did not know it already, the importance of the freight question in a commercial country.

Having regard to the experience that England had of canals before the railway era, it is somewhat astonishing that so great a trading nation should have virtually left inland waterways outside the sphere of its activities for many years. Yet that is what has been done.

The principal parties concerned with this question are the commercial community-the freightpayers - on the one hand, and the different branches of the carrying trade on the other. The subject is distinctly a business one. Although it is known as the "canal question," rivers that are naturally navigable, and those that have been artificially. canalised, come within its scope, as well as canals. Taking a broad view of the whole problem, it is not necessarily altogether a canal question, but rather a question of what is the cheapest mode of inland transport available at the present time; for cheap freights, or as cheap freights as are practicable, are virtually a necessity in the commercial world in these days of keen competition.

The trading public naturally desire to have their merchandise carried as cheaply as possible. Freight-payers point to low freights in other countries, and ask for somewhat similar rates in the British Isles. The carrying trade reply that freights have from time to time been lowered, 
and lowered very appreciably, and that owing to higher expenses and different conditions in this country they are unable to make rates that appear as low as the cheaper foreign freights, and there is not really the difference that is often supposed, because British freight rates in most cases include collection and delivery at each end of the journey, while continental rates generally do not. The carrying companies point out their small profits, which show a considerably smaller percentage on capital than is generally made in other kinds of business.

The importance of cheap freights needs little explanation. The cost of transport affects people of all classes, because some of the things they buy have borne the cost of carriage ; but it is of course only traders who pay an appreciable amount of freight that are much interested in the question. The success of various branches of industry depends to some extent on the cost of carriage. In many cases it is the cost of freight, or carriage, that determines whether sales can be made at a fair profit, or whether they can be made at all. This is so especially with commodities whose prices are much affected by the cost of transport. Most of the goods carried in large quantities to and from inland places are of sufficiently low values for the freight, when added, to form an appreciable part of the price. Coal, iron, and building materials, for instance, many raw materials, and agricultural and other products of every-day use are low enough in cost to be appreciably affected in price when freight is added. It is obviously of importance to business people that carrying trade arrangements should be as efficient as possible. 
Generally speaking, canals are not now as important as railways. They cannot be as universally useful. They no longer carry passengers, and their use is restricted to suitable parts of the country. The coasting trade between seaports, while it competes with some inland routes, leaves considerable areas almost unaffected; but even where there is competition by sea with inland routes it is, at least for some trades, rather ineffective owing to irregularity caused by the weather. The chief use of road motors seems likely to be in acting as feeders for railways and canals, and carrying traffic for short distances, thus superseding horse-hauled traffic.

Each mode of transport has advantages of its own which others have not; and each is consequently best suited for a somewhat different purpose, just as racehorses and draught horses, racing yachts, and cargo steamers can each accomplish something that the other cannot do to advantage.

Although canals are of less importance in some respects than in the days when they had virtually a monopoly of inland goods traffic, they have one great advantage over railways, that of cheapness, where the conditions are suitable; for the cost of transport is less on efficient waterways than on railways: and as the money test is the allimportant one in commerce the economy of waterway conveyance, compared with railway conveyance, makes inland waterways important, where there is enough traffic for them.

It seems rather an anomaly in these days of great competition, when ideas and possibilities are quickly utilised and turned to account, that 
there should remain obvious practical possibilities unavailed of. Material progress, however, is irregular and unequal; and while immense development has taken place in some directions, such as weaving machinery, printing machinery, bicycles, and many other things, there are others that remain in the same stages of development as generations ago. The potter's wheel, by means of which round earthenware vessels are made, is the same as the potter's wheel of two thousand years ago. Is it because no appreciable improvement in form, structure, or otherwise is possible that canal boats and barges have remained very. much as they were a hundred years ago, while during the same period other kinds of craft, such as racing yachts and ocean liners, have gradually reached a high state of development? Possibly some branches of commercial activity that have lagged behind might, by a comprehensive and logical survey of this wide field of human knowledge, be brought up to a level more nearly corresponding with progress made in other directions. By applying in suitably modified or developed forms, to meet the purposes in view, methods, principles, or mechanisms used in connection with other things, it is at least possible that improvements might be made in some directions. Notwithstanding the keen competition of the times, there are probably numbers of things that could be improved with profit to whoever sees how advantageous improvements may be made. The production of five-masted schooners by American shipbuilders, with more numerous sails of small size than had old schooners of corresponding sizes, so handled as to economise in the number of the 
crew, was a development that would have been of great value had it come before steamers had largely superseded sailing vessels for commercial purposes. It is an instance of an essential improvement made in a design that many competent persons interested in that particular trade believed could not be improved upon. This suggests the possibility of further improvements being made in connection with canals and canal barges, if more attention were paid to them.

A generation or more ago other countries as well as Great Britain had antiquated canal systems. But now in the chief commercial countries of Europe that are suitable for canals the waterway systems have been for the most part modernised, with great advantage to trade.

The greater interest shown in inland waterways in recent years is to be attributed partly to the knowledge gradually spreading that during the past thirty or forty years large amounts of money have been spent on improving and constructing canals, and on canalising rivers, on the Continent ; and that there are low freights on these new and improved waterways. This knowledge has done much to alter English opinion on the subject. For the past quarter of a century there appears to have been a slow and steady growth of opinion that if the canals were put into a position to do as well for freight-payers as waterways are capable of doing, a saving of freight could be effected with benefit to many industries. This growth of opinion is largely owing to the work of various associations, both mercantile and technical. The Associated Chambers of Commerce, the International Congress on Inland Navigation, the 
Society of Arts, the Institution of Civil Engineers, and the Mansion House Association of Railway. and Canal Traders (London) have all taken part in promoting revival of interest in the subject.

Traders sometimes seem to expect great results from a resuscitation of canals-greater results, perhaps, than may be practicable. It seems necessary to remember that nowadays numbers of things cost more in the British Isles than in some other countries, owing to the higher cost of labour, the higher value of property, and other causes.

The appointment by Government of the Royal Commission on Canals, in January, 1906, to reinvestigate the position and possibilities of inland waterways in the United Kingdom, was a recognition of the increasing importance with which the subject is now regarded. The technical and financial parts of the problem do not present insuperable difficulties. Somewhat similar problems have been solved with general satisfaction in several other countries : and the various interests involved, although it is not to be expected that they can be brought into entire concurrence, can, it is to be hoped, be so fairly dealt with as to cause general acceptance of a wise and much needed project of canal improvement. 


\section{CHAPTER II}

\section{THE GENERAL POSITION}

THE general position of canals and the canal carrying trade in England is unsatisfactory to the majority of those concerned. Traders are dissatisfied because freights are thought to be higher than those paid by their competitors in Germany, Belgium, and elsewhere ; and because the canals, although they might perhaps do a little better, cannot do very much better than they are doing in their present physical condition, and in the circumstances in which they find themselves with regard to the railways. To shareholders the state of things cannot be very pleasing, for while a few inland waterway companies pay moderate dividends, many of them make a very small return, or none at all. And Parliament can hardly congratulate itself on the fact that legislation resulting from the labours of various Royal Commissions and Parliamentary Committees has not yet placed matters on a satisfactory basis, although this has been done in several European countries.

A brief outline of the course of events leading up to the present time will perhaps best explain the position of things. It will show how the present situation has come about. During the 
fifty or sixty years that preceded the introduction of railways canals had been found to be of immense service in developing and increasing the trade of the country. Goods were carried on them much more cheaply than by road. The impetus given to industry was so great that the influence of transport upon the development of trade, where little or none previously existed, was possibly over-estimated, for some lines of canal were made for which eventually there was not sufficient traffic. Canals had enabled traders to send goods to more distant places than hitherto ; and larger quantities of merchandise were carried by canal at far less cost per ton than had been possible previously by means of carts and pack-horses.

Although a few canals had been made in earlier times, such as the Fossdyke Canal, in Lincolnshire, the short Exeter Ship Canal, and some of the canals in the fen districts, the general making of canals in England commenced with the Duke of Bridgewater's famous canal, begun in 1759, between the Mersey and Manchester. It was constructed to carry coal from the Duke's mines to that town and to Liverpool. The cost of carriage, we are told by Messrs. Forbes and Ashford in their "British Canals," from Liverpool to Manchester was lowered from forty shillings per ton to twenty pence per ton by this enterprise. It was as notable a work in its day as the Manchester Ship Canal is in ours. It led to many other canals being planned and constructed.

In most countries where canals have been made to a considerable extent, their history, as an important element in commerce, has been somewhat similar. Inland traffic in England at the time of the 
canal-making era was of course far more local in character than it is now. The earlier canals made were consequently more or less local in extent : so at least it seems now, in relation to the requirements of the present day. Under the circumstances it is not surprising that the waterways and locks were of various sizes. Fortunately the desirability of connecting many canals was early realised; but such canals were frequently of different dimensions. Before canal-making was discontinued owing to the introduction of railways, many of the chief manufacturing and producing districts of that time, and the important towns, had navigable waterway communications. The principal watersheds of the country had canals and river navigations, and some of these were connected with each other by means of canals constructed over altitudes of several hundred feet above sea-level. Some places at considerable elevations were supplied with canals, as they had large traffics, Birmingham, about four hundred feet over sea level, being perhaps the most important. The routes of the existing canals are well chosen from an engineering point of view.

Canals in England appear to have reached their greatest success about 1838 . Railway competition about that time began to injure them; and some of the canal companies are said to have injured themselves, and helped their rivals, by refusing to lower their rates; for they wished to maintain their good dividends. The railways then got traffic from the canals by accepting lower rates. Some canal companies, when threatened by railway competition, proposed to make railways along their lines of canal themselves; and in this way 
they brought railway promoters to terms for the purchase of canals. Other canal companies did construct railways. For a few years canal tonnage was somewhat increased, partly owing to the carriage of railway construction materials; but owing to rates being reduced by growing railway competition, the canal receipts fell, and a little later the falling off was greater. The depreciation in the value of canal shares became very considerable, and many canals were bought by railway companies at low prices. Probably lack of organisation on the part of the canals helped to give the railways an easy victory. Mr. G. C. Thomas, the engineer of the Grand Junction Canal, stated to the Royal Commission on Canals that a strong amalgamation of canals would have taken place in 1846 or ' 47 , if the Birmingham Canal had not been under railway control. In .I 845 , I 846 , and 1847,948 miles of canal came under railway control. After this, further amalgamations and improvements on the part of independent canals were of little use, for the railways had obtained canals that were in the position of connecting links, as well as other important lengths of canal.

A large number of British canals are in much the same condition as sixty or seventy years ago. With the exception of two which have been enlarged and improved, and three or four others which have been improved in lesser degrees, hardly. any are efficient for the needs of the present time, for they were constructed when trade requirements and engineering knowledge were more limited than at the present time. The Aire and Calder Navigation, in Yorkshire, and the River 
Weaver Navigation, in Cheshire, are the notable exceptions. Both have long had very considerable traffics; one in coal from south Yorkshire coalfields to sea-going vessels in the Humber, and the other in salt from Cheshire salt-mines to the Mersey. On the Aire and Calder Navigation $2,810,988$ tons were carried in 1905, and on the Weaver $1,076,572$ tons in the same year. Both have considerable railway competition, but being well equipped, both from engineering and commercial points of view, they do not suffer from it like most of the other canals. The traffics on these two waterways made it practicable from a financial standpoint to enlarge locks and waterways from time to time, so as to lessen the cost of freight; and the reduced rates of freight were the cause of increased traffic, which ultimately led to further enlargements. On the Weaver Navigation the last enlargement was undertaken in 1872 , when locks were provided 220 feet long, 42 feet wide, with I 5 feet of water over the sills. The locks of minimum size are 220 feet by 25 feet by 15 feet. The present enlarged state of this waterway is primarily due to $\operatorname{Sir}$ E. Leader Williams. It is navigable for steam barges of 450 tons, and the locks can accommodate at one locking four barges each having a capacity of 250 tons. The Aire and Calder waterway, which is made up partly of canals and partly of canalised rivers, has also been enlarged more than once in order that its traffic might be carried more economically. Its main locks are 215 feet long, 22 feet wide, with a water depth of 9 feet over the sills; but still larger locks, 460 feet long, are in course of construction, together with a 
waterway having a surface width of 90 feet and a sectional area of 600 square feet. These two waterways compare very well with modern canals abroad as regards efficient dimensions and modern equipment. The tonnages carried annually upon them would never have become so large as they have done had it not been for the low freights brought about by the enlargements. Cause and effect have acted and re-acted on each other. Although there are few canals in Scotland, the usefulness of increased depth of water was recognised there. The Forth and Clyde Canal was first authorised to be 7 feet deep, then was increased to 8 feet deep, and now has a depth of 9 feet 6 inches. The Monkland Canal also was given an increased depth after its original construction.

Most of the English canals are of too small a gauge for their traffic to be carried as cheaply as would be practicable if the locks and waterways were larger. The lack of uniformity of gauge is a hindrance to through traffic : it prevents as large boats being used as would generally be economical; and the continuity necessary for through traffic between important places is interrupted by the railways having in their early days acquired intermediate canals, which are often managed in such a way as to help to divert traffic on to the railways. From the Derbyshire coalfields to London by canal there are four different gauges. Between Liverpool and London there are also that number; and part of the route has narrow locks which only admit boats seven feet wide, carrying thirty tons, which makes through traffic unprofitable. In some circumstances the narrow canals (those with locks only about seven 
feet wide) cannot compete successfully with railways. In some places, however, circumstances are in their favour. These are instances of the condition of things. Lack of co-ordination and of able uniform management has also contributed towards less successful results on the canals as a whole than would otherwise have been the case.

When railways began to extend over the country, the public apparently jumped to the conclusion, and the idea seems to have quickly spread, that canals could not compete successfully with them. It was believed that railways would take most of the canal traffic, just as the canals a number of years before had taken much traffic from the highroads. The superiority of railways in some respects, and for some purposes, is so obvious that it is, perhaps, not astonishing if more varied capacities than they actually possessed were attributed to them. It was overlooked that speed is of less importance than cost of carriage for many kinds of commodities, and it was not generally known that goods can be carried at less cost on water than on rails, provided the best engineering knowledge and methods are availed of in one case as well as the other. As it was generally thought that canals would be superseded, canal companies at the time, perhaps, saw little or no objection to letting railways acquire many large links in the chain of canal communication. The outlook for canals being discouraging, many of the waterways were not well maintained; and, apart from the Aire and Calder and the Weaver Navigations, exceedingly few have been at all enlarged; and these have not been improved on a sufficient scale to make them capable of providing much cheaper 
freights. Consequently, canals became in most cases less and less able, compared with railways, to work effectively. Had they received the benefit of new ideas, improvements, and inventions continuously during the past seventy years, like the railways, they would now have been capable of carrying goods more economically.

If in the early days of railways any competent impartial person had thoroughly investigated the relative merits of canal and rail transport, or had introduced suitably designed steamers on canals, it might have led to effective competition between the two systems ; with the result that canals probably would have been supported and well maintained, and improved from time to time to meet increasing requirements. The mistaken view that canals could not compete successfully with railways, which prevailed for so long after the introduction of the iron road, and which seems to have been carefully fostered by railway men, has, no doubt, been partly responsible for preventing the improvement of canals. One competent witness stated in evidence to the Select Committee on Canals, I883, that new capital was not put into canals because of railway influence, which would take steps to make capital outlay on canals unprofitable. Those interested in keeping canals dormant were watchful, the same witness said, and those who might re-invigorate canals had little interest in doing so.

Exactly how or when the revival of interest in canals began it would be difficult to say. During the period that followed the fall of canals and the rise of railways it must have been known to engineers, but perhaps not to many, that water 
transport was more economical than land transport. It was doubtless also known to some of those connected with the few successful independent canals. Leading public men, perhaps too busy with other things to know much of a matter of this kind, apparently joined with or followed public opinion, instead of rightly guiding it.

From the first coming of the iron road, railway men with little exception seem to have taken an attitude that practically amounted to aggressive competition towards canals. Their policy appears to have been to lessen canal competition as much as possible by any means, legally allowable, that seemed expedient. The policy of discouragement and disparagement of the rival mode of transport, once begun, seems to have been adhered to ever since, with, apparently, little thought of reconsidering the position. The railways have acted in much the same way as many other business organisations and traders have done under somewhat similar circumstances. They have left no stone unturned to get all the business they can for themselves. They are sometimes much blamed for this ; but it ought perhaps to be remembered that in many trades when great exertions are made to obtain business it usually means taking it from rivals in the same trade. Where there is active competition there seems little room sometimes for the principle of "live and let live" to be acted upon. It seems likely that the railways have probably erred less than many other traders, for owing to the strong light of public opinion that is focussed on their work there is likely to be less to complain of than in the case of industries on which no such strong light is thrown. 
It is natural that such a large and important industry as the railway carrying trade should have become a powerful one. What is known as "the railway interest" (a somewhat intangible expression, but one that is well understood and recognised) has long been in existence, and no doubt exercises considerable influence. It is widespread, for officials and shareholders and those who supply railways with materials for construction, maintenance, and working are necessarily a large body. And in many Parliaments up to 1906 the railway interest has been influential, having had considerable numerical strength. Canals and the canal carrying trade suffer because there is hardly any, if any, appreciable canal interest corresponding with the railway interest.

Although public opinion at the time of the advent of railways was generally almost hopeless as to the future of canals, it is evident that there were railway men who knew the value of water transport ; for there would have been little need to acquire canals if they were as unsuited for satisfying trade requirements as railway men sometimes allege. Had not the capabilities of canals as competitors been realised, it would have answered the purposes of the railways to let the canals die a natural death. But instead of adopting that course the controllers of the newer mode of transport acquired various canals which formed parts of main routes between important centres of trade. The chief step taken in this direction was in 1846 , when six important canals were acquired by railway companies. The main object in view can hardly have been anything else than to lessen competition, and the possibility of 
it, and to divert traffic on to the railways. Railway representatives, chief officials, who know the facts, admitted to the Royal Commission on Canals that reduction of rates by railways, in order to secure canal traffic, had been, in their opinion, the principal cause of the decline of canals.

The experience of the Grand Junction Canal Company, who have the chief independent canal route between London and Birmingham, is perhaps more or less typical of the experience of various English canals. A considerable part of the canal is roughly paralleled by the London and NorthWestern Railway. Mr. G. C. Thomas, the engineer of the canal, gave the Royal Commission the following particulars :

Their through traffic in 1838 , when the railways commenced carrying, was 202,134 tons, producing revenue of $£ 93,697$; and in the next seven years, during which there was fair competition with railways, their through traffic rose to 294,257 tons, but the revenue fell to $£ 48,695$, owing to the competition. Then in 1846 , the year that railway companies got either possession or control of the Cromford Canal, the Nottingham Canal, the Birmingham Canals, the Ashby-de-la-Zouch Canal, the Trent and Mersey Canal, and the Stratfordon-Avon Canal, all of which were then of importance in connection with the trade between the Midlands and London, the Grand Junction Canal traffic dropped to 229,000 tons and $£_{3} 6,000$ revenue. In defence of their own interests the Canal Company then became carriers themselves, which led to some increase in the traffic; but it also caused the railways to compete more severely, with the result that the canal traffic steadily de- 
clined until I 870 , since which time it has been stationary until lately. Apparently the railways got all, or nearly all, the through traffic except such as could not be alienated from the canal owing to proximity, saving of cartage, or some other reason of the kind. But, on the other hand, fortunately for the Canal Company, the local traffic (that which begins and ends on the canal) has steadily increased, owing to the natural development of the country, from 746,000 tons in 1838 to $1,646,474$ tons in 1905 .

That is a somewhat typical piece of history; but some canals, especially smaller ones, have fared worse. Dilapidations and silting up, causing reduced sectional area, of the railway-owned Cromford and Ashby-de-la-Zouch Canals have made it impracticable to obtain access by canal to the collieries and factories which would otherwise give traffic to the Grand Junction Canal. The statutory powers obliging railway companies to maintain their canals properly are not enforced, $\mathrm{Mr}$. Thomas alleged, because legal action for this purpose is costly, and the result uncertain.

Railway policy, however, with regard to canals varies according to circumstances. Two of the large railway companies that adopt in some districts what is popularly considered the usual policy as to canals in other localities make use of waterways where it is to their advantage to do so, in one instance owing to the canals being useful feeders to the railway lines, and in another apparently to get traffic that would otherwise go to a competing railway company. The Birmingham Canal Navigations are so largely used by the London and North-Western, the Great Western, 
and the Midland Railway Companies that Mr. Saner, M.Inst.C.E., has described that waterway. as virtually a railway dock. Out of the eight million tons carried annually upon it seven millions are transhipped to or from railways. It is controlled by the London and North-Western Railway. Company. The Trent and Mersey Canal, belonging to the North Staffordshire Railway and Canal Company, a small company, is worked on its merits like an independent canal, but the canal is an important part of the Company's system.

Railways have developed so enormously in this country, while canals, with a few exceptions, have practically stood still, that the condition of things is not at all what it would have been if the two kinds of transport had kept pace with each other. Obviously the railways, for many reasons, but largely because they almost monopolise the traffic in many districts, have a great advantage over the waterways. Mr. S. Fay, the general manager of the Great Central Railway, stated in his evidence to the Royal Commission on Canals that "the competition between canals and railways now is not a very serious matter for the railway companies." Under the circumstances it is sometimes thought astonishing that the canals as a whole have done as well as they have. But the large tonnage carried by some of those in competition with railways shows that the advantages of canals are appreciated by many traders.

Traffic in large quantities in England, as in France, Germany, Belgium, and elsewhere, is to a large extent confined to particular districts-coal and iron districts, for instance, and certain busy manufacturing localities and districts connected 
with big seaports which have a large trade. The bulk of the traffic is in South Lancashire and the watershed of the Mersey, South and West Yorkshire, the Birmingham, Staffordshire, and Midland district, and, in a lesser degree, the London district, and part of the Severn Valley. Where there is an efficient waterway, like the Weaver, or the Aire and Calder Navigation, it gets a great part of the general merchandise traffic such as goes by railway in many districts, as well as the heavy, bulky, and fragile traffic for which waterways are especially suitable. On the Aire and Calder Navigation, the Leeds and Liverpool Canal, the Birmingham Canal, and, to a smaller extent, on the Trent Navigation, tonnage and receipts showed increases during the recent period of good trade, although the situation of these waterways places them in competition with railways.

The figures given in the recently-issued official canal returns for 1905 , compiled by the Royal Commission, show particulars of 3,822 miles of inland navigable waterways in Great Britain, 2, 556 miles owned by independent companies, and 1,266 owned or controlled by railway companies. On the independent canals in Great Britain 28, 168,8 I 3 tons were carried in 1905 , producing a revenue of $£_{1,502,959}$; and on the railway owned and controlled canals 14,191,073 tons were carried, producing a revenue of $£_{546,287}$. It must be pointed out that the actual tonnage is not as large as that here quoted from the Royal Commission statistics, for the total number of tons which has passed over each separate company's waterway is put down, and included in the total; so that traffic which has in one journey passed over two different water- 
ways is included twice, and traffic which has passed over three different companies' waterways is included three times. Owing to this method of compiling the returns the actual tonnage cannot be given. The method adopted in other countries of compiling the number of tons shipped, or consigned, at each place of origin, irrespective of how many separate waterways may be travelled over, enables the actual tonnage to be known. For the reason just given accurate comparisons between the work of the independent canals and that of the railway-controlled canals cannot be made. The figures give no correct idea as to the usual amount of traffic on railway owned and controlled canals. The railway canal tonnage of 14,191,073 tons gives an impression of larger traffic than exists, generally speaking, on railway. canals. Of this amount $8,382,435$ tons are on the Birmingham Canal, leaving only between five and six million tons for all the other railway canals, many of which have so little traffic they. are carried on at a loss, owing to the railway. policy of discouraging canal traffic.

Considering what advantages the railways have over independent canals, their ability to spend capital if they wish, and their ability to influence traffic in the direction they desire, the conclusion to be drawn from the figures can only be that, taken altogether, they have not wished for traffic on their canals, preferring to divert it on to the rails.

The carrying trade on the canals is sometimes undertaken by the canal companies themselves with their own fleets of barges, but to a large extent also by carriers and traders who own boats or 
barges and pay tolls to the canal companies for using the waterways. Manufacturers and merchants have barges and boats solely for their own traffic. The railway companies owning canals do not conduct a carrying trade upon their canals themselves, except in the case of the Shropshire Union Canals, owned or controlled by the London and North-Western Railway, where the traffic does not compete, I believe, to any great extent with the owning Company's railway, and where much of the traffic taken on the canal would otherwise go to different railways. This case is exceptional for that reason : generally speaking, it does not suit the railway policy to carry goods by canal, for it would encourage traffic by a method which the railways evidently think it to their interest to discourage. Mr. Saner states that among the railwaycontrolled canals no improvements have been made, except on the Trent and Mersey Canal, and nothing has been spent on maintenance.

A number of independent canal companies are themselves carriers because a sufficiently large carrying trade cannot be had on their canals unless it is done by a responsible company capable of handling all kinds of traffic, and of providing sufficient boats and facilities such as the railway companies provide-facilities like through rates, warehouses, offices, cranes, and a proper amount of business organisation. Many small carriers own only a few boats, sometimes only one or two, and sometimes confine themselves to certain descriptions of traffic, which is frequently not conducive to an increasing trade, or to a trade of the best kind. This is a condition of things unable to cope with extra traffic sometimes available.; and the small 
carriers are frequently. not as business-like as larger concerns. Some consignors of goods will not employ them, as they are not generally as responsible as large firms or companies, in the event of loss or damage to cargo. It is largely, because the independent carrying canal companies carry goods, and provide facilities, which canals as well as railways must have, if they want to have much traffic, that the independent canals have a larger revenue per mile of canal than the railwaycontrolled canals. But it must be remembered that the revenues from tolls is smaller than the revenues from freights for the same tonnage, for the toll is only a part of the entire cost of carriage. The revenue from tolls being small, the tonnage should be considered in order to appreciate the importance of any traffic. The toll traffic is largely on raw: materials and commodities of low value. The canals owned by companies that are not carriers but only toll receivers (both those that are independent and those that are railway-controlled) are not as well provided with facilities for traffic as the independent carrying canals. If more facilities had been provided, more traffic would have been attracted. The fact of railway companies not generally providing on their canals storage accommodation, and facilities which they know to be essential on their railways, is another item of evidence in support of the opinion that traffic is discouraged on railway-controlled canals. Facilities are provided in some instances, but not generally, as on railways or independent carrying canals. A number of the independent canals that are not carriers, but only toll-receivers, are little or no better provided with facilities for dealing with 
traffic than the railway-owned canals. The railways carry an appreciable amount of traffic that would go by canal if the canals had proper. facilities.

In the very early days of railways, and on many canals at the same period, it was considered that the legitimate business of both was to provide lines, or routes, for those who wished to send vehicles or vessels on them;; it was not thought necessary, that canal companies and railway companies should themselves carry goods. That view seems to have come to the newer modes of transport along with the traffic from the high-roads, on which the road-owner and vehicle-owner are of course distinct. Although the impracticability, of accommodating more than a limited number of trains on the same line of rails at the same time soon made it necessary to change this idea on railways, the non-carrying independent canals have continued the same system, although some of them might have done better for themselves and for traders if they had become carriers and otherwise developed their properties. But, on the other hand, the Grand Junction Canal Company, for instance, have been carriers, and felt obliged to relinquish that branch of their business as unprofitable, owing to severe railway competition, which accomplished its purpose. It is true, some of the non-carrying independent canals have earned small dividendsi; and as the railways were allowed by Parliament a position which enabled them to get the lion's share of the traffic, there was little or no inducement on the part of the canals to incur further capital expenditure, even if capital for fleets of barges, \&c., could have been procured, which would have been 
difficult or impracticable in some instances. In the case of some of the independent non-carrying canals which are of short length, it would not be worth while for them to become carriers. They ought long ago to have been amalgamated with neighbouring canals.

When the Manchester Ship Canal was being constructed, it was thought by some that after its completion a canal revival would come about as a result. No doubt it was thought that the demonstrated success of water carriage on a large scale would benefit inland waterways generally'; but ship canals and barge canals are not quite analogous. Financial considerations in relation to one would not always be a good guide for the other. Ship canals are used either to shorten routes for ocean vessels, or to bring vessels as far inland as is practicable, so as to save the cost of transhipping and of inland freights, which are necessarily higher than freights by sea-going vessels. It appears to have been with the object of lessening the likelihood of the ship canal encouraging fresh canal enterprise that the railways, previous to its opening, took steps to make it unprofitable to its shareholders. They did this by lowering freight rates between Liverpool and Manchester to such an extent that the ship canal could not have any, profit at corresponding rates. The canal had to charge equivalent rates, or it would not get traffic; and it was better that the canal should work at low rates than not at all. Taking a broad view of the interests of Manchester and the surrounding districts, more has been gained than lost by the construction of the ship. canal. The Ship Canal Company, owing to 
increased traffic, have recently been able for the first time to pay the full amount of interest due to Manchester Corporation on debenture loans, which amount to about one-third of the capital outlay. The share capital, about $£_{10,000,000 \text {, }}$ gets no dividends, but it is mostly held by local business people who gain more by their savings on freights than they lose by non-payment of dividends on their canal shares. The general result is therefore locally regarded as satisfactory. Sir Bosdin Leech estimates that the annual saving to Lancashire trade is a million pounds. As a dividend of 5 per cent. on the $£_{10,000,000}$ share capital would be half a million pounds, Manchester and district as a whole consequently gain about half a million annually by the ship canal. Sir Alfred Hickman stated some years ago, when on a deputation to the Board of Trade, that, taking into account the reduction in goods rates, the ship canal was paying: Manchester I7 per cent. It is stated that the average freight charges for imported goods to Manchester are now about onethird of the amount they were when the movement in favour of the ship canal began.

The chairman of the Manchester Ship Canal Company stated to the Royal Commission that although the railways strenuously opposed the canal scheme, yet in the past twelve years railway traffic between Liverpool and Manchester had almost doubled. And Mr. Fay of the Great Central Railway admitted to the Commission that the railways had benefited greatly from the growth of Manchester since the ship canal was made. The policy of the railways with regard to the ship canal is instructive, especially in view of what 
may be their policy as to possible canal improvements in future. They first strongly opposed the Ship Canal Bill in Parliament, causing a large amount of money to be spent. Their opposition failed. They next reduced their rates so much between Liverpool and Manchester, knowing the canal would have to do the same, that the canal cannot earn any dividend. This was no doubt done to discourage further canal enterprises; but it is hardly likely permanently to stand in the way of what will be a great benefit to the country.

This is not the only case of the sort. The policy adopted at Manchester is part of a general policy of the kind. Some time before the Manchester Ship Canal was constructed, the River Severn was deepened and improved so as to allow steamers of four hundred tons to go up to Worcester; ; but the capital spent on the waterway has been rendered unremunerative by the railways lowering their rates sufficiently to obtain for themselves the traffic that would otherwise go by river. The traffic on the River Trent between Nottingham and the Humber has not yet received attention of this kind from the railways; perhaps because a sufficiently large amount of capital has not yet been laid out, or because further capital outlay will be necessary to make the navigation efficient.

Having regard to the influence of the railway interest, it now seems, on looking back to what has been done by Parliament, that something might with advantage have been done to enable canals to compete more freely for traffic. Some excellent opinions and principles were propounded $4 ;$ but sufficient steps were not taken to enable canals to be as useful as they might have been. Parlia- 
ment has controlled but has not guided, or at all events has not guided wisely, the course of events in the railway and canal world. In 1845 an Act was passed, owing to railway competition, giving canals power to become carriers, to vary tolls, and to make working arrangements like the railways. And an Act of 1858 prevented without legislative sanction the amalgamation of canals with railways, such as had been taking place under the guise of leases of canals by railways. In $1872 \mathrm{a}$ Joint Committee of both Houses of Parliament, after considerable inquiry, reported that harm had been done to free competition between inland waterways and railways by the purchase of important portions on the main water routes by railway companies. The Committee recommended that in future no inland navigation should be allowed to come under the control of a railway company; ; that compulsory purchase of canals from railway companies should be favourably considered by Parliament; and that the amalgamation of connected lines of inland navigations should be facilitated. An Act of 1873 provides that no. agreement between a canal company and a railway. company by which the railway would obtain control over the canal shall be valid unless approved by the Railway Commissioners, and that railwaycontrolled canals shall be kept in good navigable condition.

Excellent as are these recommendations as far as they go, very little has resulted from them. They were insufficient. As things have stood, up to now, probably few among the independent canal companies would have been willing to promote a Bill in Parliament for the acquisition of a railway- 
controlled canal. If opposed, as such a Bill usually, would have been, the cost would have been heavy, and the result doubtful. And the disfavour which, owing to misapprehension, has hung over canals for so long, may have deterred some companies from endeavouring to raise capital for the acquisition of neighbouring waterways.

In 1882 a Select Committee of the House of Commons was again appointed to investigate and report on the canal question. Not having completed its work when the Parliament of the time came to an end, it recommended that the Committee should be re-appointed : this recommendation was defeated, and consequently no report was made; but much useful evidence was taken.

In 1888 , in response to the wishes of traders, the Railway and Canal Traffic Act was passed. It regulates freight and toll rates, and provides for the periodical issue by the Board of Trade of a blue book of statistics relating to railways and canals. This Act does not contain any provisions for facilitating the recommendations of the Committee of 1872 , or for the improvement, enlargement, or amalgamation of canals. As a result a re-classification of goods was adopted, and toll and freight rates were revised, and for the most part lowered. This has done harm to some canals, crippling their limited efficiency by reducing already small revenues. This Act also provides that in the case of a railway having control of a canal, if the Railway and Canal Commissioners are satisfied that the charges for the conveyance of merchandise on the canal are calculated to divert traffic from the canal to the railway, the Commissioners, on the application of any person 
interested, may order that the canal charges be altered so that they shall be reasonable as compared with the charges on the railway.

Parliament has safeguarded the interests of traders in various ways. Railway and canal companies were given power to make lines which were partly monopolies and partly open to competition by sea and land, subject to rates charged not being higher than certain specified maximum figures. Improved appliances and the benefit of many kinds of modern economies enabled the railway companies to charge less than the maximum rates. Competition has also had an effect on the downward trend of freights. In the aggregate rates have come down to figures which, while apparently higher than many of the rates abroad with which they most nearly correspond, leave such small profit, and perhaps sometimes none at all, to the companies, that there is little, if any, real inducement to incur fresh capital outlay for such poor results. It must be remembered in this connection that it is very difficult, if not impossible, to make proper comparisons between British and foreign rates, because the conditions are different, and our rates in many cases include terminal charges, and sometimes the cost of collection and delivery, while foreign rates frequently cover no more than haulage from station to station. Not only have rates gradually been considerably lowered, but the partial monopolies originally conceded to companies by Parliament are in many cases much less of monopolies than they were, owing to competition of different kinds having been sanctioned by Parliament, or otherwise having come into existence. 
The outlook for the railways is in some respects not encouraging ; for their financial position as a whole is unsatisfactory, and makes impracticable large reforms which otherwise might be desirable. Their capital accounts are necessarily larger per mile than in many other countries, owing to land and other property being more valuable in largelypopulated countries than in newly-settled and thinly-populated regions. And capital accounts have been continually added to by expenditure which, though usually more or less necessary or desirable, cannot always strictly be called reproductive. It would have been wise to charge such expenditure against revenue. To add to the difficulties, the growth of some kinds of expenditure threatens the railway industry with consequences serious enough in some cases to cripple the standard of efficiency which now seems to be considered requisite. Increased local taxation and increased wages are two of the most serious items. The average amount paid per mile in local rates is about six times larger in Great Britain than in Prussia. Working expenditure is also high in this country ; large amounts are spent to ensure safety, in ways never undertaken in America and some other countries.

It is under these difficult circumstances that lower freight rates are still asked for-rates such as those in operation on routes in other countries where the conditions are different, and the cost of carriage consequently less than in the British Isles. It is difficult to see how railways can lower freights further : in the present state of things they cannot afford it. On the contrary, higher rates and fares seem justifiable unless working expenses can be 
reduced. Wages paid by the railway companies are apparently above the market value of the services performed, according to the statements made by one of the speakers at a conference of railway shareholders held in London on July 8, 1908. Much is heard of the demand for cheap freights ; but little is heard of the greater cost of transport in this country than in many others. As low freights as are practicable are most desirable; but it must be remembered that the price of the carriage of goods must chiefly depend upon the cost ; and the cost has to be paid for, whether the lines are owned by companies or by the State, as is the case in many foreign countries. Freights differ in different countries owing to different cost in varying circumstances. Advocates of cheaper freights in the British Isles sometimes speak as though they were unfairly treated by carrying companies because American or Belgian inland freights, for instance, or steamship freights, are lower than inland freights here. Such statements only show that they are not conversant with some of the factors of the problem.

In some countries State railways and canals, and in other countries private companies, make rates that seem low in comparison with rates in the British Isles; but such comparisons are of little if any value for the purposes for which they are frequently used, because circumstances that affect rates are different in different countries. Usually where freights are low compared with British and Irish freights the land for the route has cost very little; sometimes it has cost nothing; wages, except in America, are usually lower (but fewer hands are employed in America for the same 
work); rates and taxes are generally lower, and sometimes traffic is larger. All these things and some others are factors of importance which require to be properly taken into account when appraising rates. While the trade of the country as a whole is more important, because greater, than any single industry such as the carrying trade, the demands frequently made on this industry are far from reasonable. It has apparently become the custom with many people to complain of freights. There are other kinds of expenditure, made up of high charges and large profits, which business people pay, which might more reasonably be complained about, and which could more fairly be reduced than the cost of freight. There is as a rule little profit from freight. The carrying trade is worked at a smaller profit than most businesses, thus benefiting many other kinds of industry. The average dividend paid on ordinary stock of the railways of the United Kingdom is only about $3 \frac{1}{2}$ per cent. Even during periods of good trade the position and prospects of the railways can hardly be said to be appreciably better, for their large capital outlays and working expenditure seriously handicap them, and stand in the way of their being able to do better, unless the recent movement for diminishing competitive expenditure results in very considerable savings.

Lord Brassey recently stated, during the discussion of a paper read by Mr. Saner at the Institute of Civil Engineers, that at every congress of the Associated Chambers of Commerce, the Chambers all said they wanted to see the canal system improved. Other organisations have also shown 
great interest in the subject. Persons having most practical experience of inland waterways have expressed belief in their capacity for extended usefulness in this country. It is the commercial, manufacturing, and coal-mining sections of the community that are most interested in this matter : they are large constant users of railways and canals all the year round. Agricultural interests at times ask for cheaper freights ; but the benefits of canals to agriculture, and of agriculture to canals, are generally overrated, for agricultural traffic as a rule is seasonal and occasional, and is a comparatively small proportion of the whole traffic of the country. Even in a country so largely agricultural as France it is generally under , I 5 per cent, of the entire traffic, and some years little over to per cent. In this country, unfortunately, we have not yet adequate statistics which would show what percentage agricultural traffic bears to the whole traffic of the country, or other particulars such as are considered essential in some other European countries, and are really quite as essential here. An appreciable amount of the time spent by the Royal Commission in ascertaining facts could have been saved if we had adequate detailed statistics of the traffic of the United Kingdom-such, for instance, as are compiled in France. 


\section{CHAPTER III}

IS CANAL OR RAIL TRANSPORT THE CHEAPEST?

NUMBERS of persons who have good theoretical knowledge of the subject, and who are competent to form sound conclusions, believe that efficient canal transport, where the conditions are suitable, must be cheaper than transport by rail ; and business men who are considerable freight-payers are generally aware that inland water carriage is usually cheaper than that by railway. Although in numerous instances railways, owing to the superior facilities they offer, get traffic that otherwise canals would have, commercial experience generally is that canal carriage costs less. For instance, a director of Messrs. Tate's sugar refinery told the Royal Commission on Canals that his Company distributed sugar widely in England by both rail and canal, and that during five years the saving in freight averaged 14 per cent. by. using canals, where they existed, instead of railways.

The principal reasons why canal carriage is cheaper than that by railway indicate that if its capabilities are properly utilised it will be found 
cheaper-not everywhere, not in mountainous country, but where the conditions are suitable. The principal conditions necessary for canals, if they are to be successful, are that the route to be traversed shall not have differences of level that are too great, that there shall be a sufficient water supply, and that there shall be sufficient traffic. The reasons why canal transport is generally, cheaper than railway transport are convincing to many business men; but some think, apparently, that railway transport is the more economical of the two. To test the matter by looking to results is not as easy as might at first be supposed. Railway and canal companies' half-yearly accounts, while giving much useful information, do not give the particulars needed to make a comparison showing which mode of transport is the more economical. That is somewhat outside their scope. Their purpose is to give an account of work done during a given period. An experimental trial is sometimes a good way of testing rival merits; but in this case, however well planned and carefully conducted a trial might be, it could hardly, cover the whole field of varying conditions. It might not show much more than results such as could be obtained from selected train and barge services in daily running. The best way known of testing the matter is by an adequate system of ton mileage accounts, which shows the cost of transport per ton per mile; but railway and canal companies in this country do not publish such figures. Whatever ton mileage statistics, if any, are prepared for their own use are not generally. available. Although the system is not an absolutely perfect one, it is nevertheless the best 
method that is known for testing the economy of transport work. It is the best way of ascertaining in the aggregate which of two methods is the more economical. It is of use, too, in other ways, such as ascertaining by comparing the corresponding figures of different lines which items of expenditure are costing more, or less, per ton per mile on one line than another. In making comparisons of this sort allowance must sometimes be made, so far as possible, for varying circumstances and conditions peculiar to different routes; and, if the approximate values of different conditions can be arrived at, no other way at present in use will show the relative economy of different methods so well. But ton mileage figures, unfortunately, are not available.

For both kinds of inland transport, railway and waterway, three principal elements are required : the route, or permanent way; the vehicle, or vessel to carry the goods; and motive power. Under ordinary conditions that are as well adapted for waterways as railways, canal transport is more economical than that by railway with regard to the vehicle and the motive power, and with regard to the maintenance, but may not always be so as to construction of the line, although it usually is.

The cost of permanent way naturally must vary according to circumstances. It must vary with the nature of the country through which lines are made. The canal systems of Great Britain jost much less per mile than the railway system. The figures given in the Board of Trade returns show an approximate average cost per mile of about $£_{50,000}$ for railways, and the Royal Commission 
statistics '(which for 1908 take the place of the Board of Trade returns in respect of canals) show a cost of $£_{10,175}$ per mile for canals. Although these figures may be only approximately correct, owing to some canal capital being merged in railway companies' capital, and to sundry changes in capital accounts, the relative costs would probably. not be very materially altered if the exact costs were shown. It should be borne in mind in connection with these figures that were the canals as a whole developed and sufficiently well equipped for the requirements of to-day, the capital cost per mile would be higher. M. Krantz, in his report to the French Chamber of Deputies in 1874 , stated that French canals of average section had cost $£_{\text {I I }, 644}$ per mile, or about two-thirds the cost of an ordinary railway. Neither this figure nor the cost of the British canal system is a good guide for the present time, for the cost of labour is not the same now as when the canals were made, and the value of property is higher too. Of canals constructed in France in recent years the Canal de l'Est, 268 miles in length, cost $£_{4}, 000,000$, or $£_{14,925}$ per mile; and the canal from the Oise to the Aisne, 29 miles long, cost

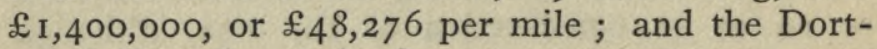
mund-Ems Canal, in Germany, cost $£_{25}, 500$ per mile. A fairer and better idea of the relative cost of railways and canals is to be obtained from the average cost of large systems which traverse various kinds of country than from the cost of particular lines; the figures given by M. Krantz are therefore of interest. But the cost of railways and canals varies greatly in different countries. British railways have cost about $£_{5} 0,000$ 
per mile, French railways about £27,000, German railways about $£_{20}, 000$, and those in the United States about $£_{\text {I I }, 000}$ per mile. Adequate modern barge canals in England would probably cost an average price per mile nearer to that of railways than to the original cost of the canals; but enlarging existing canals would cost appreciably, less, as shown by estimates given in evidence to. the Royal Commission.

The cost of maintenance of waterways is less than that of railways, because the wear and tear of materials, due to friction, is very much less on the former than the latter. The late Mr. Conder, M.Inst.C.E., in a report to Mr. Charles F. Clarke, of Wolverhampton, gives the cost of maintenance of way, works, and vehicles as about four and a half times greater on a railway than on a canal. The cost of maintenance of canals, according to the figures in the Board of Trade returns, is $£_{51} 3$ per mile, and the cost of railway maintenance was given as $£_{1,928}$ per mile by Sir George Findlay to the Select Committee on Railways, I $88 \mathrm{I}$.

As regards the vehicle or vessel used, ordinary, canal boats or barges cost less than the number of railway, wagons needed for carrying a similar. load. In other words, the vehicles for holding the goods cost more to construct and keep in repair for each hundred tons carried by railway than the barges or boats for each hundred tons carried by canal. And while average railway trucks usually weigh something like half or three-quarters as much as their loads, or even more, canal boats and barges usually, weigh only about a fifth or a sixth of their loads; a greater tonnage of non- 
freight-paying load has therefore to be hauled by the method which is the more costly of the two. On this point Mr. Saner, M.Inst.C.E., gave particulars in his evidence to the Royal Commission, showing that the first cost of the plant required to carry goods is less on a waterway than on a railway. And Mr. Lionel B. Wells, M.Inst.C.E., formerly engineer of the Weaver Navigation, stated to the Royal Commission that a railway train loaded with 220 tons cost $£_{3}, 360$ and a steam barge to carry the same tonnage $£_{1}, 600$. The steam barge can tow three barges, each carrying 200 tons, and each costing $£_{I, 000}$. The cost therefore of the steam barge and the three dumb barges is $£_{4}, 600$. Railway rolling stock to carry the same tonnage costs, Mr. Wells stated,

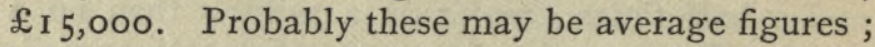
but even supposing improvements enabled the railway rolling stock to be produced somewhat more cheaply, the difference is rather too great for the comparison to be much affected.

Another matter of importance in relation to the vehicle or vessel used is that it is more economical to carry goods when the unit of conveyance is a large one : this is so especially with water transport. It is cheaper per ton to carry goods in large than in small quantities; and the advantage is greater on water than on rails, for the ratio of expenses diminishes in proportion as the load increases to a greater extent with water transport than rail transport.

The economy of large vessels is due to their being worked at less cost in proportion to their size than small vessels. The first cost of large barges is of course greater than that of smaller 
craft ; but in the case of a vessel or barge doing an adequate trade, the working expenses are a more important item of the entire expenditure than the interest on the difference between the first cost of one vessel and another. Doubling the size of a vessel or barge, thus largely increasing the earning capacity, does not necessitate doubling the number of the crew or the cost of propelling the vessel. For a vessel or barge of largely increased dimensions only a moderate extra expense is incurred for labour and motive power, consequently. the larger the vessel (within suitable limits) the smaller are the working expenses in proportion to the tonnage, and the cheaper therefore is the cost of carriage per ton. A 20,000-ton ship, for instance, pays better than two separate 10,000 -ton ships, because she needs less than two-thirds the crew and staff necessary for the two smaller ships, and she also uses less coal than would be used by. the two smaller vessels.

The cheapest mode of transport known to commerce is that by ocean-going vessels. It is cheaper than inland transport, partly because heavy, loads can be moved more easily on water than on land, partly because large vessels can be used at sea, and partly because the waterway costs nothing except for-works at the seaports. In the case of large ocean vessels the improvements in steam-engines [(the adoption of triple-expansion and quadruple-expansion engines, which have economised steam, and much lessened the amount of coal consumed) have contributed largely to the reduction of ocean freights; but triple and quadruple expansion engines are not economical when only a small motive power is required, and 
so would not be advantageous for ordinary canal barges.

The relatively small cost per ton of goods carried in the case of large cargoes explains why ocean freights are exceedingly low. Seagoing steamers carry goods at one-tenth to one-hundredth of average railway rates. It is obvious that equally low freights are out of the question on inland waterways; for the cost and maintenance of canals have to be paid for, and vessels as large as modern ocean steamers are impracticable on ordinary canals. Another factor that helps to make canal transport less economical than ocean transport is that more power is needed to move a load in a narrow channel than for the same load in a wide, open waterway. Greater motive power for the same load is needed in small channels than large waterways because the water displaced by the moving vessel cannot so easily escape in a restricted channel, and consequently offers more resistance to the advancing vessel. In open waters the water displaced by the vessel is pushed out of the way, with greater ease. For instance, a cargo steamer that travelled at about the rate of five miles an hour in the River Shannon above Portumna increased her speed to eight miles an hour on getting into the open water of Lough Derg, the other conditions being almost the same, there being a minimum of current in the river. This illustrates the well-known advantage of large, open waterways.

With regard to motive power, the cost is less on suitable waterways than on railways for the same load. Owing to the nature of things a load 
can be moved more easily, with less expenditure of power, and therefore more cheaply, on water than on land. This is partly because the resistance to be overcome is less in the case of a fluid substance like water than with hard, rigid materials like macadamised roads or iron lines of railway. The resistance is made up of three items: the resistance offered by the water that is displaced by the vessel, that due to the piling up of the water, and the friction between the water and the surface of the vessel. But for the purposes of the present argument the questions of resistance and friction, although interesting, need not be pursued further. No solid roadbed nor any mechanical arrangement appears able to rival the natural advantages of the small frictional resistance offered to a load passing through or over water. For the transport of goods this inherent element of cheapness apparently cannot be excelled-at any rate, not in the present state of engineering scienceand there hardly, yet appears much prospect that it is likely, to be. Owing to the small resistance offered by. water to a moving load, not only is the movement of a vessel effected with less power than on road or rail, but the injury, the wear and tear, to the materials used is less, and the cost of maintenance and repairs is therefore smaller. $\mathrm{Mr}$. Bartholomew, M.Inst.C.E., for many years engineer and manager, and now a director, of the Aire and Calder Navigation Company, stated to the Royal Commission that with low speeds the resistance increases very, little when the load is increased. The late Mr. Conder, in the report already referred to, puts the cost of traction on canals as only, half that on railways. He states 
that the force that will draw a load on a canal four miles an hour is half that required to draw an equal load on a railway at thirty-five miles an hour. Another authority states that the same amount of power applied in traction will move five times the load on a waterway that it will on a railway. While four miles an hour is a good speed on a canal, speed is not the most important matter for most classes of goods that are carried on inland waterways. It is the cost of freight, not the speed, that is all-important for most goods and mineral traffic. In small countries, such as Great Britain and Ireland, it is not altogether unusual for goods to be delivered as soon, or nearly as soon, by. canal as by railway, owing to the comparatively short distances that have to be traversed, and the congestion of traffic which sometimes causes delay. on busy railways. With the bulk of the heavy traffic, the cost of freight is of more importance than the time occupied in transport. The time of transport being known, goods are generally, or can be, ordered sufficiently long before being required to insure their delivery by the time they will be wanted.

The great practical advantage possessed by canals over roads was soon realised and appreciated by our ancestors when they found that a horse could draw a much greater load on a canál than on a road. It was an obvious advantage for a horse that could draw a ton on a road to be able to draw twenty-five tons or thirty tons if the load was floating on water. Subsequently with larger waterways it was found that a horse could do more than that. One authority states that the most a horse can draw on a level road is from 
one to two tons, from five to ten tons on a tramway or railway, and from fifty to eighty tons on a canal. These figures may be taken approximately, for on an efficient modern canal (i.e., a canal of adequate cross section) a hundred tons can be drawn by one horse, as is done on the Aire and Calder Navigation, and on the Weaver. And on some of the larger continental canals a horse could under favourable circumstances draw more than that. Loads of two hundred and fifty to three hundred tons are hauled by two horses on some continental waterways, and loads of two hundred tons by two horses on the Weaver Navigation.

Any one having doubts as to the small amount of motive power required to move a load on water, compared with that required to move the same load on rails, can satisfy himself either by consulting some good work of reference or by an experiment, such as moving an empty truck on rails, and then moving on a canal a boat or raft loaded so as to make the total weight to be moved the same as in the case of the truck moved on rails. Whoever tries this experiment will find that a load on water can be moved much more easily. (with less power, and therefore at least cost) than a load of equal weight on rails. Although these things are well known to many engineers, and to persons conversant with matters of the kind, they have been very generally overlooked by business men, and their bearing on the freight question as been little realised in this country.

Notwithstanding the disadvantages that inland waterway transport is under in comparison with ocean transport, two or three causes which operate to make sea freights the cheapest that are known 
(viz., the cheap average cost per ton of motive power when it is used on a large scale, and the low cost per ton of large cargoes) operate, although in a smaller degree, yet sufficiently to make inland waterway transport cheaper than any form of land transport in parts of the country that are suitable for canals.

On well-constructed modern waterways larger loads than those carried on average English canals are carried at only slightly larger cost per barge load, for the reasons already given. For example, a barge carrying 50 tons would cost, on some canals, about $£ 6$ per week for wages and horsing expenses. On a larger canal of sufficient capacity to allow a barge carrying 100 tons to travel at the same speed as the 50-ton barge travelled, the same crew would work the I0o-ton barge at about the same out-of-pocket working expenses as the 50-ton barge. The additional costs incurred would be the value of the time taken in loading and unloading the additional 50 tons, the proportion of extra cost of maintenance of the larger barge, and a slight addition to wages on account of the larger tonnage to be loaded and unloaded. This last item would perhaps not be reckoned in cases in which the barge was worked by the owner and his family. The additional cost incurred in respect of the 100-ton barge would amount, as will be seen, to very little. The net result would be that 100 tons would be carried for little over the aggregate amount it cost to carry. the 50 tons; so that the rate per ton with the roo-ton barge would be little more than half the rate per ton with the 50-ton barge. With 200ton or $300-$ ton barges the same principles apply, 
and the amount of reduction in the rate per ton would work out proportionately greater. Where traffic was sufficiently increased by cheaper freights for receipts from the extra traffic to pay interest on the cost of enlargement of the canal, no charge on this account would fall on the roo-ton barges in the shape of increased tolls, but otherwise some increase might be necessary. It follows that the larger canals can be, within suitable limits, having regard to the amount of traffic, the cheaper will be the cost of freight. Increasing the load to an equal extent on railways as on canals can only be done by increasing expenditure in a greater ratio than is the case with canals. It is not only. the cost of motive power that increases more rapidly with the increase of load on railways : the cost of maintenance increases more or less proportionately to the increase of tonnage, while on canals the increase of tonnage has so little effect on the cost of maintenance, that it is hardly. appreciable on some canals where a largely increased traffic is dealt with. This, of course, is owing to the greater amount of friction in connection with railway than waterway traction, the friction causing constant wear and tear. "It was shown long ago " " "that the proportional cost of engineering (locomotive repairs and maintenance expenditure) on ten of the principal English railways rose in a ratio of about $\frac{1}{2}$ per cent. of gross revenue for every additional I per cent. of gross revenue which is derived from mineral traffic. Thus, while these expenditures (maintenance, locomotive, and repairs) were about I6.09 per cent. of revenue on the Metropolitan Railway,

${ }^{2}$ Inst. Mech. Engineers, vol. ii., p. 192. 
which got 2.36 per cent. of its revenue from minerals, they rose to 36.32 per cent. on the NorthEastern Railway, which got 37.I I per cent. of its revenue from minerals." These figures show how largely the cost of maintenance is increased by wear and tear caused by traffic, and especially by heavy traffic.

It is true that canal freights in the United Kingdom are generally but little lower than the corresponding railway freights:; some are the same, and many are only about 5, Io, or I 5 per cent. lower; but this is because most of the canals are primitive and inefficient for present-day requirements, while the railways are highly developed and well equipped. It is as unfair to compare old canals with modern and efficient railways as it would be to compare a locomotive of sixty years ago with a new one of the present time. In many instances rail freights are as low as canal freights, not because the railways can really afford to carry so cheaply, but because the railway companies reduce their rates to the level of canal rates in order to obtain the traffic. Apparently they look at the matter in some such way as this : that without any very obvious addition to working expenses they thus get some additional revenue which appears to be almost all extra gain. But where the costs per ton per mile of maintenance of way, of traction, and of rolling stock maintenance are not calculated, it cannot be known what the actual expense of carrying each extra ton amounts to ; and it must, therefore, be impracticable for companies to know whether certain rates are remunerative or not.

Were those British canals which have sufficient 
present and prospective traffic to justify it reconstructed so as to be capable of accommodating larger barges, freights on them would of course be lower. Explanations given in the previous pages show that this would be so. Actual results on the Aire and Calder Navigation and other improved waterways corroborate it. The fact that freight rates on efficient inland waterways are a cause of railway rates being lowered also shows that waterway transport is cheaper than rail transport. If efficient waterway transport were not cheaper than rail, this would not be so.

On the Aire and Calder Navigation some of the lowest inland freights known are in operation, owing to the efficiency of the waterway. Mr. Bartholomew, M.Inst.C.E., stated in evidence to the Select Committee of the House of Commons on Canals in 1883 , that .03 of a penny per ton per mile was the average cost of transport on the Aire and Calder waterway; the cost on the Leeds and Liverpool Canal was given as .30 of a penny per ton per mile; that on the Grand Junction Canal was stated to be .35 of a penny per ton per mile; and on a railway-controlled canal between London and Birmingham it was stated to be 1.40 of a penny per ton per mile. These figures are useful as showing that the average cost of transport on one of the only two enlarged modernised inland waterways in the British Isles was, at the time mentioned, only about one-tenth of that on two of the old unenlarged canals; and it is about the same still; but it is only fair to remember that the physical conditions in the case of the Grand Junction, and Leeds and Liverpool Canals are not so favourable as with the Aire and Calder Navigation. 
The following figures were also given by $\mathrm{Mr}$. Bartholomew before the same Committee :

Cost of Haulage on Aire and Calder Navigation. 1883.

By steam tugs carrying cargo and towing $\quad \ldots \quad \quad \ldots \quad \ldots \quad \quad \ldots \quad$ I-2gth of a penny

By steam tugs only (on 2,250,000 tons) $\quad \ldots \quad \ldots . \quad \ldots \quad \ldots . \quad$ r-7th $\quad$,

By horse haulage (on 650,000 tons)... I- $5^{\text {th } ~ " ~}$

By tugs with trains of tank barges (coal traffic) (on 5,500,000 tons) I-I Igth "

Although these are the figures of a quarter of a century ago, they are of much interest. They show a degree of efficiency unexcelled, I believe, in this country except on the Aire and Calder waterway itself in subsequent years. The late Mr. Conder, M.Inst.C.E., estimated the cost of transport on English canals generally at .36 of a penny per ton per mile. He included interest on an estimated capital cost of $£_{\text {I } 5,000}$ per mile, and included the cost of boats, traction, interest, maintenance, and returning empties.

To the Royal Commission on Canals now sitting Mr. Bartholomew gave the present cost as follows :

Cost of Haulage on Aire and Calder Navigation :

$$
\text { I907. }
$$

$\begin{array}{lllll}\text { By steam tugs ... } & \ldots & \ldots & \ldots & \text { I-29th of a penny }\end{array}$

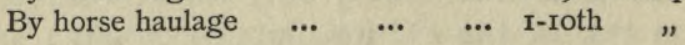

The steam-tug haulage is for an express service : it would be lower for heavy traffic needing a slower speed. The cost of hauling coal in the tank barges remains about the same as in 1883 
(I-IIgth of a penny per ton per mile). The low cost arrived at on this waterway for the carriage of coal is probably about the lowest of inland freights yet reached, unless in the case of some of the freights on the great lakes of America, where, however, the conditions are virtually those of ocean transport.

As far as I know, there are no English railway figures to be had corresponding with those given by $\mathrm{Mr}$. Bartholomew showing ton-mileage cost of traction. It would be interesting and useful if ton-mileage costs could be produced including the items corresponding with those on which $\mathrm{Mr}$. Bartholomew's calculations were made, and any others that should properly be included, showing the actual cost of traction per ton per mile, in the case of the Lancashire and Yorkshire Railway Company's goods and mineral trains which compete with the barges and floating coal compartments of the Aire and Calder Navigation Company, or which travel about a similar distance in the same part of the country. Each company. carries about a million tons of coal per annum from collieries adjacent to its line to the seaport of Goole, as well as a large tonnage of other traffic in both directions. The waterway carries the coal referred to at about twopence per ton lower than the railway. The freight on coal carried by rail from South Yorkshire to the seaports is stated to be about 35 or 40 per cent. of the selling price, while it is only 25 per cent. of the selling price of that carried by the Aire and Calder Company. Goods and merchandise are carried by the Aire and Calder Company, at about a penny in the shilling, or between 8 and 9 . 
per cent. less than the railway rates. The railway rates here mentioned are lower than ordinary railway rates. Both companies are steady-going ones, earning and paying somewhat similar moderate dividends. This appears to be about as fair a test case as could be found in this country : there does not appear to be a fairer or better one : the comparison appears reasonable. It would be better still if the ton-mileage cost of freight, instead of traction only, could be given by both companies. The main conditions are tolerably similar. Favourable physical conditions exist for each method of transport; each line traverses somewhat similar comparatively level country. This must have kept down the capital cost for both; and the absence of severe gradients on the railway and of frequent locks on the waterway favours moderate working expenses. Each has a sufficiently large traffic to enable work to be done economically. The waterway as well as the railway has the advantage of having been improved and equipped in accordance with modern engineering knowledge ; and from a commercial standpoint the water route is as efficiently handled as the railway.

Railway men sometimes allege that the Aire and Calder and the Weaver Navigations are exceptional cases that ought not to be taken as indicating, in a general way, the capabilities of inland waterway transport. But these waterways are only exceptional really in the sense that there are no other barge canals of equally large capacity in this country. They are not exceptional in showing the economy of improved inland water transport. They coincide with inland 
waterways of somewhat similar capacities abroad in showing the economic advantages of waterways of adequate dimensions. It is true that the contour of the country through which the Aire and Calder Navigation passes is favourable for water transport, few locks being needed. But there are other canal districts which also have favourable physical features. Had canals in those districts been so fortunate as to have men like Mr. Bartholomew connected with them, probably there might have been some other waterways in England as efficient as the Aire and Calder. The existence of considerable differences of level between the upper and lower portions of the River Weaver did not deter Sir (then Mr.) E. Leader Williams and his board of trustees from proceeding with their great improvements on that river. In view of results of a similar character to those obtained on the Aire and Calder having been arrived at on the Weaver Navigation and on numbers of canals and river navigations in other countries, it cannot be seriously maintained that the success of the Aire and Calder Navigation is due to exceptional causes which would make similar successes unattainable elsewhere. It may be said that this waterway is partly composed of natural rivers which cost little or nothing for construction originally, and that freight therefore should be cheaper than rail freight. This, however, is counterbalanced by the railway having passenger traffic, which the waterway has not, and further to some extent by the cost of making the rivers increasingly navigable and of dredging and maintaining them. The case of this Company shows that when a waterway situated where there is adequate traffic is suitably 
enlärged and well equipped, goods arē profitably carried at much lower than ordinary railway rates.

Results of course differ in degree; but, as might be expected, it is the general experience in other European countries that have good modern waterways, as well as on the Weaver and the Aire and Calder, that freights on large canals and canalised rivers are so cheap that the waterways usually attract the bulk of the traffic where they. compete with railways on anything like fair conditions. Figures showing the average cost of transport per ton per mile of goods and minerals on both railways and inland waterways in the United Kingdom would be the best means of stamping with arithmetical certainty the conclusions indicated in this chapter. 


\section{CHAPTER IV}

\section{RAILWAYS VERSUS CANALS}

IN the previous chapter it is shown that where the conditions are suitable inland waterway transport is cheaper than railway transport. Proof in the shape of ton-mileage cost of each mode of conveyance is not available, as explained. But the reasons why it is so and an instance of a good test case are given. It may naturally be said in reply: If canal transport is the cheaper of the two methods, why do not the railway companies, the largest carriers in the country, use canals, especially their own canals? The question is one that cannot be answered categorically.

The railway view of the matter may be partly gathered from the evidence given by railway, representatives to Parliamentary Committees and Royal Commissions. At meetings of the Associated Chambers of Commerce resolutions advocating canal improvement have frequently been discussed and approved of by majorities of those present ; yet railway men at these discussions meet the resolutions with silence, as the official reports of the meetings show. No declarations on the subject, nor any explanations of their canal policy, appear to have been given by railway chairmen. 
Nor does any explanation of railway canal policy. appear to be asked for at half-yearly meetings. Shareholders presumably accept the railway attitude in the matter. Railway silence as to canals appears to be broken only when a Parliamentary. Committee or Royal Commission takes evidence. on the subject. Some traders then usually give evidence that is more or less unfavourable to the canal policy of the railway companies; and evidence of this kind is generally met by statements as to the position of things from their point of view by railway managers and engineers, whose opinions are not usually favourable to canals. Both sides, however, are cross-examined by. members of the Committees and Commissions.

In addition to this official information there are the writings of a couple of authors who advocate railway views and are unfavourable to canal transport. Mr. W. M. Acworth, M.A., a barrister, is one of these; and the other, Mr. E. A. Pratt, is the author of a book entitled "British Canals : is their Resuscitation Feasible?" Railway representatives agree in approving of railways and condemning canals ; but their expressions of opinion can hardly be taken as unbiassed. As, however, railway opinion on the canal question is not often heard, and seems never to be very fully explained, it is of interest to examine it at some length when opportunities occur.

Mr. O. R. H. Bury, general manager of the Great Northern Railway, gave evidence to the Royal Commission to the following effect : He thought canals no longer serve a useful purpose; that railway companies have complied with their obligations, and have kept their canals in proper 
order; that railways lose money by canals, and are unable to see any way of lessening the loss. The Great Northern Railway lose $£_{3} 0,000$ a year by their canals. Canals were, he said, forced on railway companies, or the canal companies sold their canals when they believed the railways would ultimately take their traffic. Parliament practically said to railways, "If you make that railway, you must buy the canal as well." Railway. lines, he continued, have been improved because there was demand for it, but there was no. demand for canal improvement.

Sir Frederic Harrison, the late general manager of the London and North-Western Railway, stated to the Commission that he considered canals obsolete as a general means of transport on account of rapid conveyance being desired. He did not consider increased facilities would increase the use of canals; any benefit the trade of the country would derive from improved canals would, he thought, be incompatible with the cost. He considered that railways could compete successfully with canals, but did not desire the suggested further canal competition.

Several of the railway representatives stated in their evidence to the Commission that there is a tendency for consignments to become smaller, and to be more frequently ordered, and that railways only, and not canals, can deal satisfactorily with this state of things.

Sir Frederic Harrison said that trade being conducted on more retail lines than formerly is an element of increasing difficulty in the position of canals. The evidence he offered in support of this opinion was that the average weight of each 
package was 2 qrs. I 6 lbs., and the average weight of each consignment was 3 cwt. 3 qrs. 22 lbs. at the London and North-Western Goods Station at Broad Street, London, E.C. But a good deal of traffic of a somewhat retail character is to be expected there; for it is close to those parts of the city where drapery, fancy, and miscellaneous small wares are supplied by wholesale traders to retail traders all over the country. The average weight of consignment at all the Company's goods stations would, no doubt, be considerably higher.

It was stated, too, by railway managers that traders, in order to work with less capital, keep small stocks, and so need small quantities constantly sent on to fill gaps caused by sales. No doubt that is so in some trades, more or less; but in other kinds of business traders supply, themselves, as far as is practicable, when market prices are low. The suggestion that only the railways can deal with small consignments is very far from correct. Traffic of the sort is carried on well-equipped, well-managed canals where there are adequate barge services-where, in fact, traffic is dealt with in a businesslike way.

The coal traffic was also spoken of by the railway representatives as capable of being better handled by railways than canals. The railways certainly have the lion's share of this traffic, a fair proportion of which might be expected to be found on the canals. Heavy traffic of low value in proportion to its weight, traffic which cannot afford to pay the cost of quick transport, is particularly suitable for the slower, cheaper mode of conveyance. It was pointed out that some of the collieries are too high up for the canals to get to 
them, while railway sidings are able to go to the pit's mouth; and that small lots, such as truckloads, are more convenient to coal merchants and buyers than large consignments, such as boatloads.

With regard to the first of these points : while there are numbers of collieries out of reach of canals there are also collieries in touch with canals; but the question of proximity to waterways is not peculiar to the coal traffic; and it is quite true that canals are not always in locations to suit collieries. But where efficient waterways reach collieries they are capable of carrying coal more economically than railways. As to truckloads being more convenient than boatloads, that applies as a rule more to house coal than coal for manufacturing and trading purposes; but there is little in the argument where the facilities are good, and where the cost of loading and unloading is small. Where canals provide good facilities and businesslike organisation, they can generally suit the requirements of the coal trade as well as the railways, and they do so in various instances. The railways have the bulk of the inland coal traffic in Great Britain, largely because they have provided the requisite facilities ; but if improved canals were provided with good facilities, as on the Aire and Calder Navigation, and they had a sufficiently large tonnage, they would have an advantage over the railways as they could carry more cheaply; and if good loading and unloading arrangements were made, the coal would be less broken owing to the absence of wagon-shunting. With regard to collieries in canal districts at too great an elevation to be profitably reached by canal, in some cases no doubt 
the coal could be sent down to the canals by the Lancashire plan of tubs on endless chains, or by aerial wire tramways. Bricks and other heavy. traffic are conveyed in this way at various places. Sir Frederic Harrison's opinion that canals are unable to compete successfully with railways for coal traffic, if applicable to some of the old, unimproved, narrow canals in England, whose locks are only seven feet wide, is hardly tenable in the case of canals of adequate size having competent business organisation.

Mr. Bury put bricks in the same category with coal. He said they are handled in quantities more convenient to traders by the railways than by the canals. The same answer applies to the brick traffic as to the coal : with proper equipment and good business methods the convenience of buyers can generally be as well suited by canal as by railway. Mr. Bury's point, that buyers often want small lots of coal and bricks that can be handled and distributed at once without incurring the cost of storage or stacking, does not necessarily involve rail transport. Canal boats and barges are quite capable of carrying small lots, and do so on some independent carrying canals. Mr. Bury seemed to imply that this could only be done by railways.

Mr. T. H. Rendall, goods manager of the Great Western Railway, told the Commission that coal traffic pays because full loads are to be had, and because of the large quantity carried. Though rates seem low, it must be remembered that the railways generally do not load or unload coal, and that they charge wagon hire as well as freight; and they get a comparatively long haul for much of the coal traffic, which helps to make it re- 
munerative if the freight is not too low. But without adequate ton-mileage accounts it cannot be satisfactorily ascertained what profit the coal traffic really gives. It is an important item of traffic because of its large volume; but little additional light has been thrown on the matter at issue by the evidence given to the Royal Commission.

Messrs. Fellows, Morton, \& Clayton, Ltd., the largest firm of canal carriers in the United Kingdom who are not canal owners, carry very little coal. This can be easily explained. The railway, freights for coal are low, and Messrs. Fellows, Morton \& Co. prefer to carry merchandise that pays better. If, however, a large enough part of the tonnage of coal carried to London by rail was carried by canal, it would be worth while for the canal company or the canal carrier interested to provide facilities similar to those on the railways. In that case this traffic could be carried at a low freight-how low would depend on the size of the canal and other conditions. Messrs. Fellows, Morton \& Co. carry heavy goods more cheaply than the railways, and are able to maintain their position in competition with the railways, although they carry in some districts that have rather numerous locks.

Mr. S. Fay, the general manager of the Great Central Railway, told the Royal Commission that he thought the greatest proof of the superiority of the English railway goods service as compared with the waterway service was shown by the large volume of traffic passing by rail between manufacturing districts close to ports where there is sea competition. Speed, he said, was the great 
factor against canals. When asked during crossexamination if there was not a large amount of traffic in this country which does not require high speed, he replied, "I have not met any." When asked if there was not a large amount of traffic that can bear slower transit than that by railway, he answered, it might be able to bear it, but he did not know whether the public would appreciate a lower rate of speed. Then he admitted in another reply that in some instances he had no doubt that if traders can get a lower rate of freight they will be content with a lower speed. Asked if coal might not go slower, Mr. Fay said, "Not for export," although earlier in his examination he had stated that coal was sent on to seaports to await orders, and that it had sometimes waited in wagons six or seven months for better markets. He next replied that the small water space for barges limited the development of canal traffic which waited in docks for steamers, but had to admit in answer to further questions that there is a large amount of traffic waiting in barges for steamers in Liverpool, that the centres of the docks were not full at all times, and that there is always plenty of space for these barges and room for expansion.

Another railway view put forward was that railways suit traders best; and that in spite of higher rates traders prefer to send their goods by rail instead of canal. Mr. Grierson, of the Great Western Railway, made a statement to this effect to the Royal Commission. In the present state of many English canals it is no wonder that frequently this is so. Owing largely to railway policy many canals do not offer as good facilities as the rail- 
ways. Many of them have not the equipment or organisation to enable work to be done in a business-like way. Perhaps a sufficient answer to the statement that traders prefer railways to canals is that the Associated Chambers of Commerce, the most representative body of traders in the country, have repeatedly passed resolutions in favour of canal improvement.

Then railway representatives say that canals can never compete with railways in the matter of speed, as though that settled the question. Mr. Fay told the Royal Commission that speed " is the great factor in the whole thing." Latterly railway men seem to have thought it expedient to give prominence to the argument as to speed. Railway managers apparently have decided that quick transport is the thing that freight-payers most need. They supply quicker goods services than formerly, which are perhaps calculated to cause dissatisfaction with the speed of canal transport. Mr. Saner in his paper read before the Institution of Civil Engineers in 1905 referred to goods being delivered in Cheshire from London as soon by canal as by railway. The comparatively slow delivery by rail at times is said to be due to congestion of traffic. Railway representatives say that goods handed in one day are usually delivered in northern England the next. The railway companies apparently would like to see speed regarded as more important than cost of transport-a more than doubtful proposition for ordinary goods traffic. It was pointed out to Mr. Fay at the Royal Commission that this alleged demand by traders for quick transport which is put forward by railway men has apparently no 
counterpart in the continental countries which have a very large traffic on their waterways, where the distances are greater. Mr. Fay replied that there was probably no demand for quick transit on the Continent; and that the railways there were allowed by law two days for receiving and forwarding goods to enable them to get full truckloads and full train-loads. This would help them to carry rather more cheaply than otherwise ; but it does not support the view that rapid transport is of value for ordinary merchandise. The objection that canal transport is useless when goods are wanted quickly is not altogether correct. The difficulty is got over by merchants and manufacturers having agencies, warehouses, or stores at various places through the country. Customers are supplied at once from these, and the stock at these agencies is replenished by canal. Coal, beer, flour, sugar, oil-cake, and such like commodities are supplied in this way. Messrs. Guinness in Ireland, and Messrs. Tate, the sugar refiners, in England, for instance, adopt this plan.

The foregoing pages convey (I think fairly) the general tenor of the arguments used by railway representatives with regard to controversial parts of the question. But time brings changes; and some of the railway spokesmen apparently, along with the rest of the world, have got somewhat beyond the old attitude of mind with regard to canals. Some of them adhere to old views; others, while more or less upholding the old ideas, admit some of the views of canal advocates. That modern inland water transport in suitable places is more economical than any form of land transport is now generally allowed by unbiassed 
persons who know the facts : and it is satisfactory to find that Mr. S. Fay, of the Great Central, and Mr. R. Millar, lately of the Caledonian Railway, have virtually implied, if not admitted to the Royal Commission, that inland waterway carriage is, or can be, in some circumstances, more economical than railway carriage. $\mathrm{Mr}$. Millar replied in answer to a question, "Of course it" (canal carriage) " must be cheaper." Mr. Fay, after being questioned by Lord Shuttleworth, the chairman of the Royal Commission, about the Sheffield and South Yorkshire Navigation Company, was next asked, "Has it been recognised as a principle that canal rates should be lower than the railway rates?" $\mathrm{He}$ answered, "Yes, we have always recognised that would be so." That appears to refer to the canals of the Sheffield and South Yorkshire Navigation Company. It seems practically equivalent to agreeing that canal carriage is less costly than railway carriage. At least, it is difficult to put any other construction on Mr. Fay's reply. These admissions go some way towards endorsing the contentions of canal advocates, and they are made by those representing the railway interest, which is virtually the only interest opposed to canal development.

Mr. W. M. Acworth, in the Economic Journal of June, I905, states (p. I50): "I submit as a broad proposition, and ignoring exceptional cases that must always exist, that the evidence shows that there is no traffic which can be carried on a barge canal as economically as a railway. Therefore to spend money on canals implies economic waste." The conclusion I draw from the evidence is the reverse of that above 
stated. Others must judge as to which conclusion is the more correct one.

Mr. Acworth states (p. I 50) with regard to the charge that has been made against the railways of "strangling" the canals: "No specific instances are given, so they cannot be investigated." Elsewhere on the same page he says : "Instances of the strangulation process are never forthcoming." The expression " strangling " is, of course, used metaphorically. It is, perhaps, not the most applicable that might have been chosen, but it came into use, and those familiar with this subject know what is meant by it. Mr. Acworth is hardly correct in stating that no specific instances of "strangling" have been given. Any one as conversant with the subject as he appears to be might be expected to be aware that what is meant by "strangling" in this connection is doing things that hinder, obstruct, or stop the natural flow of traffic on inland waterways. Various instances of things of the kind, which $\mathrm{Mr}$. Acworth appears to have overlooked, were given by witnesses to the Select Committee on Canals, I 883, and to the Royal Commission now sitting, and, I believe, at other public inquiries. As, however, he alleges that no instance has been given, one may be mentioned. Mr. L. Foster, chairman of the Ouse Navigation Committee, York, gave evidence to the Royal Commission on Canals (I906) that on the Derwent Navigation tolls on coal from Derwent Mouth to Malton were formerly fourpence per ton, and that when a railway company acquired the waterway they gradually raised the charge to $2 \mathrm{~s}$. $8 \mathrm{~d}$. per ton. That is an instance of what traders call "strangling " water- 
way traffic. The higher tolls per mile charged in numbers of cases on railway-owned canals than on independent canals is one of the things so characterised, because it is one of the ways in which the railway companies are considered to have squeezed the life out of canals. This was virtually admitted by one of the railway spokesmen before the Royal Commission, as mentioned on another page. High tolls on railway-owned canals often affect not only the traffic that begins and ends on these canals but through traffic from other canals. Closing their canals for the night, thus delaying traffic, or preventing it from appearing at all, is another method which railway companies have adopted that "strangles" canals and canal traffic. The statement by the engineer of the Lancashire and Yorkshire Railway Company to the Royal Commission that that Company closes at night its Manchester, Bolton, and Bury Canal serves as an instance. It will do for another instance for $\mathrm{Mr}$. Acworth. The independent canals are, of course, open during the whole twenty-four hours on weekdays, as canals need to be; for the slower method of transport requires to lose no time when competing with railways. The fact that a Parliamentary Committee recommended that railway companies should not be allowed any new control of canals, direct or indirect, shows that the opinion was accepted that railway companies were directly or indirectly controlling or interfering with canals or canal interests in ways that the Committee thought undesirable. If the railways had been satisfied as to the superiority of their own means of transport, if they believed it to be more economical than canal transport, 
would it not have served their purpose to let their system of transport depend on its merits without adopting the various measures that have been roughly characterised as strangling?

Mr.Acworth asks (p. I 5 I): "But what interest has the Great Western in diverting traffic from the Kennet and Avon Canal? It owns both railway and canal. It may as well make its profit on one as on the other. If canal carriage is naturally cheaper, there must surely be a larger margin of profit to the railway company in carrying by the canal." Although the question and the argument following it are of an ironical character, I will take them seriously. A comparatively short canal, less well equipped and with less extensive connections than a large railway, can hardly be expected to be as profitable. Doubtless, the Great Western Railway consider it to their interest to divert traffic from the Kennet and Avon Canal to the railway, because it is more convenient to work one large, well-equipped system of transport than to do the same work by means of one large system and one small, less well-equipped system. The Company has continually made the railway. as efficient as possible, but has not done so with its canals; the canal in question has therefore no chance of being as useful or profitable as the railway.

Mr. Acworth (p. I 52) says that the statement that canal traffic in France and Germany has increased in recent years faster than railway traffic is partly true, but wholly irrelevant if used to show the inherent superiority of canals; for the increase is on the great rivers; and Cologne, Frankfurt, Berlin, and Paris have been made into 
ports accommodating vessels of $\mathrm{I}, 000$ tons. It is difficult to see why in the case of canals whose traffics have increased faster and faster than those of the neighbouring railways this should be regarded as " wholly irrelevant if used to show the inherent superiority of canals." My experience, perhaps particularly in Germany, is that those conversant with matters of this kind have no doubt at all as to the canal traffic increases being mainly due to the inherent superiority of canals. It is true that continental canals are mostly tollfree ; instead, however, of this giving canals much advantage over railways, it is more or less counterbalanced by the railway having passenger as well as goods traffic, and a more extensive area from which to obtain traffic. Mr. Acworth says the statement that canal traffic in France and Germany has increased in recent years faster than railway traffic is partly true; he refers to the traffic increase on the great rivers, and he refers to the inland waterways of four continental cities having been made navigable for vessels of $\mathrm{I}, 000$ tons. Each of these things is testimony to the value of navigable inland waterways. The great expense incurred to make the waterways referred to suitable for 1,000-ton barges would never have been undertaken had not inland waterway transport been found to be more economical than rail transport.

Railway men in both France and Germany, Mr. Ackworth states (p. I 52), assert they could get back the traffic from rivers and canals if they were allowed to put in force competitive tariffs. The Western Railway of France, he continues, would gladly make exceptionally low rates between 
Havre and Rouen and Paris. But the Government refuses permission unless the same rates "are applied all over the system." "To do this," Mr. Acworth continues, "would send the railway company into bankruptcy." The last two observations of Mr. Acworth's are not a bad commentary on the matter. They remind us that French as well as English railways are desirous of obtaining traffic from the waterways by means of low competitive rates, and that the French Government does not allow injury to be done to waterway transport by unfair competition. Mr. Acworth concludes this matter by saying: "So the railway rates are kept up and the traffic goes by water." . . " A strange commentary on the oft-made assertion that water carriage does not compete with but supplements railway carriage." $\mathrm{He}$ does not say where he quotes from : few, however, who discuss this question would assert that water carriage does not compete with railway carriage. But while water carriage frequently competes with railway carriage, it also supplements it, and has done much to increase railway receipts by enabling industries to be successful which could not have been carried on if raw materials had not been carried by waterways at lower rates than are profitable by railway. By this means districts get additional commerce and prosperity from which the railways derive increased revenue both from goods and passengers, which they would not have at all if cheap waterway carriage had not made industries practicable. This is what has been heard repeatedly from German delegates at International Canal Congresses.

Mr. Acworth says (p. 153-all my quotations 
from $\mathrm{Mr}$. Acworth are from his article in the Economic Journal of June, I905) that the experience of the United States should be of value to us. I agree with that opinion. He then gives a brief sketch of the position of things as he sees it, which, however, is somewhat misleading, as it does not reveal the actual position or the influential part played by the waterways. He states that the Mississippi, on the improvement of which the United States have spent many millions, is dead as a competitor for traffic. Now while it is true that the railways have captured most of the traffic such as used to go by the great river, the waterway is very far from dead as a freight regulator. The Mississippi is a vital factor in this respect, railway rates being regulated under the influence of the fact that a competitive waterway route is still in existence, and would again quickly become active if railway rates were raised to anything like the old levels. The waterway, therefore, instead of being dead, is a powerful factor in keeping rail freights in check.

Of the famous Erie Canal, Mr. Acworth states (p. 153): "Its traffic has decayed till it has become a negligible factor in the total trade. New York, being persuaded that their city and State were losing traffic because the railways had strangled the canal, have recently voted by a referendum to spend $£ 20,000,000$ on bringing it up to date. But so satisfied were the railway. managers that they could profitably carry traffic at rates which the canal could not touch, that not only did they refrain from opposing the passage of the Bill, but they did not care even to undertake what is called 'a campaign of education.'" 
That description of the case does not give the whole position of affairs. Any " campaign of education" such as the American railway companies undertake would be useless, as they know very well, and quite thrown away on the people of New York City and New York State. Experience long ago taught New York people that merchandise (the principal item of traffic is grain) can be carried on the Erie Canal at a lower rate than the railways can carry it. This is not the first time that canal improvements have been undertaken on account of railway improvements having led to rail freights coming down to figures that threaten the canal rates. For many years the railways have reduced their rates from Buffalo (the western terminus of the Erie Canal) to New York to the same as the canal rate while the canal is open during the greater part of the year. Then, as soon as the canal is closed by ice, the railway rates are raised to a more profitable figure. That one well-known fact shows that the canal is the controlling factor in the rate, which is allimportant. Erie Canal traffic is smaller in volume than formerly, because the railways now have a much larger collecting ground;; but the canal freight rate, being the cheapest, governs the rail rates over a wide area, the traffic from which would go to the canal if the railways did not carry at canal rates. The Erie Canal is therefore the governing factor in the situation.

Mr. Acworth states (p. I 54) that "the alleged economic superiority of canals does not in fact exist." In support of this proposition he says that though a first-class barge canal may be cheaper to construct mile for mile, its windings 
add 30 per cent. to its effective length, and one advantage counterbalances the other. Then, he says, a canal boat costs perhaps one-tenth of a railway train, but the railway train does ten times as much work in a year ${ }$; so once again the two are even. A railway, Mr. Acworth continues, earns money all the year round; canals are stopped by want of water in summer, by frost in winter, and lock and bank repairs at frequent intervals. Maintenance charges, he says, are no doubt lower. But canal capital and maintenance charges have to be borne unaided by goods traffic, while a railway spreads them over passenger traffic as well. On the whole, says $\mathrm{Mr}$. Acworth, under these heads a canal shows no saving over a railway. That conclusion hardly appears to be correct; but this summary is inadequate and in some respects misleading. It takes no account of motive power, for instance, the cost of which is an important item. To avoid repetition, however, it will suffice to refer to the previous chapter, in which the chief points influencing the question are dealt with. It is unnecessary to follow Mr. Acworth further in sundry statements and conclusions which rest on "ifs" and on assumptions, not on realities.

Mr. Pratt's book on "British Canals" (published in 1906) contains the arguments of railway advocates who are unfavourable to canals. To any one not conversant with the question, the views and statements given might appear to make a prima facie case against canals in the British Isles; but in this case, as in others, it will hardly lead to sound conclusions to accept the view of one side without hearing the other. 
Mr. Pratt argues that as England is not as flat as Holland, Northern France, and Northern Germany, canals are unsuited to this country. $\mathrm{He}$ mentions several British canals which have been constructed at considerable elevations, at elevations of 400, 500, and 600 feet over sea level, and points out that the canals are uneconomical where such heights have to be got over. That is, perhaps, one of $\mathrm{Mr}$. Pratt's strongest points. But, of course, whether a canal that has to be carried to an altitude of 600 feet will pay. depends on the amount of traffic and other conditions. The canals referred to were built before the days of railways, because there was sufficient traffic, either present or prospective, to make their construction desirable; and results have shown there was justification for their existence. That they are less remunerative now than formerly is due to railways having taken much of their traffic. Possibly some of the canals which traverse elevations of several hundred feet would not have been made if the alternative of railways had existed at the time of their construction. Mr. Pratt's comparison hardly seems to convey quite a correct impression, for he does not appear to remind his readers that every part of the Continent in which canals are to be found is not as flat as the abnormally level region he mentions. And while he draws attention to instances of English canals traversing heights of 400 to 650 feet over sea level, he omits to tell his readers that there are canals on the Continent which are carried to greater heights over sea level than those he refers to in England. The Canal de Bourgogne, on the Plateau de Langres, for instance, is carried to a height of 
I,3 I 7 feet over sea level, and the northern branch of the Canal de l'Est goes to an altitude of 799 feet; the canal from the Seine to the Meuse reaches a height of 91 3 feet; that from the Seine to the Saône a height of 954 feet, ; and the canal connecting the French inland waterway system with the Moselle is carried over a height of I, I 73 feet above sea level. Nor does Mr. Pratt mention that there are flights of locks abroad as well as here; but there are fewer of them. It is true that the country traversed by canals in Great Britain is less level than Northern France, Northern Germany, Holland, and Belgium; ; but the large volume of traffic to be had in England justifies the existence of canals on trade routes with more frequent locks than in various other places.

Then we are told that analogy drawn from the continental canals is misleading and valueless, $)$ that the waterways there communicate with great towns and great ports, and carry enormous through traffic for long distances, and that there is no such traffic to be had here. In short, Mr. Pratt finds that the geographical and economic conditions are not the same in Great Britain and the Continent, and that the inference to be drawn is that canals are unsuitable for this country. Now although some of the circumstances and important particulars are unlike, the essential conditions are in reality analogous. The underlying principles are substantially the same. Our inland waterways as well as those on the Continent communicate with great towns and great seaports; and while the continental waterways carry, as Mr. Pratt says, enormous through traffic long distances, ours (such as the Bridgewater Canal, the Birmingham Canal, 
the Aire and Calder, the Weaver, the Grand Junction Canal, the Trent and Mersey Canal, and others) carry enormous traffic for shorter distances. A large volume of traffic to be carried, one of the essential conditions for inland waterways, exists in Great Britain as well as on the Continent. It would be remarkable if it did not, in a commercial country like Britain. The differences that $\mathrm{Mr}$. Pratt has noted are differences of degree and of detail rather than essentials.

Mr. Pratt states that the canals owned by the Great Western Railway cost the Company $£_{746,034}$; the traffic receipts he gives as $£ 6,58$ I, and the expenditure, $£$ I 2,793. The canal properties represent a dead loss, which the railway, we are told, would be glad to lessen, if it were feasible. If the railway companies, Mr. Pratt continues, had not bought their canals, these waterways must have fallen into disuse, for their owners would not have gone on paying away money for their maintenance, as the railways have done. That way of putting the case will hardly be accepted by many of those who have some knowledge in the matter. In the first place, railways do not maintain their canals of their own free will, as might be supposed from Mr. Pratt's statement : they are obliged to maintain their canals by statutory obligations laid upon them by Parliament. And with regard to the view that other owners would not have gone on paying for the upkeep of canals as the railways have done, the railways obviously have been willing to do so in order to pursue the policy that they have deemed best-the policy of getting as much traffic as possible on to the rails. Otherwise they would 
doubtless have applied to Parliament to be released from their obligations, as they have done in one or two instances. Had the principal railway-owned canals been in the hands of independent companies, it is safe to say they would have been effectively worked and have larger traffics than they have now. There would have been no question of their falling into disuse or being a financial burden to their owners. It is as certain as anything of the kind can be that some of the railwayowned canals which are important links in the chain of through communications would have been more largely used if they had remained independent. Owing to their important locations it is probable that some would have been absorbed and developed byneighbouring independent canal companies-just as, for example, the Grand Junction Canal Company acquired the Grand Union Canal and the Leicestershire and Northamptonshire Union Canal.

Answering the allegation that railways have " strangled" canals, Mr. Pratt refers to the Shropshire Union Canals, and tells of much that has been done to benefit these waterways. He gives this as an example of a railway company saving a canal from extinction, and says, so little has the canal been strangled or even neglected, that several hundred thousand pounds have been spent mainly, in the interest of Shropshire Union Canal traffic. But no one would allege that this canal has been strangled. It is an exception among railway-controlled canals. It is the only canal under railway. influence on which a carrying trade is undertaken by the owners of the canal;; and its carrying trade is worked with some vigour, for, as pointed 
out in another chapter, it does not compete much with the railway company controlling it, but with other railway companies, which accounts for the unusual spectacle of a railway canal being worked in such a way as to encourage traffic.

Mr. Pratt describes how well and economically. particular descriptions of traffic are carried by. railway, and how badly they would be attended to if they went by canal. It is true that on various old, badly-equipped canals the work is not as efficiently performed as could be wished. Mr. Pratt's conclusion from this is that canals are undesirable. He bases his conclusion on the results obtained from antiquated canals. Canal advocates, on the contrary, base their opinions on the work of efficient canals. One might as well estimate what railways are now capable of doing by, the results accomplished in 1850 as form an opinion on the capabilities of canal transport from the old, unimproved, inefficient canals.

Another of Mr. Pratt's propositions is that as England has not the large international traffic of the kind that Antwerp possesses, it would be unwise for this country to follow the example of Belgium in spending large amounts on canals. But does it matter how much of the tonnage conveyed is international or how much is home traffic, provided there is enough of it to justify the existence of an efficient waterway? By many the fact that the bulk of the traffic in this country is home traffic would be regarded as an additional reason for providing canals that can carry at cheaper rates than the present routes.

Then he suggests that the absence of long hauls renders this country unsuitable for canals. It is 
true that a long haul is more economical than a short haul, other things being equal; but the economic difference between long and short hauls is not a thing of sufficient importance to determine a matter of this kind. Was it ever suggested that because as long hauls are not to be had in England as in Germany, Russia, or America, railways were on that account unsuitable for England? The short haul is really an argument in favour of canals for England. In the case of long hauls railways have a greater advantage over canals than in the case of short hauls, because canals cannot compete with them for traffic which needs quick delivery. England is so small comparatively that efficient canals could carry goods between the towns furthest inland and their nearest seaports in little more than twenty-four hours. For most classes of traffic quicker delivery than this is seldom needed. The shortness of haul under these circumstances places efficient canals under little or no disadvantage when competing with railways, even as regards time occupied by transport and delivery; for what the railways collect one day. they deliver the next, and with efficient canals this would be done by travelling all night between inland towns and their nearer seaports.

Thinking it desirable, apparently, to explain why there has been such a large growth of traffic on French and German rivers and canals, Mr. Pratt says it is because the State in those countries has spent large amounts of money on the waterways. But why the French and German Governments have spent so much on waterways he does not explain. It is because after an examination on the subject they have found that inland waterway. 
transport, where the conditions are suitable, is more economical than railway transport. That has been repeatedly stated by official delegates during the discussions on papers read at the International Canal Congresses.

$\mathrm{Mr}$. Pratt argues from the various considerations here referred to, and others, that British traders' requirements cannot be met by canal transport. He admits there are exceptions, but contends that in ninety-nine cases out of a hundred railway conveyance is cheaper and more convenient than canal conveyance. He does not, however, go to the root of the matter. He deals with various minor issues, and does not touch on several matters that are of essential importance, such as the cost of traction, the cost and maintenance of vehicles and vessels, and the cost of maintenance of route, all of which are less costly per ton on canals than on railways under fairly similar conditions.

Neither the railway representatives before the Royal Commission nor Mr. Pratt in his book discusses these essential points on which the canal problem depends. There seems to be nothing in the evidence of the railway representatives to nullify the argument of the previous chapter, that inland waterway transport under suitable conditions is less costly than rail transport. Slight reference is made to matters of the kind, several statements are made, but adequate reasons are not given for the opinions expressed. Mr. Acworth goes somewhat further; but his brief summary of the advantages and disadvantages of each mode of transport is insufficient to draw conclusions from, and he comes to his decision without giving 
his readers sufficient evidence to justify it. It is obvious that the objections urged against canals are for the most part applicable only to old, inefficient ones.

Apart from the main factors, such as the cost and maintenance of line, the cost and maintenance of plant, and the cost of motive power, there are a few other merits and demerits in connection with both railways and canals hardly yet alluded to. Canals are commercially impracticable in many hilly and mountainous districts where railways can work to advantage : canals cannot surmount differences of level as railways can by gradients, but only by means of the more costly locks, lifts, or inclined planes. Localities where canals can be used with economical results are therefore more limited than localities for railways. Railways have the advantage of greater flexibility; they can ascend and descend easy slopes, and they supply more varied wants.

That canals are sometimes closed by ice is of less importance in the British Isles than in some other countries where they are largely used, on account of the shorter and less severe winters here; but even where canals are ice-bound for three months or more in winter, that does not prevent their advantages being appreciated during the other eight or nine months of the year. On canals that are periodically closed by ice for several months the goods required during winter are frequently obtained, as far as is practicable, before frost comes.

The comparative shortness of the journeys in small countries like England, Ireland, and Scotland enables canals in various cases to compete 
with railways without very great disadvantage as regards time required for the transport and delivery of goods. Even with goods for which speed as well as cost is of some importance it is not always the mode of transport that provides the greater speed while actually travelling that gives the earliest delivery. Goods sent by railway are reported to be delayed at times by overcrowded depôts or other causes; and this may. explain why, by travelling twenty-four hours per day, the tortoise sometimes arrives before the hare.

There is also the question of facilities: sometimes they are counted as more important than small differences in rates of freight. Good facilities, such as stores, warehouses, quick, modern methods of loading and discharging goods, through rates, and business-like methods, attract to railways some traffic that otherwise would go to canals. It is of course largely a question of efficiency. and of having enough traffic to justify expenditure on these things. Other advantages of waterway, transport are that goods can, as a rule, be loaded or unloaded almost anywhere along the canals ; and barges can follow or pass each other closely, an average waterway being able to accommodate with safety a larger amount of traffic than an average railway. On the whole, therefore, canals have some other advantages besides providing cheap freights.

The late Mr. E. J. Lloyd pointed out to the Select Committee on Railways, I88I, that the Manchester, Sheffield, and Lincolnshire Railway, Company '(now the Great Central Railway Company) made a slightly larger profit in I 880 from their canals than from their railways. Why this 
Company, unlike most of the other canal-owning railways, made as much as they could out of their canals, instead of adopting the usual railway canal policy, does not appear to have been explained; but the Company is a very poor one, and probably therefore adopted the course that was most profitable.

The case of the Sheffield and South Yorkshire Navigation Company, and their relations with the railway company just referred to, is not uninstructive. Sheffield desired improved inland waterway communication with Goole and Hull, the nearest seaports. There was difficulty in coming to terms with the railway company who owned the canals it was desired to acquire and modernise. It was arranged that until the purchase money was paid by the Sheffield and South Yorkshire Navigation Company the railway company should have the power of nominating a majority of the directors on the board of the navigation company. Less than the required capital was subscribed. The railway company continued to have a certain number of directors on the navigation board. The railway company thus got a considerable sum of money for the canals and yet retained control. Out of the $£_{1}, 150,000$ to be paid to the railway company only $£ 600,000$ was raised; and so it was arranged that the railway company take $£ 540,000$ of ordinary stock out of a total capital of $£_{1}, 600,000$. The railway directors, according to the evidence given to the Royal Commission, control affairs in such a way that improvements have been thwarted. The difficulty of obtaining capital has also prevented improvements being made. The year before the transfer of the canals 
from the railway to the navigation company the earnings were sufficient to pay 3.28 per cent. on the capital. Since then, however, the earnings have been insufficient to pay any dividend on the ordinary stock, and only a portion of the preference dividend.

In another case of attempted waterway resuscitation a railway prevented the project from being successful by lowering rates, to places where the waterway would be a competitor, to such figures that the water route could not compete and have any profit. When waterway competition is put an end to by this means railway freights are generally advanced to figures that were in operation before the competition appeared. It is the same policy that traders and manufacturers adopt to combat competition. The following is an oftenquoted instance : Messrs. Nettlefold, of Birmingham, a large firm of screw manufacturers, more than a quarter of a century ago adopted a policy of this kind in order to do away with the competition of smaller firms, and thus have a monopoly, or more of a monopoly than before, which enabled them to fix prices without regard to competitors. In other trades instances of a similar kind are said to be well known. Railways can afford to adopt measures of this sort for a time on a part of their lines owing to their large resources. It is short-sighted of freightpayers to support railways rather than waterways when this is done. They gain a little by it for a short time, but later on they pay away much more than they gained, because they pay for a long time, perhaps for many years, the higher charge that is made when the weaker competitor 
has succumbed. Yet they do not seem to think of this ultimate result.

It is common knowledge that British railways have been less successful in recent years than formerly. Their large outlays of fresh capital have not been profitable, and dividends have been diminished. The Board of Trade returns show that although the increase in gross receipts in 1907 over 1906 was $4 \frac{1}{4}$ millions, nearly 90 per cent. of this increase went to pay increased working expenses. The increase in net receipts was less than half a million pounds. The total paidup capital increased during 1907 by $7 \frac{3}{4}$ millions. The proportion of net earnings to paid-up capital was almost the same, being 3.47 in 1907 , against 3.45 in 1906 ; and the average dividend on ordinary capital fell slightly, from 3.35 per cent. in 1906 to 3.31 per cent. in 1907 . Obviously there are several causes for the decreased prosperity of the railways. Without further particulars than are now available it cannot be shown from the companies' accounts whether mineral traffic, or certain portions of this traffic, are profitable or unprofitable; but having regard to the large increase of railway capital cost per mile, and to the accompanying decrease in the rate of net profit, it would not be at all astonishing to learn that part of the traffic is carried at a loss.

Although improvements of various kinds have led to economies, net profits for several years past, even during a period of good trade, make it clear that increased working expenses and the increased interest required for new capital outlays have about counterbalanced the benefits resulting from improvements. It remains to be seen whether the 
later economies will permanently benefit the companies to any very appreciable extent. Even in 1907, a year of exceptionally good trade, the proportion of net earnings to capital increased only .02 per cent. over the previous year; a very poor result indeed from the combined advantages of good trade and reduced mileage with an increased tonnage carried. In the circumstances there does not seem any very great prospect of the railways being able to afford reductions in freight to at all the same extent as could be provided by efficient inland waterways.

At the Canal Conference in 1888 the late $\mathrm{Mr}$. Conder said :

"The railway companies seem to have thought, or at all events acted as though they did, that it is better to carry a large quantity of heavy traffic at a low profit than not to carry it at all. If they had taken into account all the elements of the problem, they would have seen they were wrong. Owing to the inadequate accounts published by railways, it is not possible for outsiders to perceive the true state of affairs as to goods traffic, or indeed as to other important questions."

Some of the figures given by Mr. Conder are worth repeating, although they are more than twenty years old, for they throw light on phases of this question; and the lessons to be learned from them are more or less applicable at the present time.

In the report already referred to (to Mr. C. F. Clark, of Wolverhampton) Mr. Conder stated that the time occupied in earning an equal gross revenue by equal weights and mileage of passenger, goods, and mineral traffic is as $1,2.7$, 
and 22 respectively. But while the two former earn on an average more than 92 per cent. profit on an outlay of 100 , the last is not supposed to earn more than io per cent. The net earnings of the different traffics are still more disproportionate rates in reference to capital. And in order to show in another way how much less remunerative goods and mineral traffic really are than is often supposed, $\mathrm{Mr}$. Conder states that in one year passenger locomotives on the Metropolitan Railway each earned $£_{12,176}$, and on the London and North-Western Railway £9,555, while nonpassenger engines on the latter railway earned only $£_{3,504}$. Working the traffic on the railways of the United Kingdom was estimated by Mr. Conder to cost 0.53 of a penny per ton per mile, which is raised by 0.78 of a penny to $\mathrm{I} .3 \mathrm{I}$ of a penny per ton per mile to pay 4 per cent. on capital. An equal volume of traffic on canals could be worked, he calculated, for 0.37 . of a penny per ton per mile, including o.I I of a penny for interest. He also reminds us that it is on evidence that in France, Belgium, England, and Germany, one-third of a penny per ton per mile will pay for transport on canals of adequate section and volume of traffic, and that this figure includes fair interest on capital.

In the same report it is pointed out that coal traffic from the province of Hainault to Paris by the Northern Railway of France pays 0.558 of a penny per ton per mile, which is near M. Krantz's economic minimum. But English railways carry coal to London, Mr. Conder continues, for an average distance of 167 miles for an average freight of 0.476 of a penny per ton per mile, 
although the amount needed for interest on capital on equal volumes of traffic is 33 per cent. more on English than French railways. At the Canal Conference in $1888 \mathrm{Mr}$. Conder gave 0.43 of a penny per ton per mile as the price at which the Great Western Railway conveyed coal from South Wales to London; and he calculated that that price involved loss to the railway.

A writer in the Edinburgh Review of October, I882, making his calculations on a somewhat different basis from those of $\mathrm{Mr}$. Conder, also arrives at the conclusion that British railways carry mineral traffic at a loss to themselves. The closest calculation of the cost price of transport on the railways of the United Kingdom, he says, which has hitherto been found practicable gives for the year $1878,0.2076$ of a penny per mile for every ton of loaded train. This price compares favourably with the corresponding item where it has elsewhere been definitely ascertained. At this price, supposing all the wagons to be full, and the traffic to be conducted on the most favourable conditions, the cost of conveying coal amounts to an average of 0.472 of a penny per ton per mile, allowing for the return of empty wagons. This, however, is for the tabulated working expenses alone. If we take them, he says, as equal to 52 per cent. of revenue, as was the case in 1879 , it will require the price of 0.908 of a penny per ton per mile to pay $4 \frac{1}{4}$ per cent. interest on capital. In other words, the work which is done for a third of a penny by canal will cost nine-tenths of a penny on a railway, the former price covering 5 per cent. interest on capital and a sinking fund, the latter covering only $4 \frac{1}{2}$ per cent. interest and no 
sinking fund. The fact is undeniable, the Edinburgh Reviewer continues, that coals, \&c., of which the value is small in proportion to weight, can be carried on well-appointed canals at a third of the price at which they can be carried on railways.

Mr. Conder and the Edinburgh Reviewer arrive at practically similar conclusions by calculations made from different standpoints. Supposing that they are not approximately correct, and that their calculations and inferences apply only approximately to the present time-for such calculations would now have to be made from somewhat different data-it would still be possible that the railway practice as to mineral traffic is a mistaken one. The chief difference between the data of $\mathrm{Mr}$. Conder's time and the present time is that a much larger tonnage is carried now. This of course reduces considerably the average cost per ton; but it seems rather doubtful if the large quantity carried turns the scale sufficiently to make the traffic profitable when the extra cost of maintenance, due to wear and tear caused by heavy traffic, is taken into account. But suppose that coal traffic as at present conducted were shown, in a way that no one could question, to be profitable to the railways, the cost would necessarily be higher than by an adequate inland waterway, other things being equal, for the reasons given in the previous chapter.

The railway companies' practical discouragement of canals is obvious, but what their representatives stated to the Royal Commission is not sufficient to explain their policy in this matter. The reasons why the railways as a rule have not 
developed and used canals may be somewhat complex; their practice varies slightly, as already shown. The late Mr. E. J. Lloyd, of the Warwick and Birmingham Canal, argued before the Select Committee on Railways, $188 \mathrm{I}$, that the money. spent by railway companies on canals was not to utilise them for the public, but to shut them up if possible, and bring the traffic on to the railways. The principal railways have appreciable amounts of capital invested in canals which they do not work in such a way as to make that capital profitable. The total amount invested by the railways in canals, including loan and debenture capital, up to 1905 , according to the official returns, was $£_{4,8}{ }_{5} \mathrm{I}, 86 \mathrm{I}$. Over $\mathrm{I}, 200$ miles of canals are controlled by the railways. They of course know the remunerativeness of efficient canals, and they, have opportunities of extending trade on their canals. But they evidently prefer to lose money on their canals and divert traffic on to the rails, except in two or three cases already alluded to, where the ordinary railway canal policy (of canal disparagement) is not adopted. There can be practically, no doubt that the loss shown on some of the railway-owned canals might be turned into a profit if the railways so desired, for several of these canals are not badly situated for traffic, yet losses on working are used as an argument by railway representatives for disparaging canals.

It seems anomalous at first sight that the largest branch of the carrying trade in the country discourages the mode of inland transport, which is often the most economical; but a considerable amount of canal transport in England is at present hardly any cheaper than rail transport because of 
the inefficiency of the old and narrow canals, and in a matter of this kind it is usually more economical to keep open one system of transport, with the accompanying staff, premises, and machinery, than to maintain two separate lines of transport, of different kinds, with the double equipment for carrying on business. How much this reason should carry weight would partly depend on the amount of the traffic and the capacity of the principal line, but business men as a rule would prefer when practicable to carry all the available traffic on one system, if that could be done, rather than on two, in order to avoid keeping up a second system and establishment with the attendant expenses.

The railways are able to supply practically all the places of any importance situated on inland waterways. They evidently consider they have least to lose and most to gain by getting all the traffic they can off the canals and on to the rails. They are willing to forgo whatever profit might be made out of their canals in order to carry out a policy of general discouragement towards canal transport, without which, they apparently think, canal traffic would be developed and increased so largely as to take from them more than they lose by the present mode of working their canals. This appears the most probable and reasonable explanation of the railway canal policy. It is quite intelligible, and will appeal to business men. It is not in conflict with the undoubted fact of efficient canal carriage under suitable conditions being more economical than rail carriage.

The railway view, however, if this is it, hardly takes into account quite all the features in the 
case. It could not reasonably have been expected by the railway authorities that British traders and public opinion would not sooner or later become aware of the great advances made as regards inland waterways abroad, and realise the value of efficient canal transport. Nor could it be expected that in these progressive and competitive times traders would remain satisfied without having the advantage of the cheapest kind of transport where practicable. Had these probabilities been foreseen and taken into account, a different policy would in the long run have been better for the railway companies, but it is needless now to discuss in the light of the present position what that policy might have been. In addition to the reason for railway canal policy here suggested, there is of course the motive, common to all carrying companies, that the railways desire as much traffic as they can accommodate, for the larger the tonnage the smaller is the average expenditure per ton, some items of cost not increasing with extra tonnage.

Had the cost of working expenses remained about the same as twenty to thirty years ago, the net result of railway working should have shown an appreciable improvement owing to the natural growth of traffic and the improvements made with regard to fuller wagon-loads and heavier trainloads, together with a reduction of train mileage; these improvements, however, are of a character that are applicable to inland water transport. And, as pointed out in the previous chapter, increasing the load unit can be effected with greater economic advantage on an efficient waterway than on a railway.

The net results of railway working, after the 
economies due to reduced train mileage and other improvements have to a small extent benefited the accounts, do not put the railways in a position to carry heavy traffic as cheaply as adequate waterways under approximately the same conditions. Although the large tonnage of the railways reduces the average expenditure per ton, this is counterbalanced by other elements in the situation, as shown by the net results.

To many, especially to those who have knowledge of such matters, the examples of the Aire and Calder Navigation and the Weaver Navigation in our own country will be sufficient evidence of the economic superiority of efficient inland waterways. Those who desire additional evidence will find it in connection with the waterways of other countries, 


\section{CHAPTER V}

INLAND WATERWAYS IN OTHER COUNTRIES

THE view that inland water carriage is capable of being more economical than railway carriage finds ample support abroad. It is generally recognised on the Continent that where water carriage is practicable it is the more economical of the two methods. It is therefore not surprising that for more than a quarter of a century canal resuscitation has been making progress in Western Europe. Old canals have been developed, new larger canals have been made, rivers have been canalised, and others re-canalised to enable larger craft to navigate them; all for the purpose, which has been achieved, of obtaining lower freights. Much has been done, but, owing to various causes, frequently. owing to lack of available funds, sundry projects that have been considered advisable in several countries have not yet been carried out.

When a solution of a problem is being sought it is frequently useful as well as interesting to see how others have dealt with similar matters. Nations, like people, learn from one another and sometimes adopt each other's ways. Other countries have learned much from England; we now can learn something from our friends abroad. 


\section{INLAND WATERWAYS ABROAD 105}

Canals and canal systems generally depend mainly on trade requirements and topographical considerations. Trade requirements in their important features are tolerably similar in Germany, Holland, Belgium, France, and Great Britain. As cheap carriage as is practicable is everywhere desired;; after the provision of transport systems, that is the chief requirement. Main conditions are very much the same in the countries just mentioned, while the ever-varying details (whose differences are sometimes magnified into arguments against canals) are often simply items in the calculation needed to show whether in the aggregate the necessary elements exist for successful inland waterways.

Railway advocates have drawn attention to the circumstances abroad being unlike those in Great Britain, and have argued that canals are consequently unsuited to this country on that account. In many particulars certainly the circumstances are different. That is to be expected. Nature does not generally make many regions approximately similar. But however details differ-and some differ considerably in degree-the essential conditions, so far as regards inland water transport, are substantially the same in the several countries mentioned. Each country referred to in this connection has rivers that are more or less navigable, and are capable of being made more so. In England, as in France, Belgium, and Germany, the main sources of traffic are largely to be found in particular districts; there are collieries in some districts, certain kinds of manufacturing in other localities, different industries in other districts ; and the great markets and chief destinations for commodities, in England as in 
France, Germany, Belgium, and elsewhere, are the cities, large towns, and seaports situated on waterways. This allows, as a rule, a great part of the traffic to be carried in large quantities to the journey's end, which is more economical, other things being equal, than carrying more numerous consignments to a greater number of different destinations. The differences between Great Britain and the other countries referred to are mainly details, such as the average length of journey, the number of locks per mile, the tonnage of cargoes, \&c.s; but it is the more important features, not details, that show the analogy between British and continental transport requirements. Under the circumstances canal policy and canal improvements abroad are of considerable interest to this country on account of the present position of the canal problem here.

\section{FRANCE}

It would be rather difficult to say in what other country the inland waterway system most corresponds with ours. In some respects the circumstances with regard to the French canals seem more nearly approximate to those in England than elsewhere. In each case the greater part of the traffic is along certain routes, and the total amounts of tonnage carried annually are not very widely apart one from the other. But while the French waterways and average barge journeys are of greater length than those in England, the English canals have more frequent locks. These differences to some extent may be set against each other in their effect on cost. 
The earlier history of canals in France has something in common with that of England. When canal-making on a tolerably extensive scale had begun in England, it soon spread to the Continent ; but less canal construction took place in France than here, probably because the French Revolution, and the unsettlement due to war, prevented it. Then before trade revived, after the long period of depression that followed the Napoleonic wars, the railway had made its appearance, and had caused a great change in ideas about transportation. The older canals were of various gauges. In I 828 a Government inquiry led to a large scheme of development being approved, as improved communications were needed. Three classes of canals were then proposed, but the programme was very far from being carried out when railways appeared, and stopped for the time any canalmaking, for it was at first supposed in France, as in England, that canals could not compete successfully with the new invention. But in France judgment as to canals soon became more correct than in England. There was at no time such a poor opinion of them as existed for many years in this country. Although railways took some traffic from canals, and led to fewer canals being made than if there had been no railways, still inland waterways in France received some attention almost all through the railway period, and the revival of belief in inland water transport came much sooner in France than with us. From 1853 to 1860 , when their value had fallen to a low figure, the Government repurchased the concessions or leases of some of the canals in order to counteract railway monopoly by encouraging canal traffic. As early 
as 1860 commerce made itself heard in France in favour of canal improvement. Several new. canals were made shortly, afterwards at a cost of nearly two and a half millions sterling. From I 870 onwards increased attention was given to the subject, as is shown by papers read and discussions in technical associations, and by the subject being brought before the Legislature. From I 87 I to 1878 over five millions sterling were spent on deepening the Seine, canalising the River Yonne, and improving the Burgundy Canal. This brings us to the end of the period that preceded the revival of canals on a large scale.

The British inland waterway system is now in somewhat the same state of advancement as the French inland waterways were between 1870 and I 880. This makes the report of M. Krantz to the Chamber of Deputies in I874 of some interest now on this side of the English Channel. The report was one of the results of a proposal to spend a large amount on inland waterways. It dealt with the canal statistics of previous years, and showed that heavy goods were carried more cheaply on water than by rail. Some of the chief points shown, on which conclusions were based, were : that canals of average section had cost $£_{I}$ I, 644 per mile, or about two-thirds the cost of an average railway $;$; that where there was a large volume of traffic on canals the cost of interest on capital, the cost of maintenance, and the cost of working the locks was only one-thirty-fourth of a penny per ton per mile; that goods in roo-ton boatloads could be carried at about one-third the lowest railway rates; and that the average difference in cost between rail and canal was $0.32 \mathrm{~d}$. per ton 
per mile in favour of canals; it had been greater, but improvements had somewhat lowered the cost of railway freight. With an annual tonnage per mile of 500,000 tons the charge for maintenance and lock-keeping worked out at only $0.045 \mathrm{~d}$. per mile of goods carried. This is for maintenance and lock-working only, not including interest on capital. This item was given in relation to the point, which had been raised, whether it should be considered that tolls paid in the past had redeemed the previous capital outlay. No sinking fund account had been kept, the question of redeeming capital outlay by means of a sinking fund not having been considered before. The cost of carriage, not including tolls, M. Krantz made out to be $0.234 \mathrm{~d}$. per ton per mile:; but M. Gobert in his essay on "Canal Navigation in Belgium" (I88I), says this figure of $0.234 \mathrm{~d}$. per ton per mile was derived by $M$. Krantz from the canals of Northern France, where the density of traffic is above the average of that of the whole of the country. It is only, M. Krantz showed, when there are large traffics that canals can afford to carry at low rates appreciably under those of railways having large traffics.

Other considerations were taken into account by the French Legislature besides that of which mode of transport was, on its merits, the most economical. It was recognised that canal transport, besides being economical, had a weighty effect on neighbouring railway rates. A large scheme of public works was at the time much desired owing to the lack of employment that followed the war of 1870; and besides the benefits to commerce there were indirect advantages to the 
State from a large scheme being carried out, such as, for instance, the increase in the rateable value of property near the canals. Consequently a large programme of improvement was adopted in 1874 . It was partly based on that of 1828 , little of which had been carried out. It comprised 1,81 7 miles of new waterways needed to give a measure of completeness to the system. About one-third of the cost was undertaken by the State, and twothirds by the communities interested. The standard barge at this time was one to carry 120 tons. After a few years the increase of traffic and the benefits to commerce brought about by what had already been done resulted in further development being desired. In 1878 the Chamber of Deputies consequently appointed a Commission to make further investigations. Apparently they desired some confirmation or corroboration of the soundness of the opinions already acted upon. The Commission reported, among other things: "The differences of freight for long distances between the lowest rate at which a railway can carry, and that which is attainable on a canal, is sometimes equal to half the price of the goods. Economic water carriage will thus equalise the cost of such articles throughout the country.". . . "Thus coal cannot be carried on railways, even for long distances, at a less cost than from $0.54 \mathrm{~d}$. to $0.62 \mathrm{~d}$. per ton per mile, but can be transported by canal at less than half the lowest of those rates-that is to say, for 0.22 d. per ton per mile."

By 1879 , the financial position of France having improved, the "Freycinet programme" for further extending and improving the inland waterways, at an estimated cost of twenty-eight millions sterling, 
was approved. The programme included improving 2,500 miles of rivers and 2,250 miles of canals, constructing 875 miles of new canals, and making locks of uniform sizes. Two classes of waterways were decided on-principal and secondary lines. The principal were to have locks-1 $26 \mathrm{ft}$. by I7 $\mathrm{ft}$., with $6 \frac{1}{2} \mathrm{ft}$. water depth on the sills : the waterways having a bottom width of $32 \frac{1}{2} \mathrm{ft}$., a depth of $6 \frac{1}{2} \mathrm{ft}$., and a sectional area of 297 sq. ft. This size of lock was fixed upon so as to allow the Flemish barges, carrying 300 tons, to trade on the canals. They are $125 \mathrm{ft}$. long by $16 \frac{1}{3} \mathrm{ft}$. beam by $5 \frac{5}{16} \mathrm{ft}$. draught when fully loaded. In the case of the River Seine between Rouen and Paris, the standard depth of $6 \frac{1}{2} \mathrm{ft}$. was increased to meet traffic requirements. The State owns almost all the waterways, and has provided what cannot but be regarded as a comprehensive and fairly complete system, having regard to geographical and commercial considerations. The principal waterways cannot be leased or conceded; the secondary may be, but after the experience of a quarter of a century the Senate and the municipalities are less inclined than formerly to grant monopolies. Since I 880 the waterways have been toll-free, but small charges are made for wharfage, dockage, \&c. Apart from this change there is said to have been no very large reduction in canal freights in the past half-century; for they have always been moderate on account of the thrifty habits of the boatmen, who, with their families, live on board their boats.

The French Government decided several years ago not to spend more money on any additional toll-free waterways. The Baudin programme of 
I 903 enacted that local bodies whose districts will benefit by the work must supply half the cost of new waterways, and must prove their solvencyi; but they (the local authorities) are allowed to recoup themselves by charging authorised dues, and by having a monopoly of a system of mechanical traction, if such is desirable. This programme of 1903 , which the Deputies passed, involved an expenditure of twenty-one million pounds on new waterways and improvements ; but it was reduced by the Senate to between eight and nine millions sterling, not because the improvements were not desired, but for purely financial reasons. The reduced programme includes new canals from Cette to the Rhône, from Marseilles to the Rhône, and a canal in the North of France. These works are about being commenced, and several works of river improvement are also being carried out. The canal connecting Marseilles with the Rhône will, when completed, give that city canal connection with the inland waterway system of France, and provide an alternative route to the P.L.M. Railway, which has long been desired. The Municipalities, the Chambers of Commerce and the Departments, are together contributing half the cost of these new canals, the State providing the other half.

The French excel and take pride in detailed and scientific book-keeping and elaborate accounts ; their Government returns consequently contain many interesting features, and throw light on what might otherwise be doubtful matters.

The Annual Report on .Waterways for 1905 shows that in that year there were 7,2 I 8 kilometres of navigable and canalised rivers, and 4,852 kilo- 
metres of canals, a total of i 2,070 kilometres (about 7,543 miles; a kilometre is approximately fiveeighths of a mile).

The kilometric tonnage on the State waterways was $5,001,443,186$, and on the waterways leased or conceded to others $84,044,615$, a total of $5,085,487,801 ; 42.8$ per cent. of this was on rivers, and 57.2 per cent. on canals.

The principal waterways (those with locks 126 $\mathrm{ft}$. by $17 \mathrm{ft}$. by $6 \frac{1}{2} \mathrm{ft}$., accommodating barges that carry 300 tons) have a total length of 6,002 kilometres. They have a bottom width of $32 \frac{1}{2} \mathrm{ft}$., and a sectional area of 297 square ft. The secondary waterways have a length of 6,068 kilometres. The principal lines had 84 per cent. of the tonnage, and 97 per cent. of the total kilometric tonnage. The secondary lines carried the remaining 16 per cent. of the tonnage, and 3 per cent. of kilometric tonnage.

It is noteworthy that, as the foregoing figures show, much the greater part of the traffic is to be found on less than half the mileage. In one year two-thirds and another four-fifths of the whole tonnage was on the principal waterways. The returns show that improvements of the waterway system have been followed by an increased average length of barge journeys. The Report accompanying the returns points out that the kilometric tonnage on the principal waterways is twenty-eight times greater, and the average length of journeys longer, than on the secondary lines. On the latter the traffic is principally confined to the waterway on which it originates.

The tables for the decennial period from 1896 to 1905 , inclusive, show a kilometric tonnage in- 
crease of 21.3 per cent., or an average annual increase of 2.I per cent. This increase is almost entirely on the principal lines. The percentage of increase on the total system has generally been almost identical with that of the principal lines. Although there are fluctuations from year to year, and occasionally decreases in comparison with the previous years, the total kilometric tonnage has for many years shown a gradual increase. The total figure of the entire waterways for 1905 is higher than ever before. The year 1905 is a typical one; previous and later years' figures show the same general features.

The total tonnage on canals was $18,690,679$, and on canalised and navigable rivers $15,339,788$, making a total of $34,030,467$. Nearly all this amount is hauled by means of horses, steam tugs, and submerged chains, less than half a million tons having been carried by cargo steamers. It is on some of the busier waterways that the cargo steamers are found, and they are chiefly used for long journeys. Electric haulage perhaps can still be best described as being in the experimental stage.

The use, and increased use, of the French inland waterway system is well shown by the kilometric tonnage for each year from I 847 onwards. Apart from fluctuations such as depend on seasons and on the state of trade, and the considerable decreases due to special causes in $1848, \mathbf{I} 858$, and I 870 , there has been a steady progressive increase, which has been greatest since I 880 , when the tolls, which were low, were discontinued, and when part of the last large programme of extension and improvement came into operation. Between 1887 
and 1891 the number of $300-$ ton barges increased from 933 to 2 , or 6 .

The total tonnage using the port of Paris in 1905 was $10,202,828$. 56 per cent. of this amount was inwards to Paris;; 25 per cent. of it was sent outwards from Paris ; I 5 per cent. was through traffic not unloaded in Paris; and 4 per cent. was local traffic from one parr of the city to another. Taking the entire railway and waterway traffic into and out of Paris in 1905 , the above amount carried on waterways formed 46 per cent. and the railway tonnage 54 per cent. of the whole. The total tonnage capacity of the boats that carried the $10,202,828$ tons that passed along the Paris waterways in 1905 was $12,860,235$. The average tonnage capacity was 256 , and the average load 203 tons ; 2 I per cent. of the available capacity was therefore unused. Empty boats are not included in this calculation. The percentage of boat capacity unused on some of the routes is dealt with in these returns, for, as all railway and canal people know, it is an important matter to have as full loads as is practicable. For the twenty-two years up to 1905 the total Paris waterway traffic increased 91.17 per cent., or an annual average increase of 4.14 per cent.

The statistics show that from a commercial point of view it is not worth while to construct a canal in agricultural districts for agricultural traffic ; and it seems very questionable whether it would be an economical proceeding to spend much money on improving or enlarging such a canal unless there was also other traffic or some other object in view. It is considered by some that the canals in agricultural regions of Eastern France would 
be of strategic value in the event of war $;$; be this as it may, the traffic on some of them is so small that from an economic point of view an outlay. such as that incurred on these canals would not be undertaken now.

From I 885 to 1895 some of the French canals doubled their traffics : these increases caused some lowering of freights; but the gradual, though slight, reduction in freight rates on the waterways has been partly due to various improvements. It has been followed by corresponding reductions in railway rates in the districts affected.

Recently the Minister of Public Works made it compulsory on the railways to facilitate physical connection with adjoining canals. This is said to be part of a policy which aims at competing with Germany for certain traffic.

In order to have complete control in carrying out their policy the State maintains the waterways, works the locks, and reserves the sole right, if thought fit, of providing and working the means of traction. The latter provision is necessary, because where electrical or mechanical haulage is used only one method is practicable, and it must be under one control. But the State does not undertake the conveyance of goods.

The policy of inland waterway improvement which has been carried out in France since 1874 was not merely set going and then left to take care of itself. A large amount of money was invested by the State in canals ; the railways competed with them, and the margin of success possible for the large mileage of canals as a whole was at the best somewhat limited. It was, in fact, virtually limited to the advantages to the country. 
from cheap transport and the enhanced value of property adjoining the waterways, with increased tax revenue therefrom. Under the circumstances it was deemed desirable to watch, and, if necessary, protect the waterways from tactics that might be detrimental to them.

Years before the large waterway improvement programmes were adopted it was recognised that powerful railway companies are liable to make unfairly low competitive rates, rates probably unremunerative to themselves, but which they can make because of their large resources. Their small rivals the canal carriers cannot afford to take measures of this sort. When this is allowed it is injurious to waterways and traders. It was seen that a canal policy on a large scale would tend to counteract some of the undesirable features of railway monopoly. Regulations were therefore put into operation to prevent competition on the part of the railways that would be injurious to canal interests. The French railways are owned by the State, and conceded or leased to companies who work them. The operating companies have monopolies, and the effect is much the same as though the railways were altogether independent, except that certain dividends are guaranteed to the shareholders by the State.

What has occurred in England happened also in France. The railway companies, having passenger traffic and very large resources, were willing to make competitive rates, which were probably unremunerative to themselves, for certain traffic that they wished to obtain from inland waterways. What is sport for the railway is almost death for the canal, or would be if the method 
was largely put in operation; for the canal carrier has no second string to his bow in the shape of passenger traffic, and his resources are small. If a fight occurs between the wealthy, powerful railway and the canal company, or canal carrier, the latter can seldom hope to succeed in a prolonged struggle. But the function of the canal is so useful, as a natural automatic regulator of railway freights, that the French Government saw the necessity of protecting waterway transport from its powerful rival in the interests of commerce. This was done by the simple expedient of not allowing the railways to charge less than 20 per cent. over corresponding canal rates unless they. will put into operation all over their systems an equally low scale of rates. This railways are unwilling to do, owing to the large losses it would involve.

\section{Germany.}

In Germany, as elsewhere, canals suffered at first from the coming of the railway. For a number of years previous to 1870 the tonnages carried annually by the canals showed decreases from this cause. The movement in favour of canal revival on a large scale in France had not long been active when a similar movement arose in Germany. After an investigation of the inland transport question the authorities came to the conclusion that inland waterways were desirable-in fact, virtually a necessity, especially for heavy traffic, because of their economy. In 1875 the movement in favour of waterways was taken up with earnestness; and some results were soon 


\section{INLAND WATERWAYS ABROAD}

shown, for a total annual inland waterway tonnage of $33,337,000$ in the seventies, before attention was directed to the subject, rose to $37,954,000$ in 1881 , and from that time onward the traffic has been increasing.

In 1882 the Prussian Government, which has for many years given great attention to inland waterways, passed a resolution in favour of a network of canals constructed on a uniform system. The plan then forecasted is not yet all carried out ; but much has been done. Up to I 893 eighteen millions sterling had been spent on old and new waterways : it is said to have been very. well spent money, the new waterways having been laid out with good strategy from a commercial point of view.

The tonnage carried on the German inland waterways now is, approximately, three times greater than that on the French waterways. It is not quite so much confined to a limited number of routes and districts as in France, because of the existence of seven great navigable rivers, the Rhine, Elbe, Oder, Weser, Danube, Vistula, and Memel, which are named here in the order of their importance as regards the amount of traffic carried on the German portions of these rivers. Four-fifths of the entire inland waterway traffic of Germany is carried on these rivers : half of it is carried on the Rhine. These rivers provide a large part of the entire inland waterway mileage. They are naturally navigable for great parts of their courses ; but canalisation has improved them and extended the navigable mileage. On the natural waterways, the rivers, tolls are only levied in respect of works constructed to facilitate traffic. 
On such fine waterways with these terms freights, naturally, are cheap.

In accordance with national instincts, German methods as to canal and railway traffic are more precise and strict than ours. Their regulations are simple, but rigidly applied. Traders adapt their work to transport regulations, instead of transport people meeting traders' requirements half way, as in this country. There is not the elasticity that results from the English system of company management, but rather the strict discipline of military organisation. Inland waterways in Germany have been dealt with in a comprehensive way. The question was first well studied. The Germans, as every one knows, are scientific, logical, and thorough. They based the commercial and engineering parts of the problem on good foundations, that give satisfactory results. It is agreed that both in theory and practice it is best for the railways and for traders that there should be efficient waterways. The view held by the authorities, after thorough investigation, the policy they encourage, is that heavy traffic should be carried by the waterways, not by the railways, because it can be more economically carried on water, and because the railways are better off without it.

When additions were made to the canal construction programme in 1905 it was arranged that the new projects were to be subject to the States that would benefit agreeing to pay any deficits resulting from receipts not being equal to the cost of maintenance; but the amounts payable were limited to certain figures. In some cases the provincial authorities are to pay interest on 
capital outlay, and certain amounts for sinking funds. In Prussia hitherto the navigable and canalised rivers have been toll-free, and on the canals a low toll is charged, which has usually brought in about one-third of the cost of maintenance; but in order to overcome the longstanding opposition to the great midland canal different arrangements had to be made.

The chief coal-fields had been developed before the older canals were constructed, and neither the canals nor important navigable rivers were very near them. It was largely for the purpose of developing coal-fields that some of the new waterways were undertaken. As some of the great coal regions in Germany are hilly the cost of canal-making was relatively rather high; but it was considered most desirable to make the canals, as otherwise coal had to be conveyed by railway at a necessarily higher rate of freight than would be the case on suitably constructed canals. Among the completed new waterways the Dortmund-Ems Canal, made to connect the great Rhenish coalfields with the port of Emden, perhaps ranks first in importance. It was designed with the object of keeping the traffic it would carry within German territory, and of shipping it at a German port, instead of letting it go to Rotterdam. As, however, Rotterdam was in many respects the more natural port of the two for this traffic, the Dortmund-Ems Canal did not at first attract as much of it as was expected; but eventually arrangements were made which brought more of the coal traffic to the canal. In less than ten years from its opening the traffic grew to $1,700,000$ tons. Previous to the construction of this canal Dort- 
mund was a hundred miles from a German harbour, and not on a river. It was made a port by connecting it by means of this canal with the River Ems. This canal has a depth of $8 \mathrm{ft} .3$ in., but is constructed so that the depth can easily be increased to $10 \mathrm{ft}$. Barges of eight hundred tons are used on this waterway.

The object of most of the new canals is to connect navigable rivers with each other, or with large centres of traffic. The dimensions of the standard canals are : depth, $6 \frac{1}{2} \mathrm{ft}$. ; width at top, $76 \mathrm{ft}$. ; width at bottom, $32 \frac{1}{2} \mathrm{ft}$. ; cross section, $396 \frac{1}{2} \mathrm{ft}$. When the intended new works and improvements are all carried out there will be through communication between all the North German rivers for barges carrying six hundred tons. This size of vessel is due to the existence of the large rivers. The barges, which are now almost all built of steel, are from $206 \mathrm{ft}$. to $210 \mathrm{ft}$. long by $26 \mathrm{ft}$. beam, with $5 \frac{1}{2} \mathrm{ft}$. draught when fully loaded. The design with the spoon-shaped bow, shown by $M$. de Mas to be the most easily hauled, has been very generally adopted. Uniformity merely for the sake of uniformity has not been applied to lock and waterway dimensions. Other considerations have also been taken into account. The dimensions of some of the old locks have been allowed to remain as they were, where they are large enough for the traffic.

Although canal development in Germany has been in the interests of traders and the community generally, it has not suited the views of agriculturalists and certain classes of traders. What they object to is that it brings competition in the shape of agricultural produce, timber, and some 
other things from foreign countries. This, however, is not essentially an objection to canals, but to the extension of means of transport. Similar objections have been made in different countries with regard to railways by bodies of traders whose interests were menaced, or appeared to be so. In matters of this kind, however, persons who suppose their interests will suffer in one direction from altered conditions sometimes benefit sufficiently from increased general prosperity (resulting from the change) to be recompensed for the particular losses incurred. The middle-land canal designed to connect the Rhine with Berlin was approved by the Prussian Parliament in 1905 as far as Hanover, from the Rhine to Hanover. In addition to the opposition alluded to of those who anticipated their markets in Berlin and elsewhere would be spoiled by the cheap entry of foreign produce, an argument put forward by opponents of the measure was that it would diminish the revenue received by the State from the railways (£ I $_{2}, 000,000$ to $£_{15}, 000,000$ per annum), and that consequently new taxes would be necessary. The Government, however, said in effect : " No, the railways benefit from canals; the railways are insufficient for all the traffic, and the revenue from railways would suffer more from the cost of sufficiently increasing the railway capacity than from any loss of traffic to the canal." The opposition, however, was strong, and the measure could only be carried by making concessions. So it was arranged that the canal should be made from the Rhine only as far as Hanover, instead of to Berlin. The estimated cost to Hanover is about $£_{12}, 000,000$. Another concession was that if the 
canal was found to injure the trade of the Silesian coal-miners, steps would be taken to provide them in some way or other with an equivalent for the loss they sustained. And further, the Government agreed to endeavour to get the other parties to the treaty which provides for the Rhine being toll-free to agree to tolls being charged on that river; the object being to increase the transport charges on foreign produce which Prussian agriculturists feared would spoil their markets. The usual provision for the State having a monopoly of traction, if it is mechanical or electrical, was in this case based, not on the usual reason that any other arrangement would be impracticable in working, but on the ground that a charge might be made on imported commodities, so as to prevent them from competing unduly with Prussian produce. The Government were anxious that this long-delayed canal should be proceeded with, and they, therefore, made great concessions. Opposition to the project came from interested parties, and from hardly any other quarter; but they happened to be largely represented in the Legislature. The general body of commercial and public opinion in Germany is undoubtedly favourable to inland waterway transport because of its economy.

There has been delay in and postponement of several of the other canal projects too, owing to financial and semi-political causes. The BerlinStettin Canal has, however, now been commenced. It is hoped soon to put in hand a scheme for making the Rhine navigable for larger vessels from Mannheim to Strassburg, and the Rhine-Hanover Canal is on the point of being begun. But canal 
connection between the Elbe and the Oder, and between the Rhine and the Danube, are still projects of the future.

The method adopted for rendering the River Elbe more navigable is, perhaps, worth mentioning, as there are several rivers in the United Kingdom, in Ireland especially, that might be improved in the same way, where the interests involved do not justify a much more costly system. It is much less costly than the barrage, or movable weir system. Being a large river (it might be said a very large river in comparison with the Thames, Severn, or Shannon), the Elbe would have been costly to canalise by means of weirs and locks, ; and some barge-owners preferred a method which obviated the delays to traffic caused by locks. A Dutch mode of regulation was therefore adopted : arms of groins were constructed from both banks on the bed of the river at certain intervals. These arms generally come to about the normal height of the water. Into the bays formed by these arms sand and silt are deposited, the water there being more at rest than in the mid-river current. The navigable channel is thus narrowed, and its flow of water is therefore quicker; consequently the current scours out the bed of the channel, which is thus automatically kept at a good navigable depth, and dredging is seldom needed. Suitable dimensions are, of course, essential in order to get satisfactory results. The chief objection made in the case of the Elbe to this mode of river treatment seems to be that occasionally in times of drought the water gets lower sooner than it would if there were weirs to pond up the water. The advantages, however, 
outweigh the disadvantages on the whole. This method, of course, is only suitable for rivers, or portions of rivers, without a great fall.

The traffic increase on the new and enlarged German waterways has been large. In 1902 the total traffic had grown to $73,000,000$ tons, $40,800,000$ tons being inwards and $32,200,000$ outwards. This was more than double the quantity carried about a quarter of a century earlier. The greatest increases in traffic are to be found where the waterways and traffics are largest-i.e., on the principal rivers; but the new canals in some places have shown proportionately large increases. It is estimated that over $£ 9,000,000$ has been spent on improving the Rhine for navigation purposes, and some remarkable results have been obtained. Barges carrying two thousand tons can now go up as far as Mannheim. Grain freight by barge from Rotterdam to Mannheim, which in I 878 was eight marks per ton, is now, owing to the river improvements, only two marks per ton. This great reduction is due to the large waterway enabling large cargoes to be carried at little more than the same cost per cargo as when very much smaller barges were used; so that the cost per ton is much less. Yet this great reduction in favour of the river has not injured the railways of the Rhine Valley. Traffic statistics show that increases of tonnage have grown as rapidly on the neighbouring railways as on the waterway.

On the Oder-Spree Canal, which in its former unimproved condition was struggling for existence, the traffic increased greatly after freights had been cheapened by the waterway and locks being enlarged. The traffic before development in $\mathbf{1} 890$ 
was 243,000 tons, and increased in 1902 after enlargement to $1,849,000$ tons. A British consular report tells us that the railway serving the same places as the canal maintained its tonnage while the canal was having this increase.

The traffic statistics of Frankfort before and after the canalisation of the River Main also show that increased waterway traffic was accompanied by increased traffics of about equal volume on the competing railways. The completion of the river canalisation led to a traffic increase of nearly seven hundred thousand tons, which was about equally divided between the waterway and railways. The receipts of the competing railways increased 42 per cent. the first year, and about 58 per cent. the second year after the completion of the work! These instances justify the opinion held as to efficient waterways not injuring railways.

The following figures also illustrate the great development that has taken place on German waterways. The number of steamers employed upon them increased from 830 , representing 33,155 tons (of $2204 \mathrm{lbs}$.) in 1882 , to 1,953 steamers and 104,360 tons in 1897 . The number of other vessels rose from 17,885 , representing $1,625, I_{1} \mathbf{I}$ tons, to $20,6 \mathrm{II}$, with $3,266,087$ tons in the same period. The great increase of traffic indicated by these figures led to further inland waterway improvement. Increase in the size of the vessels used has kept pace with the improved waterways.

It is of interest, by way of comparison with the position of things in England, to note that while railways in Germany have been constantly improving, as in England, the improved waterways 
serving the same places have even exceeded in growth of traffic that of the railways. Export rates are slightly cheaper than internal rates, and the rivers are virtually free to all who wish to place vessels on them. State control results in railway. rates and canal tolls being less governed by the law of supply and demand than is the case in the British Isles : nevertheless, the differences between the two countries resulting from Government regulation does not seem so great as perhaps might be supposed. A number of the ill effects of State control to be found in other countries do not find a place in Germany, owing to the good governmental discipline that exists.

Industry and commerce have increased in Germany largely because raw material was obtainable more cheaply than before the waterways were developed ; traffic consequently increased, and the railways got a share of the traffic, chiefly in manufactured goods. It is not too much to say that many of the manufacturers in Germany owe the existence of their business and their success partly, and in some cases mainly, to cheap inland water carriage. In such cases the railways benefit by the carriage of some of the goods produced, for they carry to many places where there are no waterways, and they get passenger and other traffic which they would not have at all if the cheap water freights had not enabled industries to be carried on.

The apprehension in Great Britain lest railways should suffer injury by canal development does not seem justifiable by reference to German experience. Lord Shuttleworth, the chairman of the Royal Commission on Canals, pointed out during 
the proceedings that as the Prussian State railways earn rather over 9 per cent. on the capital expended on those railways the waterways are not worked to the disadvantage of the railways, as has been suggested. Nor have the immense improvements in the Rhine destroyed the railway. traffic along each bank of the river. A British consular report tells us that in Germany, generally speaking, and in Baden-Baden particularly, railways have benefited by waterway improvements. Corroboration of this has been given at recent International Canal Congresses by Herr Sympher, the chief of the German Inland Waterways Department. He states that waterways and railways have not injured one another in Germany, but rather the contrary. The Prussian Government regard an extensive and growing canal system as not opposed to the interests of the State railways, but as giving assistance to them.

Before the canal revival there was some dissatisfaction with the rates of the German State railways. But technical knowledge applied to the subject enabled both Government authorities and traders to realise that the old primitive canals were inefficient, that railways cannot carry as cheaply as efficient waterways, and that suitable waterways would lead to more economical freights. This knowledge tended to put an end to reasonable dissatisfaction.

Steamers were largely relied on to develop traffic after the opening of improved canals, and they; were successful in accomplishing the purpose. They are given precedence of other traffic. The improved waterways and the amount of traffic are both on a large enough scale to make steam trac- 
tion advantageous. Motor barges, so called, which are really propelled by an excellent type of oil engine, have latterly been increasing in numbers, and seem likely more and more to take the place of steamers. Speed on the canals, but not on the rivers, is limited to two and a half miles per hour, a higher rate of travelling causing silting up of the bed of the canal, and greater wear and tear of the banks.

The large traffic increases that have taken place since waterway improvement began in Germany are not wholly, although largely, due to the cheap freights of enlarged waterways. They are partly due to the fact that Germany in the past thirty-five years has been having a period of very active industrial development. $\mathrm{Up}$ to the unification of the country after the war of 1870 Germany had been mainly an agricultural country. The numerous small kingdoms and principalities acting independently of one another had been detrimental to trade, especially foreign trade. When reorganising unified Germany, Bismarck took steps for making the country more of a manufacturing one than it had been. The result was that Germany. became an industrial country with greater rapidity. than has been the case with European nations generally. In other countries on this side of the Atlantic manufacturing industry as a whole has previously generally been of more gradual growth. In Germany the industrial development in a generation has been phenomenal. That is partly. why waterway and railway traffic increases have been large. If industrial progress had been more normal the traffics would no doubt have been somewhat smaller, and the increases rather less striking, 
but, on the other hand, industrial development could not have been what it has, could not have been at all so great or so rapid, without the cheap transport made possible by efficient inland waterways. The low freights obtainable by the use of large barges on large waterways would lead to increased traffic in most active manufacturing countries.

\section{HOLLAND.}

Every one who has visited Holland must have observed the great number of canals there. It is an exceptional country as regards artificial waterways. It has the greatest mileage of artificial canals in proportion to its area of any country. in the world, but some of the canals were originally, made for drainage purposes rather than for navigation. Large areas that are now firm ground were in former times either marshy or under shallow. water, flooded at times by the great rivers that pass through the country. Land and water in some districts were mixed together by Nature in such a way as to be little or no use to man.

The Netherlands had some experience of dealing with large volumes of water, for the dykes or embankments made in early times to keep high tides and flooded rivers from devastating this low-lying region have been frequently broken during storms in the past eight centuries, and great damage done. Necessity is the mother of invention, and the necessary work of protecting themselves from the sea and from swollen rivers seems to have led the Netherlanders to effect improvements such as benefiting their land by drain- 
age in a way that also eventually helped to provide navigable routes of communication. There was so much waste water in the country, making land useless for agriculture, that it was found one of the best ways of getting rid of it, and of obtaining land for cultivation, was to pen the water into canals, thus draining and improving land otherwise useless, making it fit for cultivation ; and the water, hitherto useless and harmful, soaking the land, was separated, and in the course of time served a useful purpose. In this way some channels originally made for drainage purposes afterwards became navigation canals as well.

In a country with numerous old waterways which were made to accommodate different volumes of water, it is natural to find canals of various dimensions. Those who know Holland will remember that there is considerable variety in the sizes of boats and barges too; but perhaps what impresses strangers most in connection with the waterways of Holland, after their omnipresence, is that they, are used not only for heavy and wholesale traffic as in other countries, but for all kinds of articles. They not only take the place of railways very largely, but they take the place to a considerable extent of streets and roads as well ; for it is wellknown in Holland that it is easier and cheaper to move loads on water than on land. In many towns and villages in Holland household articles, no matter how small, are delivered by canal boat instead of by horse and cart. In the towns and villages boats are to be seen laden with fruit and vegetables from the country or from a market garden, or with butcher's meat or other commodities supplying houses from their cargoes. 
Canals largely taking the place of roads, boats take the place of carts. Boats of many different dimensions are used; there are some carrying only three, four, or five tons for traffic of local character. As in another chapter I have referred to the unprofitableness of narrow boats which carry only twenty or twenty-five tons in comparison with railways and larger boats, it may be well to explain that between them and the small boats here mentioned there is no analogy. These small three or five ton boats in Holland compare with carts and horses or with handcarts in other countries, not with railways. When the boat is hauled by the owner or one of his family, as it often is, the cost is obviously less than carting with a horse.

The saving of expense in business concerns must be considerable where transport is effected as in Holland. In England a man and horse and cart or a man with two horses and a dray will convey a ton, or two to two and a half tons, at the rate of something like twenty or twenty-five miles a day ; in Holland a man with a horse and a boat carrying anything up to a hundred tons, according to the size of the waterway, would travel something like the same distance in a day at little more than the same cost, in some cases probably at no greater cost.

Canals largely occupying the place of roads, it seems natural that they should be toll-free; but there are other reasons why carriage is cheap in Holland. One is that traffic is usually carried by boat direct from seller to buyer, without cartage at either end, the premises of business people being almost invariably on waterways. Then the canals are maintained in an efficient condition, and well 
equipped. Natural growth of traffic and the desire to maintain efficiency and economy in working have led to the expenditure by the Government of over ' $16,000,000$ sterling on canal improvements between 1862 and 1901 . Part of this amount was spent on new canals. Another cause of many. improvements in recent years has been the commercial rivalry between Amsterdam and Rotterdam, each port endeavouring to provide better facilities than the other, so far as circumstances permitted. In pursuance of this policy, and to provide for increasing traffic, Rotterdam is about to build a new port, which will cover about three hundred acres, and be one of the largest artificial harbours in the world.

There are over eighteen hundred miles of navigable canals and about nine hundred miles of navigable rivers in Holland, besides a large mileage of small canals for drainage purposes. Every town and most villages are to be reached by navigable inland waterways, which keep the weekly markets supplied. The network of communication by waterways in Holland is about as complete as the network of railways in England. It serves its purpose and gives satisfaction. Consequently railways were little desired in Holland long after they were established in other countries. They were not needed by the Netherlanders themselves for the internal traffic of their country, but it was eventually recognised, and wisely decided, that railways must be introduced for international traffic and passenger traffic, otherwise Holland would have become much behind the times, and commerce would suffer. It was realised that the railways could not 
expect to get much goods traffic owing to the abundance of canals and the cheapness of transport by them. For this reason it was not to be expected that private enterprise would subscribe the money to make the railways, the probabilities of interest on the outlay were too small, so the State had to undertake the work.

The Government built and equipped the necessary railways and arranged for a private company to provide rolling stock and work the lines. The balance of receipts over expenditure was divided in agreed proportions between the State and the working company. The latter has paid moderate dividends, but the State for many years received amounts only equal to about I per cent. per annum on the capital spent. This arrangement was afterwards somewhat modified. The companies working the railways were placed in the favourable position of not having to earn interest on outlay: for land, permanent way, or buildings, their payment to the Government, who provided these things, being much less than an equivalent for the accommodation received. The railways were thus placed on practically equal terms with the canals, which are State-owned and toll-free, except as regards small lock and bridge dues. The railways can, therefore, charge low freights, and in certain cases can compete with waterway freights. Exertions for a long time were made by the railways to obtain local goods traffic, but with little success ; their goods traffic is largely international, and to a considerable extent obtained by access to places not accessible by waterways.

The waterways have benefited to a much greater extent proportionately, a British consular report 
tells us, by the all-round increase of goods traffic than have the railways. This is partly due to the improved way in which the waterway traffic is carried on. Goods steamers, tugs, and motor boats have greatly increased: time is thus saved, and earnings increased. The boats here referred to as motor boats are not propelled by means of petrol, like motor cars, but by a superior type of oil engine, to which the name " motor" has been given.

Goods can be sent everywhere by canal in Holland. Practically all the local and internal traffic of the country goes by waterways. It is superfluous to say that railways never took large amounts of traffic from the waterways in Holland as they did in other countries. Naturally they have taken a little where circumstances favoured them, but, apart from international traffic, not much.

The circumstances as regards rail and water transport in Holland are, as will have been seen, unlike those in England and other countries. Canals occupy in Holland much the same position occupied by railways in England in relation to the commerce of the country, but there is this important difference : in Holland the lesser used means of transport, the railways, were put virtually on an equality with the canals by relieving them from the necessity of earning a fair rate of interest on capital cost, so that freights chiefly depend, as on the canals, on the cost of transport, while in England, instead of the Legislature putting the lesser used means of transport on a fair level with its powerful rivals, the latter have been allowed to serve their own interests by thwarting 
the conveyance of goods on the lesser used method of transport. In Holland fairness has been aimed at by putting one system of transport on something like equal conditions with the other as far as could be. In Great Britain the railways have been permitted almost to put out of active existence numbers of waterways by severe competitive methods. That the railways have succeeded in their object is shown by Mr. S. Fay's evidence to the Royal Commission that " the railways had little to fear now from canal competition."

From the standpoint of the canal advocate the lesson to be learned from Holland is a satisfactory one. Rail and canal are both freed from the necessity of earning interest on capital cost. Anything like absolute equality as regards conditions in matters of the kind is of course out of the question. Freights depend on the cost of transport. Both canal and rail are well equipped, have modern appliances, and are efficiently handled; but the canals in Holland have the advantage that the railways have in England, viz., they have much the greater part of the goods traffic, and have adjoining their lines a majority of the factories, warehouses, \&c., which are important sources of traffic, which cannot be alienated or exploited by the other system of transport without extra expense, such as cartage, being incurred. This applies to a large part of the traffic, and enables the canal carriers to carry somewhat more cheaply than they otherwise would, as is the case with the railways in England. But the railways in Holland, although they have passenger traffic, which the canals now have not, are not able to compete successfully with the waterways. Exceptional cases no doubt 
there are, but, generally speaking, waterway rates are much lower than corresponding rates by rail in Holland.

\section{BELGIUM.}

The Belgian Government have for a number of years attached much importance to inland waterways as a cheap means of communication. They have had abundant opportunity of knowing the advantages of waterway transport owing to the extent of navigable waterways, especially navigable rivers, they possess. And of course they have been conversant with the cheap inland waterway. transport of Holland and the progress of canals in France. Belgium, as well as Holland and France, owes much to the cheap transport of her waterways. The country is flat and has plenty of water, so is suited for canals. It is well supplied with both canals and navigable and canalised rivers, as well as with railways.

The State maintains the rivers and estuaries, the provincial States the chief canals, and conservancies the minor canals; but the Government exercises control over all the waterways, seeing that the local authorities perform their duties. New waterways and large improvements are obtained by legislation. The local authorities levy tolls, but the revenue from this source must not exceed the average annual maintenance and interest on capital of the waterways in respect of which the tolls are levied. Latterly the plan most in favour has been, not to levy tolls, but to defray costs of maintenance out of taxation. The municipalities construct inland harbours and quays, 
and are empowered to levy duties for their use, to provide interest on the outlay.

The railways and canals are frequently side by side, and are not regarded as hurtful to one another. There is naturally some rivalry, but the regulations do not admit of very much. Traffic usually goes in its most natural channel. As in other countries, traffic is mainly along certain lines; those converging on Brussels, and those connecting the mining and industrial centres with seaports and large towns, have most of the traffic.

The total annual inland waterway tonnage is somewhat larger than the published total inland waterway tonnage of the United Kingdom (which is larger than the actual tonnage, as already explained). The mileage of waterways in Belgium is large for such a small country. In relation to area of country the mileage of artificial canals ranks next to that of Holland, while the mileage of inland waterways, including navigable rivers as well as canals, even exceeds that of Holland. In 1904 the total length was I,349 miles (in a country only about the size of the province of Munster in Ireland). Over 85 per cent. of this mileage is owned by the State.

The locks vary in size on different routes, partly in order to accommodate the prevailing sizes of barges from other countries, and partly owing to local circumstances. The canals to France have locks $\mathrm{I} 27 \mathrm{ft} .7 \mathrm{in}$. long by $\mathrm{I} 6 \mathrm{ft}$. $8 \mathrm{in}$. wide; the canals to Holland and the Rhine have locks $390 \mathrm{ft}$. 5 in. by $52 \mathrm{ft}$. 6 in. to accommodate the large Rhine barges; the locks of the canalised River Meuse are $328 \mathrm{ft} .2$ in. by $39 \mathrm{ft} .9$ in.; and those on the line from Antwerp to Liège 
I $63 \mathrm{ft} .8$ in. by $22 \mathrm{ft} .9$ in. Barges must be I I in. shorter and $7 \frac{1}{2}$ in. narrower than the chambers of the locks, and must not have a greater maximum depth when loaded than $7 \frac{1}{2}$ in. less than the depth of the water on the sills of the locks.

The Belgian Government prefers to provide cheap rates, which are thought to be in the interests of Belgium as a whole, rather than have a profit on the canals. The taxpayers make up any deficiency. It has long been their policy to make all reasonable improvements that will cheapen freights and make the waterways as useful as possible, and to make such low tolls as will benefit the commerce of the country, and bring into Belgium some of the international through traffic that would otherwise pass through Holland, Germany, or France. At present the BrusselsCharleroi Canal is being widened in pursuance of this policy. In I 883 a more vigorous and definite policy, having for its object the capture of international through traffic, was entered upon; it meant, of course, the adoption of very cheap freights. The freights are competitive, based mainly on what figure will attract the traffic. Like competitive rates nearly everywhere, such rates do not sufficiently take cost into account. The low Belgian freights are therefore not a guide as to the actual cost at which goods can be carried, for the State loses slightly on its canals. This may, or may not, be good policy for the country. It seems to be considered good policy in Belgium; and, as it has been continued for a number of years, Belgium as a whole may be supposed to gain more from the handling of through traffic than is lost by, the low rates. 
The method adopted by the Government is to settle the rail freights and fares at figures that it is estimated will yield a small profit, which is to be considered as interest on capital outlay. The average profit, however, is apparently too small to be regarded as even approaching a moderate return on capital. It is hoped that eventually the railway capital outlay may be repaid ; but this is a matter apparently not systematically dealt with, and railway profits in the past do not seem to indicate that there is a fixed intention of doing this. Ordinary canal tolls are fixed in the expectation that they will nearly pay for the cost of maintenance and lock working. Canal freights are of course subject to slight fluctuation owing to competition among bargeowners. But waterway tolls and railway rates have sometimes been too low to meet working expenses, even without taking into account interest on capital. M. Gobert and others mention instances of freights and fares having had to be raised to meet actual working expenses. Sometimes the deficiency is made up out of the revenue from taxes.

Instances given by the British Consul-General at Antwerp show that the average rail freights are considerably in excess of corresponding waterway rates, which sometimes are only about half the railway rates; but as the State fixes the tolls without including anything for interest on cost of construction, these results only show that in Belgium the cost of working, irrespective of interest on capital, is less on waterways than railways. This corroborates experience in other countries. There is no doubt that were interest 
on capital outlay charged to the accounts the result would still be that waterway transport would be shown to be the more economical of the two methods.

The policy mentioned is regarded as fairly satisfactory on the whole: traffics show increases, extensions and improvements are made when thought desirable, and railways benefit from canal improvements in the same way as in Germany. It is not, however, thought desirable in some quarters that traders should be assisted with low. freights in the way they are at the expense of the taxpayers.

The policy of specially cheap rates for attracting international traffic is an important part of Belgian transport policy; but it should be remembered that the low Belgian freights which are sometimes quoted in England and Ireland as examples of what can be done do not properly represent the cost of carrying, because they do not include the charge for interest on capital.

\section{UNITED STATES.}

The progressiveness of the United States makes it of interest to know what the position of the inland water transport question is there. The American canal-making era was later than ours by something like half a century, the United States being at a different stage of development at the time. The Erie Canal, between Lake Erie and the River Hudson, thus connecting the Great Lakes with New York, was the pioneer work of its kind in America. The entire system has a length of 
352 miles. It was made from I 817 to 1825 . Its success led to the construction of other separate canals shortly afterwards, in and near the New England States, the part of the country, then most developed and needing communication; but no large connected system of inland waterways had been made when railways began to appear. The Erie Canal and its connections formed the largest system. At the time referred to America naturally. looked to England for guidance in matters of the kind, and as a result several of the United States canals were brought under the control of railways. Following the English example, canal development was stopped and railways proceeded with, for the country, was needing further communications.

The other canals were not as important as the Erie, and the greater number of them were sooner or later absorbed by railways, or made subservient to them. Some were abandoned, some were converted to other uses. On some of the rivers, chiefly. on the Ohio and the Mississippi, there has been large traffic. On the Ohio River, in 1880 , $11,738,909$ tons were carried, and in 1889 , $16,041,866$ tons; and on the Mississippi, $18,946,522$ tons in 1880 and $29,405,046$ in 1889 . These figures show the large volume of traffic at one time carried by river. In more recent years the railways captured much of it, but the possibility of renewed river traffic keeps the railway rates at moderate figures. Much of the traffic on the great lakes, though inland waterway, traffic, is in its nature more comparable with seagoing traffic than that of ordinary inland waterways. In addition to the Mississippi and the lakes 
there are various other river navigations which have some traffic, which are under the control of the Federal Government. Most of the railwaycontrolled canals have little traffic.

The Miami and Erie Canal, from Lake Erie to the Ohio River at Cincinnati, owing to its very considerable traffic '(largely coal), has latterly. become a most progressive canal. It has 95 locks $90 \mathrm{ft}$. by $15 \mathrm{ft}$. wide. The summit level is $395 \mathrm{ft}$. over Lake Erie and $512 \mathrm{ft}$. over the Ohio River. The total length is 244 miles. The amount of traffic available enabled electric haulage to be undertaken. The barges are towed by an electric locomotive running on rails on the canal bank, the locomotive being supplied with current from overhead wires. Before the electric installation each barge needed two steersmen, two mule drivers, and one cook, also five mules, and the average speed was about two miles per hour. Under the new method each boat requires only, two men, and the locomotive four men in twentyfour hours. The speed has been increased to three miles per hour. "The locomotives weigh about $24 \frac{1}{2}$ tons each, and have two 80 horse-power motors, with a normal speed of 720 revolutions per minute. Each locomotive contains transformers which reduce the voltage to 200 volts for the motors. Starting and running continuously. at three miles per hour, the motors develop 40 horse-power each."

The Erie Canal developed so much traffic that in 1835 , ten years after its opening, its enlargement was decided on. In 1846 further enlargement was demanded and was gradually carried out, the dimensions being increased while the work 
was in progress, until finally, in $\mathbf{1} 862$, the canal was completed, with $70 \mathrm{ft}$. width at surface, $52 \mathrm{ft}$. bottom width, and a depth of $7 \mathrm{ft}$., for barges carrying 240 tons on $6 \mathrm{ft}$. draught. The largest tonnage reached was in 1872 , when $6,673,570$ tons were carried. Tolls were abolished in 1882 , but this did not stop traffic decreases, for railways were spreading and aggressive. In I 895 enlargement to a depth of $9 \mathrm{ft}$. was decided on, but this project was abandoned in 1898 , in view of a larger scheme being considered. When policy is unsettled in this way the number of boats diminishes, for carriers do not incline to build barges that may be unsuitable for new locks.

The canal is the property of New York State. All these improvements were undertaken in order to reduce the cost of freight, partly to enable the port of New York to compete more successfully with other Atlantic ports, and partly to reduce the competing railway rates, for the railway companies in order to get traffic are virtually compelled to carry at the same rate of freight that prevails on the Erie Canal, as long as it is open, otherwise they would lose traffic to the canal ; bargeowners, being able to carry at a lower price, are in the position of being able to determine the rate. As soon as the water route is closed for the winter by ice the railways charge a more remunerative figure. The money spent by New York State on making improvements, which have enabled grain to be carried more economically on the Erie Canal, has, indirectly, been abundantly repaid to them in the opinion of New York people. Railway men sometimes express doubt and disbelief about this; perhaps the best proof that it is so is that one 10 
generation after another, on re-examination of the question, has reaffirmed the wisdom of the policy. of canal improvement.

Owing to developments and improvements of different kinds American railways can now carry goods at increasingly reduced rates. In recent years their grain rates to New York during the season when the canal is closed by ice have again come down to near the level of canal rates;; so the question of Erie Canal enlargement came to the front again some years ago. When this has happened before it has been met by an enlargement of the carrying capacity of the canal, so as to enable the water route to keep in advance of the railroad as regards cheapness of transport. Another route outside the United States has now helped to influence the decision in favour of a thoroughly efficient Erie Canal. Canada has made navigable, on a larger scale than before, the natural waterway route through the great lakes and the St. Lawrence River as the best way of competing with the United States for the carriage of western-grown wheat to the Atlantic. The Canadian water route to the Atlantic, or the Montreal route as it is called in America, has taken a large volume of grain traffic that otherwise would have gone through New York. Ocean-carrying companies trading to and from New York that are losers thereby endeavoured to get the railroad companies to lower their grain rates to New York, in order to attract the traffic going by the Montreal route, but without success. The Montreal route consequently is for the present the cheapest for export grain from a large area.

In 1903 the New York State Legislature sub- 
mitted to the electors, by referendum, the question of again enlarging the canal (the Erie Canal, together with the smaller Champlain, Oswego, and other branch canals which are part of the same system), with the result that it was decided to enlarge the canal so as to make it available for barges carrying a thousand tons. An influential motive on this occasion, as at previous times when bringing the canal up to the needs of increasing requirements had been voted upon, was that the commercial supremacy of the State might be advanced ; thus showing that in a most progressive and highly developed State and city, where railway interest is strong, the effectiveness of efficient inland waterways is appreciated. The policy which had always hitherto been successful was adhered to, and the canal is now being enlarged at an estimated cost of about $£_{30,000,000}$ sterling.

The present enlargement is virtually almost equivalent to the construction of a new canal, for a different location is to be partly used, and the new waterway will have double the depth of the present one. Portions of three large and three small rivers will be canalised, and will have ten movable weirs, having maximum lifts of $15 \mathrm{ft}$. At the last great improvement locks were made I I $0 \mathrm{ft}$. by $18 \mathrm{ft}$. with $6 \mathrm{ft}$. depth : later they were lengthened. Now the locks are to be $340 \mathrm{ft}$. by $45 \mathrm{ft}$., with $12 \mathrm{ft}$. depth of water; instead of 72 locks there are to be 54 , with lifts varying from $6 \mathrm{ft}$. to $40 \frac{1}{2} \mathrm{ft}$. It is estimated that the enlarged canal will carry wheat from Chicago to New York at a cost of $2 \frac{1}{2}$ cents per bushel. The cost of elevator charges at Buffalo ( $\frac{5}{8}$ cent per bushel) and the cost of handling at New York would make 
the total cost from Chicago on board vessel at New York 4.6 cents per bushel, or half the present cost. Although the chief objects in carrying out this great work are to maintain the pre-eminence of New York city as a port, and to reduce the expenditure on freight, it is done irrespective of whether the traffic goes by canal. The canal rate, as already mentioned, governs the railway rate, except when the canal is frozen.

The traffic on the Erie Canal has decreased as railways have developed. This is mainly because the railways cover a much wider area, and have a larger collecting ground. There are some minor influences, but the chief cause is the spread of the railways. In 1905 the total tonnage on the canals of New York State was $3,226,896$; on the Erie Railroad it was $30,791,733$, and on the New York Central Railroad 39,734,512. In that year 91.37 per cent. of the grain and grain produce received in New York arrived by rail ; 8.o I per cent. was received by the Erie Canal, 0.60 per cent. by coast and river, and 0.02 per cent in other ways; yet the cheap water rates governed the rail freights, even though the canal was not used for the traffic whose rates are reduced in this way.

It is scarcely astonishing that in a country like the United States, where the cost of railway construction is relatively very low, where the traffics are large, and where railways are worked with great ability and vigour, the rates of freight should come down to nearly the cost of transport by a canal of only six feet depth. The average cost per ton partly depends, as we have already seen, on the quantity carried; and the tonnage carried in the 
United States is large. Train-load consignments are said to be as frequent there as wagon-load consignments here. It is worth while, because the traffic involved is so large, to make the canal far more efficient, so that remunerative water rates shall be again much below rail rates. This is what New York State is doing, not for the first time. Although the canal traffic pays no tolls, there is no doubt that with 1,000-ton barges, even if reasonable tolls were charged, the waterway freights would be much under rail freights.

Latterly, the inland waterway question has received considerable impetus in the United States because during busy seasons the railways have not been able to carry, within a reasonable time, all the traffic presenting itself. The Federal Government and their advisers did not think railways can permanently or satisfactorily carry, the traffic of the country unless supplemented by. navigable waterways. They have in the past few. years been taking steps towards inland waterway. resuscitation. Several years ago the United States Government sent a Commission to Europe to investigate and report upon the canal question. This Commission reported in favour of inland waterway. transport on account of its economy. Since then Congress has voted increased amounts for waterways. In $1907, \$ 1,750,000$ was voted for further Mississippi improvements, $\$ 500,000$ for the Ohio River, and $\$ 2,000,000$ for further improvement of the navigable channels of the great lakes. Another result of the Commission's report is that Mr. Roosevelt in messages to Congress has advocated inland waterway revival, and the question has been taken up, and is likely, to have good results. 
At the request of commercial organisations, he appointed in 1907 the Mississippi Valley Commission to " prepare and report upon a comprehensive plan for the improvement and control of the river systems of the United States, for the purposes of transport." In a letter to the commission, Mr. Roosevelt said that the railroads were no longer able to move crops and manufactures rapidly enough to secure the prompt transaction of the business of the nation, and there appeared to. be but one remedy, namely, the development of a complementary system by water. In another communication Mr. Roosevelt said that in extent, navigability, distribution, and ease of use the river systems of the United States stand first, yet the rivers of no other civilised country are so poorly developed. The various interests and uses of rivers, he added, are often mutually dependent; and for this reason every river should be treated, he thought, as a single unit.

The United States are reported to have about 25,000 miles of navigable rivers, about 25,000 miles more that might be made navigable, and about 2,500 miles of canals; but a considerable mileage of the latter, owing to railway ownership or influence, is in a primitive state, and inadequate for economical working ; 4,479 miles of canals are reported to have been made, but about 2,000 miles were abandoned.

The importance of inland waterways in America is not, however, to be measured by their mileage or tonnage. The railways have had extraordinary development; ; but the value of canals is recognised as very great, for the railway rates are governed over a large area by the low cost of water carriage, 
in a way not always found on this side of the Atlantic. Evidence of this is to be found in a letter, which has been frequently quoted, written by Mr. Albert Fink, a well-known railway manager, to Senator Windom in 1878 : "You are aware, sir," he says, "that when the rates are reduced on account of the opening of the canal (the Erie Canal), this reduction applies not only from Chicago, but from all interior cities to New York. If that were not the rule the result would be that the roads running from those points to Chicago would carry the freight to Chicago, from which low water or rail rates would take it to New York." The same authority, Mr. Fink, told a Congress committee that the all-rail rate from Chicago to New York is the basis on which rail rates east of the Mississippi and north of the Ohio River are proportioned. Other canals in America besides the Erie have exercised influence on railway rates too. The two great influences controlling railway rates in a considerable portion of the United States are the water. route from Chicago to the Atlantic by the lakes and the Erie Canal;; and the Mississippi, on which vessels would be placed if railway rates were much raised.

The Erie Canal formerly carried far more grain to New York than the railways, because freights were lower by water. Then the railways, in order to get traffic from the canal, reduced their rates; and, having a much more extensive collectingground, they now carry the bulk of the grain traffic to New York $i$; but if they did not reduce rates in the large area already mentioned, so that they may. correspond with those at stations directly, competing with the Erie Canal, then the traffic would 
generally go by rail to the nearest station on the water route, and thence by waterway. The canal is therefore greatly valued, as, if it did not exist, the railway freights would be appreciably higher, as they are in winter when the canal is frozen. Unless waterway freight was cheaper than railway freight, it would be useless in this way. It is to insure having as low rates as possible that New York State is again spending an immense sum on enlarging the Erie Canal. The Mississippi River although it now carries only a small traffic, is probably as great a factor in American export trade as though it was crowded with craft carrying cargo to New Orleans. It may be said that these inland waterway freights are unduly low because no tolls are paid for the use of the waterways, because the freight does not include anything for interest on capital, as is the case with railways. That is sox; but it is counterbalanced, broadly speaking, by the railways having passenger traffic as well as goods, which the canals have not.

Americans look at public works in a largeminded way; and it now seems likely that comprehensive inland waterway schemes will be undertaken in the near future, especially as the American Government is satisfied with indirect results from public works.

\section{ITALY.}

In Northern Italy there is a fairly extensive inland waterway system, which, like part of the Dutch network of waterways, was constructed several centuries ago. Part of it was made in the time of Leonardo di Vinci, who is credited 
with having been the original designer of the canal lock. This system contains 1,733 miles of navigable waterways, mostly rivers, which are connected by canals. To meet modern commercial requirements the system is to be increased to 2, I I 9 miles, as soon as it is considered the national finances will justify the work being carried out. Italy, therefore, like other countries, appreciates the value of water carriage. According to present plans 438 miles of the above total are to be made capable of passing barges of 600 tons; 726 miles are to accommodate barges of 250 tons; 792 miles are to be available for barges of 100 tons, and the remaining 163 miles are to be for barges of less than 100 tons. A Government Commission appointed in 1900 to inquire into the inland waterway question reported in favour of these comprehensive extensions and improvements, although the provinces concerned, Lombardy and Venetia, are well supplied with railways, and have also some steam tramways. The views held by the authorities in Italy about inland waterways are substantially similar to those which prevail in Germany.

Various other countries have features of interest in connection with their inland waterways; but it is the experience of well-developed commercial countries circumstanced more or less as England is as regards commercial traffic that is of most interest to us at present.

It will be noticed that leading features in connection with inland transport policy are somewhat different in the countries referred to, owing to dissimilarity of circumstances. For this reason 
fair comparisons between the cost of transport in one country and another can seldom be usefully made. They are usually misleading, generally owing to varying circumstances and details. France, Belgium, and Germany, all countries with large amounts of commerce, after investigating the problem, each decided that waterways were desirable and necessary as well as railways; and they have spent large amounts on waterway extension and improvement. Holland has also spent a large amount in the same way. The economy of inland water transport is chiefly due to natural causes, which operate in the same way in England as on the Continent. Continental experience in the circumstances is useful to us in a matter if this kind.

Belgium, owing to her geographical position, makes a successful bid for international through traffic, thus getting profits on handling and warehousing. The quick-witted French and the astute New York people were early in recognising, and putting into practice, methods of counteracting the disadvantages of railway monopoly where carried to extremes by providing alternative means of transport, so safeguarded or circumstanced as not to be crushed by powerful rivals. The comprehensive and efficient canal system of Holland, which supplies the traders of that essentially commercial country with practically all they want in the way of internal communication, shows how misjudged is the supposition of those who think that canal carriage is obsolete. In Germany. canals have been constructed to provide cheaper freights than are practicable by railway. And on this point, as to whether rail or canal is 
generally the cheapest, the British Consuls at Amsterdam and Antwerp leave no room for doubt. Our Amsterdam Consul states in an official report that canal freight is cheaper than rail freight in Holland ; and our Consul-General at Antwerp gave the Royal Commission on Canals instances to show that the average canal freights in Belgium are considerably lower than the average rail freights. Canal freights, he pointed out, were frequently: only about half railway freights. Such a large difference cannot be due only to low canal tolls, or the absence of tolls. It is, perhaps, partly due to the low competitive rates put into operation in Belgium ; but as such rates are in operation on the railways as well, it is, no doubt, chiefly due to the inherent cheapness of water carriage.

Not the least interesting of the things we learn from other countries is that efficient inland waterways do not as a rule injure railways, and that, on the contrary, they usually benefit them. 


\section{CHAPTER VI}

WHAT IS NEEDED

IF efficient canals that will benefit commerce are to be provided, certain fundamental changes are virtually inevitable. Proper development of canal traffic naturally does not take place under railway influence. The experience, not only of one country, but of several, shows that the most effective way of guarding against the disadvantages that may result from monopolies is to provide an alternative that prevents monopoly. The most effective alternative to railway monopoly seems to be independent waterways. This is very generally recognised in France and elsewhere. It will be remembered that as long ago as 1872 a joint committee of the two Houses of Parliament declared that it was desirable to free canals from railway control. It is, no doubt, sufficiently obvious that there can be no permanently efficient canals unless they are independent of the railways.

Two of the chief reasons why inland waterway. development has not hitherto taken place in this country (except in a couple of isolated cases) are that the railway interest has stood in the way, and that it was only in rare instances there was any use in canal companies making improvements 
when other neighbouring waterways would not be similarly improved. These two causes indicate two of the primary reforms that are needed. But the removal of railway control alone will not bring to the waterways in their present inefficient state their natural share of traffic. Through communication and through rates by means of independent large canals having modern methods are indispensable between the larger trade centres and seaports in a great commercial country such as England.

It is clear that purchase of railway-owned and railway-controlled canals and amalgamation of canals to form through routes is necessary, in order that there may be no rail ay influence that might be detrimental to canal interests. This is also advisable for another reason: freight-payers, or some among them, would not have confidence in canal administration if there was reason to think that it was influenced by railways. Probably compulsory purchase would be inevitable.

It is not the purpose of these pages to recommend actual projects or definite dimensions. To justify anything of that sort certain statistics would be necessary, some of which are not available. Figures that might be depended upon could only be given after the collection of information and data that are outside the scope of this work. Some of the engineers who gave to the Royal Commission estimates relating to proposed improvements supplied data and calculations; but trade and traffic statistics compiled so as to show the approximate annual tonnages of the chief commodities conveyed between important trade centres and seaports, although needed to make requisite 
calculations, do not appear to have been supplied to the Royal Commission. Whatever the reason, it is to be regretted that such statistics were not obtained. It probably would be worth while for Chambers of Commerce and others interested to have such statistics prepared. It is only from proper data that calculations can be made: otherwise misapprehensions may prevail, and mistakes are liable to be made.

If Parliament approves of canal development, the actual projects to be undertaken, the dimensions of waterways and locks and other particulars would possibly be best recommended by a small working committee, wholly or chiefly composed of well-qualified, experienced canal engineers, who are favourable to canals. Men whose training and opinion have been adverse to canals, men associated with railway interests, would not be likely to do as well in work of this kind as men having thorough belief in waterway transport. Perhaps, however, recommendations as to projects, lock dimensions, \&c., may be made by the Royal Commission.

Though all the data needed for specific recommendations do not appear to be available, general considerations show the need of waterways of enlarged capacity. The conditions exist in various parts of England that would make cheaper freights practicable when waterways are suitably enlarged. There are trade routes already occupied by canals that show how favourable those routes are for the purpose. The British Isles, being near the Atlantic, have a considerable rainfall : there is consequently a good water supply; and although the demands upon it are very extensive, a large amount of 
unused water goes down to the sea. If a comparatively small portion of this immense supply that is running to waste were conserved, it would meet the extra demand of improved canals. Apparently there should be no great difficulty as to water; $\mathrm{Mr}$. Saner does not anticipate any difficulty; but the question is one to be settled by engineers after measuring the available sources of supply. There has been waste in the past by making numbers of small reservoirs instead of dealing broadly with each watershed as a whole. With regard to traffic, England is in some respects almost an ideal country for sources of traffic, industrial centres being numerous and extensive. The internal trade of the country is four or five times larger than the oversea trade. A much smaller percentage of England's internal traffic is carried by inland waterways than in other welldeveloped commercial countries of Europe.

The essential points to be decided with regard to new and enlarged canals are :

The probable average annual tonnage;

The most convenient load unit;

The size of boat to be used;

The speed to be travelled.

When these particulars are known the dimensions of the waterways and the dimensions of the locks can be arrived at.

It is a well-recognised fact that the speed at which a vessel or barge travels partly depends on the size of the waterway it is in. This shows the desirability of having suitable dimensions. The late Mr. E. J. Lloyd, M.Inst.C.E., of the Warwick and Birmingham Canal, was of opinion that with proper dimensions a speed of four miles 
an hour could be as easily attained on canals as two miles an hour, and with no greater motive power.

The proper solution of the question-in other words, the best economic result, the best financial result-depends on the various dimensions employed being properly proportioned to each other. So little attention has been given to canal questions in the British Isles, that on some canals there is economic waste from which no one benefits, and by which shareholders lose, because these matters are not understood, or not attended to. Motive power in such cases often costs considerably more than it ought to, because part of it is used in combating forces that ought not to have to be encountered. Then the angle at which motive power on a canal bank is exerted means economy or otherwise; this comparatively simple detail is also overlooked on some canals.

It is obvious that some waterway cross-sections are better than others, and that the better the cross-section the less motive power is needed. A rough-and-ready test is that the waterway is of sufficient width and depth for a laden boat or barge if the water displaced escapes to the rear of the vessel without being appreciably raised above the normal water level either in front or at the sides of the vessel. The Edinburgh Reviewer already quoted, says : " The speed attained in the open sea shows that two-thirds of the resistance to canal traction is due to the cross-section of the canal." That this resistance " is capable of diminution by increasing the depth and giving vertical side-walls is also apparent."

The best proportion of submerged cross-section 
of loaded boat to cross-section of canal is fairly, well known, although, perhaps, less frequently, found in practice than might be expected, but the best form of the cross-section of the canal is, I believe, yet undecided. It is thought by some to. be rectangular-i.e., with vertical sides ; others are of opinion that a semi-elliptical section is best because it more nearly coincides with that of the boat; but it does not appear to have been demonstrated what is the best form. It is desirable that this should be known, although not perhaps a matter of the highest importance.

Canal dimensions given by Rankine are : bottom width of the waterway twice the width of the class of boat using the canal,; the area, or cross-section, at least six times the immersed midship section of the boat, and the depth of the waterway eighteen inches greater than the draught of boats. Adequate depth is important, as a good deal of the displaced water passes under the vessel. In France it is usual to have eight inches under the keel in the small canals and sixteen inches in the large ones. D'Aubuisson gives approximately the same proportion as Rankine for the cross-section.

The ratio of immersed cross-section of laden barge to waterway cross-section on the Teltow Canal is I to 5. An indefinitely large cross-section beyond the proper proportion is practically useless: but it is important to have a sufficiently, large sectional area in order to economise traction and maintain a proper speed : otherwise there is waste.

On many canals in the British Isles the proportion of barge to waterway is apparently little thought of. What is aimed at generally is to build as large barges as will go into the locks they have 11 
to pass through, in order to carry as large loads as possible. In some cases where the distances to be traversed are not great, and where speed is not a matter of first importance, it is considered that the extra tonnage carried by making barges as large as the locks will admit compensates for reduced speed owing to bad proportions, of crosssections, and for extra cost of motive power due to the same cause. There is good reason for this view. The tendency, however, often is to overrate the advantage gained from the extra tonnage, perhaps because it is more obvious than the extra cost of motive power and the loss due to diminished speed. In some cases the earning capacity of barges would be increased by, somewhat reducing the load and the cross-section of the barge, owing to the greater speed at which the barge would travel, and the reduction in the cost of motive power, resulting from the better cross-section proportion. This is a matter that should be carefully, worked out, not left to opinions or guesswork.

If the necessary statistical information as to traffic tonnages were provided, the dimensions of improved waterways and locks and the speed to be adopted could be calculated when the routes were decided. In most cases old canal routes would be followed, except where slight deviations were advisable, to avoid curves that are too sharp for trains of boats. The existing chief canal routes were well chosen, and using the old canals would cost less than constructing entirely new ones.

The old canals have various defects which naturally suggest some of the improvements needed. Apart from the small dimensions and varied gauges, one of the chief defects of original 
construction is that locks are more numerous than need be ; another is that boat and lock dimensions on barge canals are frequently too short proportionately to width. The relative proportions of vessels on the barge canals are not so good as on the narrow canals. Barges having greater length in proportion to beam than in prevailing types would be better ; they would require less motive power for the same tonnage, or only the same power for a greater tonnage, other things being equal. Adequate and uniform depth of water is essential for economical working on canals. Uniform locks, or rather uniform minimum dimensions for locks, are needed; but to standardise lock dimensions merely for the sake of uniformity where there is no other reason for it would be an expense not as a rule worth incurring.

As different trades have different requirements it is natural that there should be difference of opinion as to what would be the best size of boat for improved canals. The size of boat or barge should depend mainly on what is the most convenient tonnage of load for the bulk of the traffic. Apart from enlarged waterways like the Weaver and the Aire and Calder, there are in this country canals for boats of practically two sizes-the wide or barge canals which accommodate boats carrying from fifty to seventy tons ; and the narrow canals, which admit boats holding twenty-five to thirty tons. Several representatives of canal interests suggested to the Royal Commission that barges carrying a maximum of sixty tons would be large enough for requirements. This view perhaps was based on past and present experience of English canal traffic only. Those who advocate it probably do not see 
their way at present to obtaining larger cargoes. A wider recognition of facts would probably cause them to alter their views. The full value of improved waterways is not realised while old customs prevail. This recommendation must have been made without taking into account probabilities, without sufficiently recognising that enlarged waterways both in England and elsewhere have led to larger traffics: The Aire and Calder and Weaver improvements may be cited as instances in support of this. The experience is general that lower freights increase traffics and make larger barges necessary. There is no doubt the advocates of 6o-ton barges take too narrow and short-sighted a view. Traders are willing to. alter their views, and adapt their arrangements to. changed circumstances, when doing so results in saving of freight. If canals generally were to be made available for only 6o-ton barges, freights would not be appreciably reduced, and canal traffic, if not safeguarded by legislation, would still suffer: from the effects of railways desiring to get all the traffic they can for themselves. The canals would not be able to compete effectively with the railways. There is no doubt a majority of those interested in the question are in favour of a large measure of improvement; they know that without large boats and large waterways freights cannot be much cheapened.

In the absence of adequate traffic statistics, the general circumstances indicate the desirability of enlarged carrying capacity on the inland waterways. The volume of traffic in England, and the advantage, from a carrying trade point of view, of having: that traffic mainly on certain routes, 
compare favourably with the corresponding conditions in France, Belgium, Holland, and Germany, where large barges are used to a considerable extent, because they are most economical for much of the traffic. On main lines, such as those proposed for connecting the Midlands with the Thames, Mersey, Humber, and Severn, anything: less than barges of two hundred to three hundred tons would, if adopted, be likely to be regretted afterwards. England appears to need a maximum tonnage unit for main line canals approximately similar to that for France. She has a larger amount of internal trade, and it largely concentrates on certain routes. The classes of commodities carried on the canals of the two countries are somewhat similar. It will hardly be contended that the larger commerce of England is likely to be best suited by a smaller tonnage unit than is needed in France.

Large barges, barges of two hundred and fifty or three hundred tons, are also desirable for traffic that is conveyed partly by sea. Time and the cost of transhipment are saved, and sometimes the cost of storage and port and harbour charges. Instances of this traffic are : the Forth and Clyde Canal lighters go along the Scotch coast and cross to the North of Ireland,; Thames sailing barges go out along the Kent and Essex coasts;; lighters of three hundred tons go from the Humber to London; coal-lighters go from Boston to the Thames, others from the Tyne to Rotterdam. One tug usually tows three of these. With 300-ton barge canals between seaports and large inland traffic centres, seagoing barge and lighter traffic would increase. The development of a traffic 
so economically carried is a strong reason why the principal inland waterways should be large enough up to various industrial centres for barges of somethingt like two hundred and fifty or three hundred tons.

In addition to the most important lines of canal there are various waterways, some of them barge canals and some narrow canals, having good sources of traffic and fair prospects of traffic development, that it would be advisable to enlarge and improve. They have not as large traffics as the main lines, and would be suited with smaller dimensions. Some of these lines would have more traffic than many of the secondary lines in France, because they have more manufactures. Such canals might with advantage be made suitable for barges of about one hundred or one hundred and twenty tons. Barges of about this size have a distinct advantage, for a number of the existing canals could easily, and at comparatively small cost, be deepened to $6 \mathrm{ft}$. and made to accommodate them, either by dredging or raising the banks, or by a combination of both these methods, and by lengthening the locks without widening them. Some of the canals could be widened, deepened, and side-walled, and have their locks enlarged, all within the present boundaries of the companies' properties, without additional land having to be purchased. Another advantage of barges of about one hundred to one hundred and twenty tons is that they can be hauled by one horse on waterways of proper economic dimensions. Enlargement of the canals would enable the existing 50 and 6o-ton barges to travel somewhat faster and accomplish a greater number of journeys per annum, thus increasing their earning capacity. 
It may possibly be said, Cannot improvement be effected, or sufficient economy attained, by adapting bioats and barges to existing canals instead of adapting canals for larger vessels? If this could be done with advantage, it could be done to some extent gradually, whenever boats needed renewing, and obviously it would be less costly. The objection to this idea is that it would not lead to very much more economical working. It has not been considered sufficiently advantageous to be adopted elsewhere instead of waterway enlargement. But a certain amount of benefit could be derived in some instances by making boats more suitably proportioned to the waterways they use.

Mr. F. Morton in his evidence to the Royal Commission recommended the use of trains of boats or barges instead of larger barges. There is much to be said for that method. It is an economical mode of working, but each has its own advantages, one being best for one sort of traffic, and the other for traffic of another character. The matter is not one to be decided in favour of either method exclusively. The length of the train of barges can be accommodated to the amount of traffic. Trains of present-sized barges would not involve such a large measure of alteration to existing waterways as enlarging them to pass barges of two hundred and fifty or three hundred tons capacity's but in order to lead to efficient working, not only would the locks have to be enlarged so as to pass a train or half a train of boats at one locking, but many of the waterways would have to be more or less widened and deepened, and improved at curves, in order that an 
economical speed might be obtained. The capital outlay for making the canals thoroughly suitable for trains and boats would, no doubt, be a considerable part of the amount needed to make them suitable for large barges. On the other hand, a 300-ton barge would cost less to build than four barges to hold seventy-five tons each. Where there is enough traffic to keep a tug and train of boats fully employed, and the tonnage unit of the train is greater than that of a 300-ton barge, a tug and train is generally the more economical. Where the traffic is large enough and constant enough to keep a steam tug at anything like full work, trains are the most economical, for fewer hands are needed. On the Aire and Calder Company's trains of floating coal-tanks only four men are required on a tonnage that employs twenty-eight men when the same load is in boats or barges. These coal tanks or compartments are $20 \mathrm{ft}$. by $15 \mathrm{ft}$. by $8 \mathrm{ft}$. Thirty of them; carrying forty tons each, are towed in one train.

The experience of other countries having, like England, a varied traffic, is of value in a matter of this kind. In Belgium, France, and Germany, where trains of boats and barges are used more or less, the cheaper first cost of making waterways suitable for trains of comparatively small sized barges did not deter the authorities from providing for large barges "; and that seems the best policy, for the large waterway, though it costs more, will accommodate all kinds of traffic, will permit of greater speed, which increases earning capacity, and will allow for considerable growth of traffic without further capital expenditure.

No one can predict with certainty what descrip- 
tion of craft will be most used on enlarged canals, if they are provided; but it is certain that larger vessels will be used on enlarged waterways. Much depends on the most convenient unit of tonnage. Questions as to the vessels to be employed might be left to those in the carrying trade if it were not desirable to have approximate information as to trade requirements and volumes of traffic in order that waterways may be made of suitable dimensions. Although waterway and lock dimensions should be based on traffic considerations, they might without appreciable disadvantage be adjusted so as to accommodate at one locking multiples of the prevailing sizes of vessels now used.

The shape of the boat or barge is a matter that deserves attention. The Dutch long ago learned from experience that boats without keels are the best for canals, provided they have not to go into tideways, because they are most easily hauled; boats going into rough, exposed waters need keels to help to steady them. Years after this was a matter of settled experience in Holland it was corroborated by a series of experiments made by $\mathrm{M}$. de Mas, one of the chief French canal engineers. His experiments show that different forms of stem and stern of boats made a considerable difference to the tractive power required. The details would take too much space here, as the experiments were numerous. The conclusions were that a boat having bow and stern shaped like the end of the bowl of an ordinary spoon would give the best results, taking into account both resistance to traction and cargo-carrying capacity. With this form of boat bow and stern should be o.r 16 of the total length, the stem cut away at 
the forefoot, and the length of the boat should be 7.7 times the width of beam.

One witness at the Royal Commission objected to canal improvement because traffic would be interrupted while the work was being carried out. But Mr. Bartholomew was able to show that there need be no objection on that account. Widening and deepening the waterway of the Aire and Calder Company, he said, did not cause stoppage of traffic, and did not drive it away. He added there ought to be no interruption to traffic and little delay in converting narrow canals into wide ones. It is clear, therefore, that with the foresight and good management of a capable chief there need be no objection of this sort.

No fixed rule seems applicable to the complex subject of traction, for different requirements can best be provided for in different ways. Trains of boats or barges towed by a steam or motor tug and self-contained barges (those having on board their own motive power) seem to fulfil the largest number of different requirements. The cost of traction per ton of goods carried is lowest with trains of boats or barges, partly because it is spread over a large tonnage, and partly because trains of barges can be worked with two men on the tug and two men on the rear boat. The power required to tow a boat is almost independent of a moderate increase in its length; and this applies but in a lesser degree to trains of boats. Selfcontained barges, whether their motive power is steam or petroleum, suit some descriptions of traffic best, as they can go anywhere without delay, without waiting for steam tug or horse ; and they can go into docks, harbours, and tidal waterways, where horses could not take them. 
On various progressive waterways having fairly large traffics, both at home and abroad, steam has been used for years. In recent years in Holland, motors (oil engines) have been superseding steam. Where the traffic is unsuitable for trains of barges steam or motor power in a selfcontained barge is generally the cheapest method for canals, because one man attends to both the engine and helm; another barge is sometimes towed. But for steam or motor traction it is essential to have waterways of adequate width and depth; for if you have not, either traction costs too much because of the resistance to be overcome due to narrow channels, or the wave produced by the vessel washes the banks and gradually wears them down, generally for about one foot above and one foot below the water's surface, unless the bank consists of dwarf wall, or stove pitching, or other sufficiently endurable material. Another, perhaps more economical, method of protecting the canal banks, and it is a good plan, is to plant at the water level a continuous line of the common rush (Juncus communis). Its roots form a network which keeps the clay from being washed away if the waves are not strong. The height of the rushes is not sufficient to interfere with towing ropes.

There are cases in which horse haulage may still be the most advantageous. Steam frequently does not pay unless there is almost constant work for it. For this reason where work is intermittent internal combustion engines of one sort or another have largely taken its place; they make a steam boiler unnecessary, thus saving space and cost, and preventing the risk of boiler explosion. Animal 
haulage may be the cheapest, where wages and horse-feeding are cheap, and coal relatively dear.

Electric haulage has been tried more or less experimentally on inland waterways in France, Belgium, Germany, and America. For canals it is less advantageous than for tramways, and some other purposes, partly owing to the long distances the electric current has to be carried, which involves large capital outlay to begin with, and large cost of subsequent working. For these reasons electrical traction on canals has not a prospect of being commercially successful at present except where there is a large traffic, and where the mileage is not too great. The costliness of installation, even on a waterway system part of which has a large enough traffic to make electrical traction likely to pay, is against its use, unless such traction would be much more profitable than the alternative mode of haulage. There are very few canal systems where the traffic is large enough over the whole mileage to make electrical traction likely to be profitable. It is more economical to employ one mode of haulage than two, for each has certain incidental expenses, which are peculiar to itself, and necessary ; one set of which expenses would be unnecessary if one mode of haulage only is adhered to for an entire system. At the same time, where one mode of traction is much more economical than another it pays to send all the traffic you can by that method, and traffic which for one reason or another cannot go by it must then be sent by whatever mode of traction is the most suitable. If some form of electric accumulator were invented more powerful and much lighter in weight than any yet produced, it would revolu- 
tionise methods of tractions; but for a quarter of a century no one has succeeded in producing anything having these qualities to a sufficient extent. At present, electrical traction or propulsion on inland waterways can only be considered where the traffic is very large.

On the Brussels-Charleroi Canal and on the Erie Canal electrical traction, tried experimentally, has been abandoned. In both cases the conditions were unsuitable. In the case of the Erie Canal the trial was due to the enterprise of an electrical company, not to canal or barge proprietors undertaking it.

On the Canal d'Aire et de la Deule at Douai in the North of France ten miles of canal have for several years been operated by electrical traction $_{7}$; and on the Teltow Canal, near Berlin, a length of twenty-five miles has been equipped for electrical working in a very thorough way. This canal is $65 \mathrm{ft}$. wide at the surface, and has a depth of $8 \mathrm{ft} . I_{2} \frac{1}{2}$ in. The total cost of the electrical installation on the Teltow Canal was $£_{1} 50,000$, and it is calculated that it resulted in a saving in the cost of traction when the traffic exceeded two million tons per annum. In France and Belgium it is considered that electrical traction would not be profitable unless there were a larger traffic on this mileage. The method of working is the same on both the d'Aire and Teltow Canals. The tractors, or locomotives, run on a light railway. track laid on the towpath. This is found to be the most economical method for canals by Messrs. Siemens and Halske, who designed the system and put up the plant on the Teltow Canal. The locomotives weigh 8 tons, have two 8 horse-power 
motors, have a continuous current of from $55^{\circ}$ to 650 volts, and cost $£ 700$ each. One hauls two barges, each carrying 600 tons, at a speed of $2 \frac{1}{2}$ miles per hour, the maximum speed allowed. The cost, with power at Id. per Board of Trade unit, is .0056d. per ton-mile for current.

In cases where there is a very large traffic per mile electrical haulage may be the most advantageous if conditions are favourable, but steam and motors, especially the latter, are at present the best for canal purposes generally. In the future probably electrical traction may be commercially practicable to a greater extent than now.

Inland waterways should be as free as possible from everything that delays vessels. Locks cause more delay than anything else except badly proportioned dimensions. Canals cannot be considered efficient where there are more numerous locks than need be. The number of locks should be reduced to a minimum. Doing this, and increasing their rise, has the advantage of increasing the size of levels and lessening the fluctuation of water level due to locking. For trains of boats especially, owing to the longer time they take to get through a lock than single barges, it is important to have locks as efficient as can be. Time can be saved by longitudinal sluiceways with numerous side outlets to the lock chamber. Intermediate gates and side ponds will save water where desirable. In short, by, utilising where they, will be of service the best known methods increased efficiency is to be had.

The greatest improvement of all for raising and lowering vessels between two different levels of a canal is the substitution of the hydraulic lift for 
the lock, where the difference of level is so great that a number of locks are required. Lifts make canals practicable where not so before; they save time and water; but where the difference of level to be overcome is a comparatively small one, two or three locks would generally be more economical. Lifts are generally better than inclined planes.

The Anderton lift, opened in 1875 to connect the River Weaver Navigation with the Trent and Mersey Canal, consists of two caissons supported on and raised by hydraulic rams. Gravity is made use of as motive power, syphons regulating the water in the ascending caisson so that the additional weight of the descending caisson helps to raise the former. In Belgium and the North of France hydraulic lifts are also in use; one at La Louvière surmounts a rise of $217 \mathrm{ft}$.

Several of the rivers whose navigable qualities need improving could best be dealt with by means of the barrage or movable weir, the plan of which was devised a number of years ago by. French engineers with the twofold purpose of making rivers navigable or increasingly navigable, and preventing adjoining property from being flooded. These weirs have been adopted in Germany, Belgium, Egypt, the United States, and to a partial extent on the Shannon in Ireland. The new weir at Richmond on the Thames is an adaptation of the same principle. Experience shows that they serve exceedingly well the purposes for which they. are intended. Until these weirs were put into operation it used sometimes to be said that the interests of navigation and of drainage did not harmonise, and could not be made to agree, 
because navigation required a good depth of water, and those interested in drainage and flooding desired the water to be kept at a lower level. That was a popular view rather than a scientific one. When a proper study of the question was made by men qualified to deal with it, it proved to be easy of solution. The problem to be solved was how to keep up a sufficient depth of water for laden barges, and at the same time to keep floods within the banks of the rivers, and get rid of them quickly. Weirs were accordingly devised consisting of a framework entirely filled with sliding shutters or gates across a whole river, constructed so that they can be partly or wholly, raised, and flood water thus let pass down as fast as it comes. These weirs vary much in design, but are alike in principle. Large gates in large weirs are worked by means of travelling winches. Some forms of barrage, such as the so-called needle weirs, are worked by hand. When canalising rivers by means of movable weirs with locks beside them, greater depth of water is thus obtained; but it is sometimes supplemented by. dredging or by raising the banks, or by both these methods, as was found desirable in the case of the River Seine.

Successful working of the movable weir depends on the proper carrying out of preparations for approaching floods. The weir-keepers are connected by telegraph or telephone, and the depths of rainfall and of water in the upper parts of the river are communicated to the weir-keepers lower down. Their instructions tell them how much to raise their weirs for each inch of rainfall, or rise in the river higher up; so that before a 
flood gets down to the weir-keepers, they have sufficiently raised, opened, or removed the gates, and it passes on practically unobstructed. Occasionally floods are too great to allow barges to travel, but delays due to floods are reduced to a minimum by this excellent system. Its partial adoption on the Shannon has brought about marked improvements.

Put briefly, the essential difference between the barrages and the old style of solid fixed weir is this : the new style of weir can be opened, or practically removed, all across a river, when need be, while the old fixed weirs, having usually only a few sluice-gates, delay floods getting away and thus cause them to overflow the river's banks.

Were canal improvement undertaken, legislation would be needed, Mr. Bartholomew told the Royal Commission, with regard to amalgamation, new works, empowering canal companies to advance capital to each other, acquisition of land, enlarging bridges, additional water supply, the application of the principle of the Light Railways Act (I896) to canals, and requiring railways to exchange and distribute canal traffic fairly. To this list might be added, requiring railways to pay half the cost of facilities for exchanging traffic, and exempting railways and canals from taxation in respect of other railways, tramways, and canals that compete with them.

In the interests of through traffic, and of traffic generally, it is desirable that small canals, sometimes only a few miles in length, should not be in a position to charge higher tolls than are charged on neighbouring canals : this they frequently do when they adhere to their right to charge maximum 
tolls. For this reason amalgamation of such small canals with others should be made compulsory, even if not necessary in connection with projects of canal enlargement.

The commercial organisation of canals and canal transport needs to be more like that of the railways. Through routes should be under control as uniform as that of the different lines of railway. Through tolls and rates of freight to all parts of connected waterways should be made, as required. Business-like equipment and facilities suited to the amount and character of the traffic are necessary, equipment such as warehouses or stores for goods, cranes, and other facilities for loading and unloading cargoes ; in short, the usual facilities for goods traffic, commercial and otherwise, provided by railways are needed by canals as well.

Next to enlarging the canals, so as to make them efficient and economical, there are few reforms in connection with railways and canals in this country more needed than establishing an adequate system of ton-mileage accounts. It cannot be known with sufficient accuracy what the cost of carrying different commodities really is until this is done. The cost of maintenance of line, of rolling stock, of motive power, and other heads of expenditure on railways, and the cost of motive power and of maintenance of line and of barges on canals for each principal class of commodity carried is essential information, so that it may be known what certain work costs under each of different headings, what should be charged for it, and what profit it gives.

During a discussion on American railway. accounts at a meeting of the Royal Economic 
Society (London) in December, I908, Mr. W. M. Acworth said that every European country having modern standards of civilisation had adopted tonmileage statistics for its railways except England, Belgium, and Portugal. On the same occasion a most effective illustration of the value of these really indispensable statistics was given by $\mathrm{Mr}$. G. Paish, the statistician. He stated that on the (American) Great Northern Railway the percentage of working expenses to receipts was reduced from 60 per cent. to 48 per cent. entirely as the result of investigations as to why ton-mileage costs in relation to some commodities at some places were higher than the ton-mileage costs of similar commodities at other parts of the line. These differences, Mr. Paish stated, could never have been discovered if full detailed ton-mileage statistics as to each commodity carried had not been produced. Having ascertained why more was spent on certain services in some divisions of the railway than others, it only remained to bring down the expenses where they were high to the level of the places where the costs were low by putting in operation, where necessary, the more economic methods. Hence the reduction of I 2 per cent. in the proportion of working expenses to receipts. So incredible did this large reduction at first appear, Mr. Paish stated, that he and others were sceptical about it; so he went to America and was allowed to make investigations, with the result that he found there was no need for scepticism, and that the facts were as had been represented.

On American railways, Mr. Paish stated at the same meeting, ton-mileage statistics were formerly 
objected to by the companies on the grounds that it would cost a great deal to keep the necessary accounts, and that the results would not justify the cost. The American railways, however, soon found that the cost was very little, and the usefulness of ton-mileage accounts very great. It is said that the railways here make similar objections. If this is so, it shows that the railway, authorities in this country do not yet realise the value and importance of these statistics.

It would probably be true to say that had tonmileage accounts as full and detailed as those now kept in the United States been kept and used in the United Kingdom during the past quarter-century, British railways would be in a better position than they are now. Useful and accurate statistics are more than ever needed in order to show the weak places that are capable of amendment, that are not likely to be otherwise discovered. It is sometimes said that the very varied circumstances of English traffic would make ton-mileage figures of little use; but in America they have even greater variety of conditions and find the tonmileage method applicable and valuable. The American railways, which every one will admit are managed with great ability, base all their calculations, we are told, on ton-mileage figures. Where this is done freight charges can be based on these figures, and traffic shown to be unprofitable can be either got rid of or charged a price equivalent to the service rendered, and data the railways would not otherwise possess would be available for developing the more profitable traffic. European countries that adopt modern methods, as well as the United States, have, it appears, 
adopted the system, as the best method in existence for producing accurate foundations for calculations and decisions that otherwise have to depend more or less on opinions and guesswork. Tonmileage statistics would save the time of managers because they show data needed for safe conclusions.

Sir George Gibb, when general manager of the North Eastern Railway, after studying American methods, adopted improved railway accounts, including, it is said, ton-mileage accounts to some extent ; but outside the railway company's offices the results do not appear to "be known. A few of the other railway companies in this country are reported to use ton-mile figures to a small extent for their own information : but unless complete statistics, such as already mentioned, are available their usefulness is limited.

The following abstract from a paper on this subject by Mr. Apjohn states the case so well that I cannot do better than give it here :

"In a large and complicated business, statistics are needed to show what is being done, and at what cost and at what profit or at what loss, in many different profit-earning and other departments, and to enable comparisons to be made between facts derived from similar sources and systems, and for throwing light on various more or less obscure problems.

"How railways and canals can be most ieconomically and efficiently worked, and what prices ought to be charged to the public cannot be well arrived at without statistics showing the cost of various kinds of services. This cannot be ascertained without recording the number of 
passsengers or tons carried, and the distances they were carried. In other words, the total unit mileages are necessary: with these data and a proper classification of expenses, and the division between passengers and goods in proper proportion of such expenses as are common to both, the average cost of carrying a passenger or a ton of goods a mile can be known. The statistics are known as ton-mileage figures. The train mile is not so good a unit; it is a more variable one. The passenger and the ton being units of charge to the public, it is desirable to have the cost of performing the service on similar units.

"The process of arriving at the figures cannot be one that is absolutely exact ; it is sufficiently. so for practical purposes; but the problems for solution do not call for absolute precision. Without ton-mileage statistics comparisons approaching exactness between English and continental railways and canals cannot be made. English railway accounts do not go beyond giving receipts and expenses per train mile. This is not much guide to economical arrangements. Good arrangements consist in keeping down the train or boatmileage and keeping up the train-loads. A train mile is a very variable unit, and, therefore, likely. to mislead. Many Board of Trade reports regret that it is impossible to show what is the receipt per ton per mile (on English railways) which would indicate decisively whether more business is being done at a cheaper rate.

"The objections to ton-mileage statistics on the part of railway people seem to be that they are difficult to arrive at with accuracy, and that they. are of little use. In America the information is 
arrived at without much difficulty, and is found to be of the greatest service in ascertaining where economy is needed and in fixing reasonable rates and fares. The process for preparing the statistics is now so perfected that there is little if any difficulty-which would be easily overcome. In America the figures are given for different parts of a line, as well as for each line as a whole.

"As in the case of many, if not most, rates competition is a governing factor, it is obviously desirable to know the cost of the service, otherwise a ruinous competition may be carried on. The present unscientific plan probably involves loss to proprietors and in some cases higher charges to the freight-payer.

"British companies would save much time and trouble if instead of working out a process of arriving at ton-mileage for themselves they would adopt the ton-mileage methods used by American railway companies. It would remove probably. much of the dissatisfaction with freight rates if those rates were founded on intelligible principles instead of an estimate of what the traffic will bear. While other things require to be taken into account, the charge for freight must obviously depend chiefly on the cost of the service."

This is a clear and convincing statement in favour of ton-mileage accounts.

In the event of canal companies being in control of improved canals, if this form of control is adopted, it will be a matter of some importance to freight-payers whether the companies themselves are carriers, as are the railways, or whether the carrying trade is left to private firms and companies of boat and barge owners. There does 
not appear to be any sufficiently good reason why the canal companies should not undertake the conveyance of goods, and there are strong reasons why they should do so. The great advantage of canal companies themselves being carriers is that when a responsible company in a large enough way of business to do things well is doing the work a much larger traffic is attracted to a canal. A canal company almost always provides better business organisation and a larger number of regular services than do firms of barge-owners. It does better for traders than when the carrying trade is left to others. It is true there are some firms and companies, such as Messrs. Fellows, Morton, and Clayton, Limited, and some other smaller concerns, who do their work in a businesslike way and provide facilities of various kinds; but they are the exceptions that prove the rule. If a canal company carries goods, suitable equipment and facilities are generally provided because it pays to do this; if, on the contrary, a canal company does not carry goods, it is not generally considered sufficiently to the interest of either the canal company or the boat-owners to provide good terminal facilities such as are necessary for a large general trade. The majority of canal carriers who are not canal-owning companies are in a comparatively small way of business, many of them doing a somewhat irregular trade, and it would seldom pay them to provide the things needed to attract a much larger traffic. It could not be expected of them. Their class of business is more or less analogous to that done by "tramp" steamers.

Experience shows that if an adequate traffic is to be carried on a canal it must generally be 
undertaken by the company owning the waterway. After the Leeds and Liverpool Canal Company a number of years ago resumed possession of their canal, which had been leased for years to a railway, they found they could not get sufficient traffic unless they became carriers themselves, and accordingly they became carriers; and the Grand Canal Company (Ireland) certainly would not have at all as much traffic as it has long had if the Company themselves were not carriers. The only railway-controlled canal that undertakes a carrying trade (the Shropshire Union Canal, controlled by the London and NorthWestern Railway) appears to have become a carrìer in order to increase traffic. It will be remembered that this canal, instead of being mainly a rival of the railway that controls it, competes more with other railways. It is apparently worked as though the owners wished to get traffic that otherwise would be carried by other railways than the North Western, and as though they wished to make something out of this canal system; what they have done to attain these ends is to carry goods themselves. On their canals which, owing to location, compete with their own line of railway, the North-Western adopt the usual railway canal policy, not carrying goods.

Improved inland waterways would stimulate and encourage traffic; and if canal interests owing to this and other causes were well supported, perhaps it might serve the purpose not to make it obligatory for canal companies to be carriers ; but in that event it would be well to provide that if sufficient carriers and sufficient boats for reasonable trade requirements did not appear, then the 
canal company should either undertake the carrying trade, or arrange for it to be done by others on an adequate scale.

A Canal Clearing House is another of the administrative reforms considered necessary in the interests of inland waterways. It was authorised by the Railway and Canal Traffic Act, I 888 , but has not been established. The reasons for desiring a Canal Clearing House separate from the Railway Clearing House, to which a number of the more active canals belong, remain the same as when it was provided for. A convenient time for it to commence work would be when improved canals are opened. Joining a Canal Clearing House would, of course, not prevent canal companies desiring it from being also members of the Railway Clearing House.

A matter of considerable importance, seldom mentioned in connection with the canal question, was brought under the notice of the Royal Commission by Mr. Bartholomew. This is the control and ownership of harbours, ports, docks, and tidal rivers by railway companies, who naturally work these harbours, \&c., in their own interest. This is sometimes to the detriment of canals; the suggestion made is that they should not be allowed to have exclusive control of harbours, for it is frequently against the canal interest and against that of freight-payers. Inland waterway interests feel that they do not get fair play. In some cases railways have acquired lines of steamships as well as harbours, thus getting practically a monopoly, which is against the interests of inland waterways. One interest controls harbours, \&c., to the disadvantage of another. Like the 
question of railway-owned canals, it is a matter that comes up for decision with other parts of the canal problem. Presumably only the harbours, docks, \&c., with which navigable inland waterways have connection are intended to be affected by the proposal. It is essential to inland waterway interests that they should have good facilities in this matter. In some cases cheap rates depend on barges going direct alongside sea-going vessels, thus saving the expense of cartage and storage. There is a considerable amount of export and import traffic conveyed by inland waterways that is sent in this way because charges at the ports are less than when the traffic goes by rail.

As tideways are national highways it seems reasonable that the State should improve them, for liability goes with ownership. The State has given large powers to railways in the public interest : inland waterways in the public interest need ample facilities for using harbours, docks, \&c., otherwise the waterway traffic will be liable to suffer delay and inconvenience, for railways will naturally give precedence to their own traffic. Fair play for canals might be provided by legislation to the effect that certain harbours, docks, \&c., should be controlled by boards of business men so composed that no single interest or industry would have a preponderating proportion of members. The Board of Trade should be represented. The railways would receive fair play because they. would be large customers of the Harbour Board.

In the event of private enterprise being decided upon as the best for an improved inland waterway system, the area, or unit, of control must of necessity be larger than at present. Two pro- 
positions have been made : one is that each main through route (and its branches) should be under separate control; the other is that each of the principal watersheds of the country should form an area of control. The former plan is recommended for its commercial convenience, the latter as it would be more suitable from an engineering point of view. There is a certain degree of fitness and economy in making divisions of this sort coincide with natural areas, when that can be conveniently done, but if areas of control in this case were to be made to coincide with the boundaries of watersheds some through routes would be cut in two. Trade routes overstep geographical divisions very largely; and it is generally more convenient for main traffic routes to be under one control than under two different authorities, even though uniformity in certain essentials had been provided for by legislation. Where necessary a through route can take supplies of water from two or more different watersheds, as is done at present by several canals. As the reason for the existence of an inland waterway system is that it may serve commercial purposes, and as its success depends on suiting trade requirements, the area of control clearly ought to be what will best suit commercial convenience. Through routes as a rule should, therefore, be under one control, as is usually the case with railways. 


\section{CHAPTER VII}

STATE CONTROL OR PRIVATE ENTERPRISE

CANAL policy in its main, broad features must usually be settled on the same lines as railway policy. As recent discussion on State ownership of means of communication has had reference chiefly to railways, the pros and cons given here are largely those relating to railways; but the arguments, or many of them, also illustrate the case with regard to canals, and apply as well, generally, to canals as railways.

The relationship between the State and the railways has occupied a certain amount of attention in recent years. Various public speakers and writers have pronounced in favour of changes, or change of some kind; but adequate reasons scarcely appear to have been given for such changes as have been suggested. The suggestion, however, is one to be considered.

The view long held, largely the outcome of generations of practical experience with regard to such matters, was that the province of the State is to undertake works of general utility that would not be carried out by private enterprise or by local authorities. Latterly there has been a tendency in favour of the State undertaking 
somewhàt greater responsibilities. Government already engages in enterprises of a business character. It purchased the telegraphs in 1870 , for instance, and has for many years run a telephone system. Experience, so far, shows that changes of the character referred to have not proved particularly advantageous. The State supervision has been extended to various matters, and suggestions are sometimes made that it should be further extended.

Unfortunately, difficult problems are sometimes not sufficiently examined before legislation with regard to them takes place. Public opinion is not always a safe guide, for it is sometimes insufficiently informed on subjects that present themselves for decision. The majority of people have no opportunity of getting adequate information on most public questions. For instance, when M. de Lesseps came to England to endeavour to get money for the construction of the Suez Canal, the Government, leading newspapers, and public opinion opposed his project. It is true that Frenchmen hoped that by making the Suez Canal they would obtain some of England's shipping trade; but had Englishmen thought well of the project from a business point of view that would not have prevented them from subscribing towards it. Years afterwards leading newspapers and public opinion appear to have seen that a mistake had been made in the past, for the purchase of Suez Canal shares that was made by the Government was very generally approved.

Various reasons have been alleged by men in public positions why some change is desired with regard to railway control. It is said by some that 
the nation generally would benefit by State control. It is said by others that divided control causes conflicting interests, and therefore national control would be better. By " divided control " is meant that the railways and canals are subject to the will of Parliament as well as controlled by the directors and officials. It is also said that State control would give greater uniformity in some respects, and that this would be an advantage. These points are general, if not vague, in character, and they are not supported by adequate reasons. Then it is said that the evils of railway monopoly would be avoided by State ownership. Perhaps some disadvantages might be remedied; but there are others not easy to remedy, which have not been remedied in countries where there is State control; and there are other evils of different kinds which almost inevitably come into existence under Government control. State ownership, moreover, would involve a larger monopoly than before, but one of a different kind. Another complaint is that there has been wasteful expenditure, such as the unnecessary duplication of services, owing to rivalry between different companies. This is a matter that concerns the proprietors more than others : it is partly a result of competition, which it has been the settled policy of Parliament to encourage for more than a quarter of a century. Another argument used by advocates of railway nationalisation is that the credit of the State is superior to that of private companies, and that therefore the State could borrow money at a somewhat lower rate of interest than the companies for the capital employed in the railways. The inference is that the difference between the rate of interest at which 
Government could borrow and that at which the railways borrow would be saved, and the railways thus worked slightly more cheaply. On the other hand, the increased expenditure which inevitably occurs under Government control (to be referred to later on) would soon more than counterbalance the saving from this source.

Other reasons given for a change by some who recommend State control are that freight rates are thought to be higher than elsewhere, and that preference is given to large traders. With regard to freight rates, in the aggregate they have been falling for many years. Exact comparisons with foreign rates can hardly be made owing to difference of conditions; but having regard to the quicker and more frequent services on British than on continental lines, and the inclusion of cartage in British rates, rates in this country do not seem, generally speaking, to compare unfavourably with those abroad. Some continental State railways charge almost double rates for quick delivery. If the cost of the service is taken into account, private enterprise appears to do better for the public than Government management ; the cost of British railways is much more per mile than the cost of continental lines, and the interest on this cost is part of the cost of service. State control abroad has sometimes led to increased rates, while rates have gradually been falling in the British Isles. The causes which under State control have brought about increases of rates in other countries would have the same effect here.

The undue preference complained of consists of slightly reduced rates for large quantities of certain commodities, generally carried fairly long 
distances at through rates. When goods are carried at through rates it means that they pass over more than one company's line, and that to obviate the trouble of paying the freight separately to each company a through rate is agreed on by the companies concerned, and is collected on behalf of all the companies by the company that delivers the goods to the consignee. A through rate is sometimes equal in amount to the total of the separate rates when added together; sometimes it is slightly under this total. What is called undue preference in this country has a counterpart in Germany on the State railways, where it is the established rule for certain export and import goods. Some of those who advocate State control of the carrying trade, partly on the ground that a remedy would thereby be found for what they consider the unfairness of undue preference, might perhaps find, if Government control were in existence, that other considerations beyond their own points of view caused State administrators as well as private companies to provide such inducements in the form of through rates, a little under the total of the combined single rates, as would enable certain branches of trade to be carried on the existence of which is an advantage to the country. Certain trades and industries would suffer if the present mode, adopted as a result of long experience by the carrying companies, were disturbed. The railways, canals, and steamship lines, with their knowledge and experience of such matters, no doubt render a service to commerce, and increase the trade of the country, as well as their own traffic, by enabling trade to be done in the United Kingdom that would not be done if certain through 
rates were not arranged. Large quantities making full loads can sometimes be carried rather more cheaply per ton than the same tonnage divided into consignments of different sizes. It is, as every one knows, a usual thing in some trades for large orders to be accepted at slightly lower prices than small orders, because the expense per unit is frequently somewhat less in dealing with large quantities. Those who complain of undue preference apparently usually regard the matter only from the point of view of how it affects their own business interests; sometimes a wider view of what is most in the public interest is desirable. If the railways did not give preferential rates of the kind sometimes objected to for fish from the West of Ireland and North of Scotland to large towns and cities in England, some of the fishing industries in these distant coasts would suffer injury or be unable to continue. Some of them, I believe, could not have been established without these rates. The fishery people nearer the large towns naturally dislike their competitors having these rates; but probably they have on the whole more advantages owing to their geographical position than their Irish and Scotch competitors who have these rates. In remedying one grievance another is sometimes created; and in doing a legitimate action for the benefit of one trade or district, another trade or district sometimes considers itself placed at a disadvantage. Government officials, being less in touch with commerce than business men, would generally be less well informed, and have less intuitive knowledge as to the balance of grievances, and how trade would be affected by any change. Grievances alleged in 
connection with reasons for desiring State control of railways and canals can be better dealt with by the boards of directors (mostly experienced business men) and by railway managers than by State officials. If civil servants were dealing with complaints, it would be known that their decisions might be interfered with by means of parliamentary action. The moral effect of the decisions would thus be lessened, and the effect would not be good.

The suggestion that the public would be better served by State railways than they are at present seems rather a hazardous one, and ill-considered,; for Government departments are generally less well managed than large business concerns. This is practically inevitable, for reasons to be given later on. Discussions in Parliament show that departments under the control of the War Office, for instance, have not been well managed. It will be remembered by newspaper readers that scandals in connection with the commissariat became a source of serious trouble after the close of the last Boer War.

The Post Office Savings Bank, too, is managed on principles hardly in accordance with sound finance. If it had to stand alone, dependent solely. on its own resources, instead of having the Treasury and the Consolidated Fund behind it, it could hardly, according to the Investors' Review, continue in business managed as it is at present. The Investors' Review of March 6, 1909, points out that the financial position of the Post Office Savings Bank years ago was so bad that its conductors resorted to the desperate expedient of suppressing its balance-sheet, and that its position grows worse and worse. The writer of the article, 
after mentioning the unduly high price at which the Savings Bank bought Consols, points out that a crowning mistake was made at the end of 1893 in raising the limit of annual deposit from $£_{30}$ to $£_{50}$. Commercial banks at that time, not having the Consolidated Fund to squander, were taking measures to reduce their deposits, by diminishing the rate of interest allowed on them. The invitation of the Post Office Savings Bank to the public to increase the amount of deposits was so largely. availed of, that the Savings Bank had to invest $£ 45,000,000$, and invested this amount in Consols at an average price of 107.73 per cent $;$ an altogether inflated figure for a $2 \frac{1}{2}$ per cent. stock, brought about by the ill-advised action of the Savings Banks as £9,500,000. Whatever the the Investors' Review article calls this inflation of the price of Consols a gigantic bubble blown by the Treasury. Mr. Thomas Gibson Bowles in a recent pamphlet, "National Finance in 1908," estimates the deficiency in the Post Office Savings Bank as $£_{15}, 204,000$, and that in the Trustee Savings Banks as $£ 9,500,000$. Whatever the actual loss may be, the squandered millions now deficient on capital account will no doubt have to be made good sooner or later by taxpayers. Those who realise the incapacity of the Treasury in this matter will hardly wish for further extension of State control.

For reasons practically insuperable Government in this country cannot manage satisfactorily, or control with advantage, undertakings of a business character. One of the great difficulties is to get sufficiently capable men for positions of control, such men are not forthcoming in proportion to 
requirements. Outside the ranks of leading statesmen the service of the State does not as a rule attract men of the best talent and ability. Such men generally devote themselves to private enterprise, where ability has opportunities of greater reward. The regulations and routine virtually inevitable in the case of State control destroy initiative such as leads to enterprise and improvement. While rules and regulations are necessary for large numbers, the discouragement of initiative and the cramping of ability by cast-iron regulations make the State service distasteful to many men of ability. There may be other reasons, too, but these are sufficient to explain why the State service in the United Kingdom does not, generally speaking, attract the best men, while private enterprise on a large scale does. The undertakings of a business character controlled by the State are not generally considered to be well managed; instances have just been mentioned-enough sufficiently capable men are not to be had for State service; how, then, can it be expected that railways and canals would be better managed by the State than by business men?

The existing method of controlling and managing great railways by obtaining the services of eminent and capable mercantile and financial men as directors is a practical and beneficial one. Their knowledge and experience are obtained at small cost, for only a limited amount of their time is required. Such men do better by private enterprise than by entering Government service.

Under State control there is not that healthy rivalry between competitors that makes each endeavour to provide as good a service as possible, 
or a better service than others. It is competition of this sort that leads to improvement and developments which have resulted in the British railway service being in most respects the best in the world. Government departments are, at best, more or less out of touch with commercial needs. This prevents them from knowing promptly what will best suit mercantile requirements. It is common experience that business matters are more quickly. dealt with in private concerns than Government offices.

In addition to these inevitable drawbacks to State control, there is the disadvantage that Government administration is less economical than private enterprise, because those actually expending: the money have not the motive of self-interest to be economical, as they do not benefit by economy. Officials having fixed salaries seldom have an inducement to bring about improvements and economies. In private enterprises those who will benefit by economies and improvements are perpetually on the alert for anything that will lead to financial advantage.

Then the evils of having railway and canal communication partly dependent on politics are serious. In weak or incapable hands, or in the case of a Cabinet Minister without a sufficient sense of fairness and justice, harmful precedents might be created or harm done. If the votes of a section of members were needed to keep a party in power, a Government might be committed to much that would be unwise. The country might be committed to building, keeping open, or working unprofitable lines, for instance, or reducing rates in a way that would affect the revenue injuriously. A Chancellor 
of the Exchequer might be influenced by districts where Government interests needed strengthening, instead of acting in the public interest. The exigencies of the Parliamentary situation might lead to inequitable concessions. In a Parliament of nearly evenly balanced parties a small number of members representing some particular interest might control the Government in time of war or threatened famine, in order to gain their point, although the whole country might suffer thereby. Every one knows there have been instances of groups of members putting some particular interest before the general public welfare; such groups will apparently sometimes go to extremes to gain their ends.

It is clear that under State control there would be liability of trade being injured by carrying out promises made to gain votes for party purposes. Freight rates would be liable to be raised to meet Budget requirements, and trade would thereby be inconvenienced and injured. This happens sometimes in countries where railways and canals are controlled by the State. Thus in a variety of ways the carrying trade and commerce would be liable to be at the mercy of party politics. Political corruption is of course less to be feared in Great Britain than some other countries; but Government control of railways and canals has led to corruption, or something like it, in several countries.

On various grounds it is almost certain that expenditure would increase if railways and canals were controlled by Government. The tendency which brings this about is so great that it would be virtually inevitable. It has happened in other 
countries where government has purchased the railways, partly owing to increased working expenses, partly because of unprofitable expenditure and waste of money which so often occur when those in control have not the personal financial interest which exercises such a wholesome effect in private enterprises. It is by no means out of the question that were the railways and canals acquired by the State in this country, they might sooner or later become a burden to taxpayers, who would have to undertake the risk of loss as well as profit ; and there is also the possibility of depreciation of railways owing to competition of several kinds. In various ways the State at present practically enjoys many of the advantages of control without being burdened with the cost of the railways or the liability of loss upon them.

Has the control exercised by Parliament and the Board of Trade in past years been exercised wisely and with foresight? It can hardly be said that the results, generally speaking, have been satisfactory. Some recent Acts of Parliament have scarcely settled with even a small measure of permanence the matters they have dealt with. It can hardly be said that Governments, whether Liberal or Conservative, have shown capacity for railway and transport problems. On the other hand, the railways, although they have made mistakes, have on the whole done exceedingly well for the country. They have been enterprising and have probably done more than any other agency (except the spirit of private enterprise) to develop and increase trade and industry in this country. Although, however, the railways have done well for the country, they might, under other circumstances, 
have done better than they have for both their customers and shareholders. The enormous growth of traffic in the past thirty or forty years (partly due to the natural development, partly due to the facilities of the railways themselves) has not given the results that would have been possible in the shape of reduced rates and improved dividends. This is partly due to large capital expenditure, some of which was the result of the parliamentary policy of competition that was virtually forced on the companies. It is also partly due to the price paid for labour, for which the railways seem to be paying more than the market value. The Railway News of May 4, 1907, gives particulars showing how generously the men are treated, not only as regards wages, but as to clothes, \&c. That this is realised in the labour market is shown by the fact stated by the chairman of the Great Western Railway at the half-yearly meeting of the Company in February, 1907, that the Company had 19,285 more applications in 1905 for positions among the wage-earners than there were vacancies for. This shows that railway service is attractive to labour, as might be expected from the high wages, privileges, and perquisites. The inference to be drawn from it is that there are not any real grievances, as would be supposed from the speeches of railway workmen at annual congresses. It would appear that they are continually asking for more when they are already better off than other classes of workers. The better course would be for employees who are dissatisfied as public speeches indicate to resign their situations. The control and supervision exercised by Parliament and by the Board of Trade, while beneficial 
in having caused a diminution in the number of accidents and in the loss of life, has put railway and canal companies to great expense in obtaining Acts of Parliament, and in other ways; and it can hardly be regarded as having been particularly wise or good as regards matters of policy. Parliament has more or less supervised railways and canals without safeguarding different interests, as has been done in some other countries. It has taken away the measure of monopoly originally granted (by authorising rate-aided tramways and other competition, for instance) without affording the original lines adequate protection. In numbers of cases companies have to pay rates to help to support competitors that are taking away some of their traffic. That seems hardly an equitable state of things. The Railway and Canal Traffic Act, I 888, affords another instance of lack of fairness. Under this Act a margin to be allowed for the increase of goods rates was fixed, which in some cases works out unfairly at the present time. The maximum rates chargeable were fixed in some cases at the actual working rates, leaving no margin for increases if the cost of working increased; and as these rates were fixed in the early nineties, when working expenses were lower than at present, the result now is unfair to the carrying companies. This eventuality was pointed out to the representatives of the Board of Trade by railway and canal representatives before the rates were decided upon; but the Government, or the parliamentary majority of the time, passed the Bill, apparently irrespective of whether the proposed schedules of rates were a fair settlement and likely to prove permanently satisfactory. 
Parliament has for a generation encouraged railway competition. Partly owing to this encouragement, and partly owing to the exigencies of the times, competition has gone to extremes in some respects. The railways recently commenced steps to stop unnecessary expense due to excessive competition. This move was generally approved. It is competition leading to expenditure in excess of requirements that it is desired to put an end to.

When the Great Northern, Great Central, and Great Eastern railways recently brought a Bill into Parliament to facilitate and ratify joint working arrangements to prevent wasteful competition, the President of the Board of Trade, who had shortly before spoken in approval of the principle, showed reluctance to deal with the question. He threw the responsibility on Parliament and on a Committee, and carried a proposal that the Committee should consider in conjunction with the Bill the general principles that should be adopted as to railway amalgamation. The railway companies, when they found that their Bill was to be burdened with an inquiry of this sort, which might be long and costly, withdrew it ; and the President of the Board of Trade afterwards announced that he would appoint a departmental committee to consider the question of railway amalgamation. There is nothing in the arrangement or amalgamation of interests on the part of the railways that is necessarily a step towards State control.

The questions of amalgamation and competition naturally come under consideration in connection with the discussion of State control; and they perhaps have additional interest at present owing to the Bill for the amalgamation of interests of 
three railway companies having been brought forward.

In this country competition has been the life of railway enterprise, almost through its whole career. It has, however, been pushed so far that it could not go much farther without being within measurable distance of becoming ruinous to those engaged in it. But reasonable, fair competition, where there is room for it, where traffic is large, is sometimes good for the railways and canals themselves, as well as for traders. It stimulates efficiency. Competition having done much to stimulate enterprise, and to improve British railways, and traders finding they are sometimes better served where there is competition (a little is often sufficient for the purpose), it is not to be expected that such a useful agent will be lightly put aside.

Wasteful competition can be guarded against and prevented in several ways. The best way appears to be that chosen by those having most knowledge of the subject-the plan adopted by the railways themselves. Under this arrangement the competing companies agree as to what expenditure is unnecessarily large, and they reduce it to suitable limits. And instead of each company endeavouring to get as much traffic as possible from the others, receipts are to be divided in proportion to past revenues at competitive stations. The arrangement amounts in some respects to the different companies' systems being worked almost as one concern. Traders' interests are safeguárded by the maintenance of facilities and advantages already in existence. The stopping of useless wasteful competition should not injure the advantages derived from competition. Though the rail- 
ways concerned will no longer each endeavour to attract traffic from one another, but allow it to take its most economical course, they will naturally maintain efficiency, or they would suffer from loss of traffic in other directions, for they have sea and canal competition in various places where there is no rival railway. The diminution of competition between railways is less to be regretted from the traders' point of view as independent improved canals are soon likely to come into existence.

Amalgamation in the past has come about mainly because of the difficulty of arranging through routes and through rates when a number of small companies had to be dealt with. The amalgamation of interests which is now taking place has naturally and of necessity come about because competition had become so extreme as to leave practically no alternative, the only. alternative being: diminished efficiency owing to diminishing profits. Had it been possible to push competition to further extremes, the usual standard of efficiency in the case of some lines must have been crippled, poorer train services would follow, and trade would suffer. For this reason amalgamation of interests or some such form of arrangement is in the circumstances inevitable. It is better for traders that competition should not go to the farthest extreme.

Traders sometimes say that agreements between railways and canals are undesirable as they prevent competition; but traders have made agreements inevitable, by causing carrying companies to compete against one another until rates have become unprofitable. And traders, it is said, make agreements of a similar character between themselves. Who 
blames trade competitors for making agreements when competition has reduced profits almost to an unworkable minimum? And why should not carrying companies do the same? It is in the interest of traders, as well as in their own interest, to do so.

As some traders have pointed out, freight rates in the circumstances are very reasonable, and it is a matter of indifference to them whether freights are high or low, provided their competitors have to pay the same rates. An instance will best illustrate how short-sighted traders often are with regard to competition. In a previous chapter it is mentioned that the London and North-Western Railway competed so severely for Grand Junction Canal traffic that the Canal Company were obliged to discontinue their carrying trade. This was a permanent loss to traders. It would have been better for them if, instead of supporting the railway for the sake of cheap freights temporarily, they. had supported the canal, even at slightly higher rates than the railway offered, in order to have permanently the advantages of the canal service, which would have acted as a check on the railway rates.

If we look to the experience of other countries, there is little to be found to encourage the view that State control would be advantageous in this country. For various reasons State control has been adopted and is adhered to elsewhere, but not, apparently, on account of the merits of that method of administration. In the Latin countries and one or two others personal enterprise is not as important a feature of the national character as it is with us. It is largely owing to this difference in national characteristics that Government control takes the place of private enterprise to a 
considerable extent in Latin countries. It is the custom for initiative to come from the Government, and not from private business people living in such countries, and often for railways and canals to be worked as well as constructed by the State. In such countries too it is usual for the more capable men to seek service under the State, instead of devoting themselves to private enterprise.

In the two greatest Anglo-Saxon communities, Great Britain and the United States, the most capable men as a rule devote themselves to private enterprise. This deliberate practice is too satisfactory to those concerned for it to be likely to be changed. Some Governments have felt obliged to provide and work railways because there was no private enterprise equal to the work; and in some instances Governments consider it necessary. to have absolute control of the railways for strategic purposes in the event of war. This is one of the reasons why the State owns the railways in Germany.

Mr. W. M. Acworth, in an address to the economic section of the British Association at Dublin in 1908, discussed the question of State railways and gave many particulars relating to other countries. He stated that in Belgium railways are State-owned mainly because at the time of railway introduction available private capital was not to be found in the country; and the Belgians did not wish their railway system to be controlled by their neighbours, the Netherlanders, who would have supplied the necessary capital.

In Switzerland one of the reasons for State purchase (a few years ago) was of a similar 
character : the capital of the Swiss railway companies was mainly owned by French and Germans ; and partly on account of sentiment, and partly for other reasons, the Swiss people did not consider this a desirable arrangement. Different parties had different reasons for desiring State control.

The Swiss experiment of railway nationalisation has, so far, not resulted as anticipated. The profits expected have not been obtained; and economies that it was predicted would result from unification of the different companies' systems have not been realised. On the contrary, expenditure has considerably increased, and has increased in ways that seem to indicate it will continue to increase rather than diminish: so that loss is expected in future. Promises used in order to help to get State purchase carried have not been kept. Political influence is stated to have been used with injurious results. Salaries have been increased; rates have been slightly reduced; the percentage of working expenses to receipts has risen from 60.98 per cent. in 1902, under private enterprise, to 69.22 per cent. in 1907 under State management.

In Italy, Mr. Acworth stated, the force of circumstances compelled the Government to take control of the railways after the unification of the country. A Commission, however, reported that it was not desirable for the State to work the railways and Government endorsed that opinion; so the French method was adopted, and the lines were leased to three companies. Constant disputes, however, occurred between the Government and the companies, and no one proved capable of bringing about any practicable agreement ; the 
Government, therefore, had to take the railways and work them.

In Australia, Mr. Acworth said, the Governments had to make railways because private capital was not forthcoming. The gold-mines absorbed all that was available in the country. Forty-six miles of the Victoria state railways have been abandoned, he stated, as the receipts were insufficient to pay expenses.

What has been done in Mexico in order to retain the advantages of private enterprise, and at the same time give the Government a voice in the supervision and an interest in the prosperity of the railways, is not only of much interest, but worthy of consideration as a practical example of how Government supervision, if it is thought desirable, may be advantageously allied with private enterprise. Mexico, Mr. Acworth stated, has obtained a fair measure of control by purchasing enough deferred shares to be a majority shareholder. The cost was not great, and coupled with it is a directorship and the obligation to guarantee interest on necessary bond issues. This arrangement gives the Government control in essential policy, and in prospects of profit in future; while the other directors form a useful barrier against political or local influence in uncommercial concessions. The final appeal to the majority shareholder, who is interested in the welfare of the country, instead of to shareholders who are less interested in the country than in dividends, is said to work well.

Mr. Acworth also referred to a quotation from the Montreal Gazette of May 27, 1907, from which it appears that the Inter-Colonial Railway, in 14 
Canada, although it serves a good traffic-bearing country, with little competition during much of the year, is so mismanaged, by means of Government control, that it does not earn enough to pay the cost of working and maintenance, although its gross receipts per mile are equal to those of an average United States railway; and every year it needs a grant of one or two million dollars, or more, from the Treasury to keep it in fit condition for its traffic.

Mr. Acworth recalled that an American statesman, Charles Francis Adams, wrote more than thirty years ago with regard to this question : "In applying results drawn from the experience of one country to problems which present themselves in another, the difference of social and political habit and education should ever be borne in mind. . . France and Germany are essentially executive in their governmental systems, while England and America are legislative. Now the executive may design, construct and operate a railroad; the legislative never can."

Finally, Mr. Acworth referred to the fact that in Anglo-Saxon countries Legislature and Judicature are predominant, while among the Latin races the executive is the most important. And, he said, depending on an enlightened public opinion may be good in theory, but private interests appear to more than counterbalance this. Trusting to public opinion presupposes, he said, that public opinion will be exercised for the benefit of the State ; but admittedly it often is not.

Other foreign experience supports Mr. Acworth's view that State control has not generally been adopted on its merits, and is by no means always satisfactory. 
In Denmark the prospects of fair remuneration on the outlay in some parts of the country were insufficient for private companies, unaided, to undertake railway construction. Government, therefore, had to take control of the railways ; and after that took place several parties with different interests pressed for concessions, and so far succeeded that in 1902 the State railways no longer earned enough to pay expenses, and the following year passengers' fares and goods rates had to be increased in consequence.

In France the net revenue for 1906 on State railway capital was 2.05 per cent. Most of the additional lines built by Government are unprofitable. Further capital outlay is being incurred which it is estimated will reduce the net return to 1.73 per cent. In France, therefore, as elsewhere, the inevitable tendencies of State control appear. When, a generation hence, the existing agreements between the State and the railways expire, it seems probable that even the present small return on capital, which involves a loss that has to be made up out of revenue from taxes, may have disappeared.

When the last large independent French railway was, recently, about to be purchased by the State, the representatives in the Legislature of the districts served by the railway (the Western Railway of France) were strongly opposed to the step. The State was going to work, as well as own, the line. The people preferred company management to State management. The anticipated increase of freights and fares which occurs at times, to help to meet Budget requirements, is a thing much objected to. Senator Charles Prevet, who at the 
request of the Senate made a report on the Bill for the purchase of the line, reported that the purchase would be inopportune and unjustified. $\mathrm{He}$ also reported that the bureaucracy had shown its commercial incompetence in the work of existing monopolies.

In Belgium there is a certain amount of dissatisfaction with the railways, apparently because State management is not as good as company management, and in commercial circles a remedy in the shape of an independent railway between Antwerp and Brussels has been discussed. There is also dissatisfaction with State management of railways in Italy.

The Belgian State railways are sometimes referred to as a success; but M. Peschaud, in articles in the Revue Politique et Parlementaire, for May and June, 1896 , shows this to be a fallacy. These articles are reproduced by Mr. E. A. Pratt in his little book on "State Railways." The chief evils, M. Peschaud states, are excessive centralisation, involving an unduly large staff, abnormal redtapeism, lack of initiative, and lack of proper sense of responsibility. The inevitable tendency to overstaff Government departments, which exists in all countries, is shown by the cost of the staff being 60 per cent. of the total expenditure on Belgian State railways, while it is 47 per cent. on leading British lines.

The endeavour to show a profit on the Belgian railways leads, we are told, to parsimony and false economy, and the omission of ordinary repairs. Low export and import rates, which British and Irish traders complain of as undue preference, are made in Belgium as well as Germany, being 
considered virtually a necessity ; rates for internal traffic are at a slightly higher scale. Except for this difference, the principle of uniformity in rates is acted upon, elasticity to suit particular local conditions being lacking, as is usual with Government management. State-controlled railways are necessarily worked by fixed rules. Exceptions which help to establish and develop trade cannot be made under such conditions because some one else would want similarly reduced rates. "A Cabinet minister would be regarded as unjust and inconsistent who did not give such rates; and a majority of men, whether Members of Parliament or electors, not being conversant with the whole big, complicated question, would say an exceptional rate in exceptional circumstances should not be given. Experience of how such matters are dealt with shows that that would be so," says the writer referred to.

It is alleged by advocates of railway nationalisation that a large amount of expense could be saved by it ; but that plea was put forward by advocates of railway nationalisation in Switzerland and in Italy, and it has been falsified by experience. Government control seems invariably to involve concessions which counterbalance the saving effected at first by unification and centralisation. M. Peschaud states that for 1905 the percentage of working expenses to receipts on companies' railways in Belgium was 45 per cent. and on Stateowned railways 61.97 per cent. On English railways it was 62 per cent. for the same year. These figures show that private enterprise works more cheaply than Government in Belgium, as in other countries; and that the advantages claimed for 
State control are not realised in that country, as expenses mount up to about the same as in England, where several of the chief items of expenditure, including labour, are more costly. State control in England on the same lines as in Belgium would therefore not only result in no reduction, but in increased expenditure, which would lead to increased rates of freight-the very thing that it is desired to avoid, if possible, in the interest of the trade of the country.

The high proportion of expenditure to receipts on the Belgian State railways is stated by $\mathbf{M}$. Peschaud to be partly due to political causes. He says the Belgian Legislature is used by deputies for obtaining increased pay for State servants, to whom they may be indebted for election, and that amendments were proposed by Socialist deputies to the railway budget of 1905 which, if passed, would have augmented salaries and wages by 40 per cent. Government departments, it is pointed out by M. Peschaud, like numbers of municipal bodies, disregard business principles when they engage in undertakings of a commercial character.

M. Peschaud's study of the subject substantially corroborates the view that there are inherent disadvantages of a serious character in connection with State control.

The idea that railways and canals could be managed by Government with more advantage to the public without being a burden to the national exchequer does not seem to have been well thought out. The evidence as a whole does not support the supposition. Unless working expenses can be considerably reduced, any appreciable benefit to 
the public in the form of lower freight rates and fares could only be attempted at the cost of the taxpayers if railways were owned by the State. This would be hardly a real gain; and not only would it be no gain but it would be unfair to make people not in business help to pay freight for traders, for the people who most largely use the railways and canals are by no means the whole body of taxpayers.

State control has been generally adopted in other countries for various reasons that do not apply in the United Kingdom. The advantages attributed to it have, generally speaking, been found more or less illusory or unrealisable when State control has replaced business management. In Prussia, certainly, the Government derives an appreciable revenue from the railways; but this is quite an exceptional case in several important respects, where a well thought out policy has been rigidly adhered to. The capital account has been kept small in proportion to earning capacity, and working expenditure has not been unduly increased.

In this country anticipations of profit from the telegraphs after acquisition by the State were neutralised by subsequent events ; and in such an economical and well-administered country as Switzerland the calculations and promises as to cheaper working of railways under Government control have been found to be illusory. How can it be expected that any better results would follow State purchase of railways and canals here?

Nationalisation of railways and canals would seem to be only desirable if it is certain that it would substantially benefit the country, or if a necessary system of communication could not be 
established in some other way. A greater number of difficulties and disadvantages generally beset State control than private enterprise. Disadvantages inseparable from State control are complained of in countries where it exists. In France, where the subject has been much studied and discussed, it has been considered up to now that it is neither expedient nor profitable for the State to work the railways. Most of the lines are therefore worked by private enterprise and owned by the State, in order that Government may reserve to itself control in certain contingencies.

There is even less to be said in favour of nationalising inland waterways than railways, for they are not used by the whole country. They are not universally needed like roads and postoffices ; they are less widely needed than railways. They can only be useful in some parts of the country. Although it is obviously impracticable to have anything like hard-and-fast rules in such matters, there is considerable amount of fairness in the argument that it would not be justifiable for canals to be constructed exclusively with public money as they are not universally used like roads and posts. Were the State to make and maintain inland waterways many counties would contribute towards what would not benefit them : many agricultural counties would contribute towards canals which were for the benefit of manufacturing districts. For this reason among others it seems undesirable that the State solely should supply the canals that are needed, if they can be provided by other means.

In France, after much attention had been given to the subject, the conclusion was arrived at a few 
years ago that the State should not any longer provide canals and make them toll-free. This decision was come to partly for Budget reasons, and partly because it was considered hardly fair to many districts where there are no canals that they should be taxed for making and maintaining waterways in other parts of the country; and a law was passed, as already mentioned, that canals should only be constructed in future if the local authorities concerned contributed half the cost.

There is no reason to think the work of canal improvement cannot be done by private enterprise. There is capital and energy enough in Great Britain to do all that is wanted. Money is always to be had for useful enterprises with a sufficient prospect of a fair return on the outlay, ; and it will no doubt be forthcoming for canal construction and improvement at the right time, provided there are proper safeguards insuring fair play for the waterways.

Nationalisation of railways and canals, if handled no better than the affairs of the Post Office Savings Bank or Irish land finance, might cause serious inconvenience. The bad state of Irish land finance shows the inaptitude of Governments and the Treasury for dealing satisfactorily with large financial questions. The undertaking would be an exceedingly large one, especially for a nation whose financial reputation is somewhat impaired by its Irish land finance. And the undertaking would not be without serious risks after a few years.

The balance of argument is not in favour of State control, nor have the arguments advanced in its support been adequate or convincing. England's foremost position in the commerce of the world has been attained by individual initiative 
and private enterprise. It is private enterprise that makes things succeed. It is private enterprise (together with other characteristics of the Anglo-Saxon race) that has made-British commerce an immense success. Experience shows that private enterprise beats State enterprise under equal conditions. Nothing leads to successful and satisfactory results for the various parties concerned so much as the stimulus given to private enterprise by the prospect of individual benefit to be gained as a result of exertions. Private enterprise is so valuable to the country that, while properly safeguarding public welfare and individual liberty, it should not be crippled or fettered so that its vitality will be impaired.

National character, past history, and habits of independence all indicate private enterprise as the method that bests suits British people. This country still depends, and must depend in future, on the same element if it is to maintain its position. All the great commercial successes, all the great enterprises of a business character have been achieved through the stimulus of private enterprise. Commerce would have little chance of success if tied up with the rules and red tape of Government departments. Government control as a rule checks enterprise, checks advance and improvement, and the position under it becomes " stereotyped."

It is almost inconceivable that Government-controlled railways would have done as well as private enterprise for British commerce during the past sixty years. Parliament seems seldom to take a thorough grasp of inland transport questions. Perhaps the chief instance of this is that it failed 
to preserve inland water competition, which is the best of all means for keeping in check disadvantages that may arise from railway monopoly. Private enterprise takes more risk than Government, and is more sagacious in its choice of risks. It is better than State management because it is controlled by men more in touch with trade ideas and requirements than men who are often elected or appointed for political reasons, or as a reward for political services. For this reason there is in various quarters a well-grounded feeling against municipal or local authority control. In Manchester municipal action with regard to the ship canal has been beneficial; but that is a very exceptional case in several respects. Birmingham has spoken against municipal control of canals. Generally speaking, municipal interests are too local for canals to be under such control. Similarly, but in a lesser degree, County Council control is open to objection. Local authorities, as a rule, are not very representative of commerce. In both cases members are often selected because they, belong to a particular political party, not because of their capacity or aptitude for dealing with public business. Trusts, too, however carefully composed, have not the advantages of private enterprise. In some cases they certainly work well; but the principle on which they are based does not admit the stimulus of private enterprise. The Weaver Navigation Trustees have done excellent work, and the Liverpool Harbour Board is highly spoken of $;$ but boards of trustees such as these may not be to be had in every part of the country. 


\section{CHAPTER VIII}

\section{IRISH INLAND WATERWAYS I}

THE conditions and practical possibilities are not the same in Ireland as in England and other countries having large commerce and manufactures. England has an immense traffic in connection with numerous extensive industrial districts, seaports, and collieries. In Ireland, on the contrary, there is such an absence of commerce and manufactures, except in a few limited localities, that were canals enlarged, cargoes sufficient to fill larger boats would seldom be forthcoming. England having an annual inland waterway. tonnage of over thirty-five million tons, it is worth while to enlarge some of the canals along principal trade routes in order to get cheaper freights ; but Ireland having an annual inland waterway tonnage of only about three-quarters of a million tons, it would not be profitable from any point of view to enlarge waterways and locks, even if a liberal allowance was made for possible increases of traffic in the future.

There does not seem at present to be much prospect of any development of traffic that would

x This chapter is mainly taken from a memorandum submitted to the Royal Commission on Canals, and has been revised. 
justify lengthening Irish canal locks, which would be the least expensive method of providing for larger cargoes. In the event of the manufacture on a large scale of compressed peat fuel, the traffic alone would not do so. Harvest traffic is occasionally available in large lots, but the quantity is decidedly limited. Further development of Ireland's resources may lead to more home production for home use, but it is hardly likely appreciably to increase traffic. And agriculture, however much it may be improved, is not likely to give much more traffic, unless grain crops again become more profitable than live stock. Even in that event, it is hardly likely that corn added to other traffic would be sufficient to make lock enlargement worth undertaking. Agriculture, as a rule, gives much less traffic than merchandise and manufactures.

Irish carrying companies as a rule do what they can to facilitate and increase traffic; it is to their interest to do so. In the past twenty years on the Grand Canal system new stations, increased storage, additional services, a larger supply of barges, many new through rates, and various other improvements have been provided; and the average rate of freight on the tonnage over the waterways used by the canal company has been reduced more than a shilling per ton in the same period. This shows, notwithstanding statements made on public platforms and in letters in newspapers, that much is being done to facilitate traffic and provide reasonable freights. Looked at from a business standpoint, it is difficult to see how freights can at present be much further reduced in Ireland in any other way than the carrying companies adopt, viz., by making use of all practicable 
improvements and economies as they become available, and making such reductions as they can afford to from time to time.

Although Irish canal traffic is insufficient from a commercial point of view for lock and boat enlargement, there are some improvements of other kinds that would be of advantage if carried out, such as the canalisation by means of the French movable weir system of certain rivers which suffer from floods. The movable weir system could be applied with advantage to the Rivers Barrow, Suir, Nore, and Bann. This system was designed by French engineers to deal with the same problem that is troublesome in Ireland, viz., the prevention of floods from navigable rivers in flat country.

The River Barrow, canalised from tidal water to Athy in the early days of canal-making, has a considerable traffic, having a number of mills, malt-houses, and good business towns along its banks. It is subject to high floods, which interrupt barge traffic, and which are much complained of, especially in the watershed of the Upper. Barrow, where some hundreds of acres are not infrequently under water for many days at a time. Lower down the river, also, both houses and land in various places suffer from the floods. There are more weirs and locks on the Barrow than would be necessary if the river were now being canalised; they could be somewhat reduced in number if the new system of weirs were adopted.

The Suir is a river well adapted for canalisation. It has on its banks some good business towns and some manufactures. Although used for goods traffic for several centuries, it has not been canalised, but only improved from time to time, 
quite inadequately, in various minor ways. Carrick-on-Suir, Clonmel, and Cahir business people desire to have the river properly canalised. Barge traffic from Waterford to Clonmel (population 10,167$)$ is pluckily carried on under considerable difficulties, owing to shoals and shallow water at some seasons and floods at others. Above Clonmel are the town of Cahir and the villages of Ardfinnan and Golden. Higher up, the small city of Cashel is only about two miles from the banks of the river. Low-lying lands between Cahir and Golden, and houses in Cahir and Clonmel, suffer considerably from floods.

The canalisation of the River Nore from tidal water at Inistioge up to Kilkenny was commenced in the eighteenth century, but the money voted for the purpose having come to an end before the completion of the work, the undertaking was never finished. The work done has not been maintained. Traffic used to be carried as far up as Thomastown, but the river getting silted up became unnavigable, and boats now go no farther than Inistioge. The Nore is well suited for canalisation. The floods in the river are not so injurious as those in the Suir and Barrow, the river being smaller.

Two advantages, the provision of transport routes and the prevention of flooding, are obtained from the movable weir system. Hitherto, retaining the depth of water needed for navigation has sometimes meant increasing the flooding of land; and methods of diminishing flooding, such as lowering the solid fixed weirs, usually meant a lessened depth of water for navigation. Now that the use of movable weirs has made it practicable 
to benefit both interests, without injuring either, the canalisation of the Suir to Cahir, or Golden, or Cashel, and the Nore to Kilkenny, and the application of movable weirs to the Barrow, are perhaps, worthy of consideration. While opinions may differ as to whether the results to be gained would be worth the cost, it would be a certain advantage to the towns on these rivers to have efficient navigable waterways. Clonmel and Kilkenny, business centres of some importance, are the two largest inland towns in Ireland outside Ulster.

The greater part of Ireland being well adapted in most respects for inland waterways on account of the flatness of the country, its plentiful water. supplies, the frequent absence of ice in winter, and the partly ready-made navigable channels provided by the rivers, it almost seems a waste of natural resources not to carry out the improvements which would make the rivers increasingly and permanently useful, instead of a means of injury, whenever the rainfall in certain districts is much above the average. Unfortunately, there is not traffic enough to justify, from a business point of view, carrying out new projects that otherwise have something in their favour. The benefits likely to accrue from them would not be commensurate with the cost ; but some advantage could be gained, at substantially less cost, by removing shoals, islands and sandbanks, and deepening the channels where desirable throughout the greater part of the rivers. A large part of Ireland being flat, the rivers have little fall, and become silted. Clearing away shoals and sandbanks would allow floods to pass away more quickly than at present, and 
the interruption to navigation would be lessened. Were this being done, it would be worth while at the same time to make the cross-sections of the rivers more regular throughout, so as to cause a more even and steady current, and thus diminish slack water, which would lessen the liability to the formation of sandbanks. This has been done with great benefit on some of the French rivers.

Few new canals, if any, seem needed now in Ireland, if judged by their probable capacity for yielding a return on the outlay. The following three projects, however, have something to be said in their favour: from the Shannon Navigation to Strokestown, Co. Roscommon, about $3 \frac{1}{2}$ statute miles; from near the junction of the Lagan Navigation with Lough Neagh to Lurgan, Co. Armagh, about 2 statute miles; and the restoration of the western end of the Ulster Canal, from Clones, Co. Monaghan, to Lough Erne, about 8 statute miles.

The proposed Strokestown extension has this recommendation : that the town is only $3 \frac{1}{2}$ miles from an existing steamer route, while it is 8 miles from the nearest railway-station, and io miles from Longford, the station from which goods are carted. From Kilglass Lake (an expansion of the Shannon) to the foot of the town the contour of the country is favourable for making a canal. It is rather a neglect of natural advantage for Strokestown not to be connected with the waterway near it, which would give it communication with Dublin, without the cost of ten miles of road cartage now incurred. Although present arrangements may be against the extension, this, the natural route for Strokestown, if available, would, no doubt, soon 
be used for a large part of the traffic, on account of its greater economy.

The extension from Lough Neagh near the end of the Lagan Navigation to Lurgan, the route for which was surveyed and decided on in bygone years, has not yet been made. The route, only about two miles, is a favourable one for a canal. Lurgan (population I I ,782) is a prosperous linenmanufacturing town, which has latterly increased its manufactures. Although the railway-station is alongside the town, and the waterway two miles distant, some traffic goes to the town by the water route. The amount would naturally increase if this short canal were made. When so near the waterway it would be better for Lurgan to have the full advantage of it.

The western end of the Ulster Canal is derelict for about eight miles, from Clones to Lough Erne, owing to the failure to a large extent of a Board of Works water supply scheme (the Quig Lough supply). With an adequate water supply, which is reported by engineers to be capable of being provided, the restoration of these few miles of canal would connect Lough Erne with the Lagan and Ulster Canal system. Lough Erne is a navigable waterway 36 miles in length (including the connecting river between the two lakes), capable of giving considerable goods traffic in connection with the towns of Enniskillen, Belleek, and Belturbet if a suitable steam-tug service were worked on the lake in connection with barges to and from Belfast. The matter has sometimes been discussed in Enniskillen. If merchants and traders in that town formed a small barge company, and it were properly supported, it should be successful. 
The reconstruction of the derelict Ballinamore and Ballyconnell Canal, in Counties Cavan and Leitrim, connecting Lough Erne and the Upper Shannon, although sometimes suggested, does not seem as though it would serve any useful purpose. The canal was begun after the famine of 1847 , and when opened about ten years later, two or three barges travelled on it, but it has, I believe, not since been used commercially, although kept open for a number of years. The traffic anticipated by its promoters made no appearance. For many years it has been of use only as a drainage channel. The country it traverses is poor and thinly peopled. Local traffic requirements are now supplied by the Cavan and Leitrim Light Railway. Ballinamore and Ballyconnell are small villages, together having a population of only a few hundreds. The restoration of this canal used to be advocated in order to connect Ireland's northern and southern waterway systems, thus making them more complete. Completeness of that sort, however, hardly is a sufficient object when there is no need for the canal from a traffic point of view. It cannot be said to occupy a trade route apart from local needs, which are far too small for a canal. There is exceedingly little traffic that this route would be used for, if available, between Ulster and farther south. The great bulk of the traffic other than passenger in Ireland goes to and from the seaports. The principal Irish seaports each have districts of their own, the chief exports and imports of which pass through them. Each inland district of this sort does somewhat the same class of trade as the others; and these districts as a rule have little traffic with each 
other compared with their traffic to and from the seaports. For these reasons there is no traffic route, worth considering as such, along the line of this derelict canal. Belfast traders have advocated the reconstruction of the canal; but the amount of trade available for it would be infinitesimal. The barge service consequently would be so infrequent as to discourage traffic.

Other canal projects have been mooted from time to time such as from Ballinasloe Canal terminus to Mountbellow, Co. Galway $;$; from Corbally terminus to the Curragh of Kildare ; from Mountmellick to Maryborough, Queen's County ; from Kilkenny to Castlecomer collieries ; and some others. A cheaper way of bringing coal from Castlecomer collieries than by canal would be by aerial wire tramway, as is done in some other places; but the comparatively small traffic and other conditions (the coal is anthracite) make it probable that carts or road motors would be the cheapest mode of transport for this traffic, if private enterprise had to bear the cost.

There is hardly one of the projects mentioned in this chapter, except the canalisation of the River Suir, and the short extension from Lough Neagh to Lurgan, and perhaps the restoration of the western end of the Ulster Canal, that would be likely to be undertaken on its merits in other countries. Things are, however, done in Ireland that one does not find done elsewhere. It is proverbial that " two and two don't always make four in Ireland." In some instances one of the best tests as to whether projects of the kind mentioned here are worth carrying out would be to make them depend on whether County Council guarantees of small rates of interest on the capital would be given. 


\section{CHAPTER IX}

\section{CONCLUSION}

So far as England is concerned, the canal problem is this : Is it worth while to modernise the canals along the chief trade routes? The evidence in the preceding chapters I think shows that it is. Other commercial countries consider that the benefits obtained from efficient inland waterways are commensurate with the cost. A similar conclusion is to be drawn from the Aire and Calder and the Weaver, the only modernised waterways in this country. It will be remembered that the cost of transport on the Aire and Calder is only about onetenth of that on well-managed canals of the old type.

The canal question has long needed solution. It is of importance to England because of her immense trade, and because of the influence of cheap transport on trade. Engineers say large improved waterways are practicable in England. There is traffic enough to make them pay. There is no reason, therefore, why cheaper freights should not be had on a number of the present canal routes, when the waterways have been enlarged.

Two things are required : cheaper freights, and some means of preventing injury to waterways 
from railways endeavouring to get all the traffic they can. Modern canals, with the assistance of legislation, can supply both these requirements. Efficient canals are a double remedy for alleged unreasonable freight charges, because goods can be carried on them at less cost than by any other means of inland transport; and because any traders having sufficient traffic to make it worth doing, who think freight rates too high, can become their own carriers and carry goods in boats of their own on the canals. Small traders could co-operate for the same purpose. At present traders have boats and barges on canals to a considerable extent, but there is scope for more traffic of the kind. Many traders by adapting their transport arrangements to suit their particular trades can do better by having boats or barges of their own than by any other transport arrangement.

The world of commerce and industry is in favour of inland waterway improvement. Apparently, the only opponents are those interested in railways. Their opposition is not disinterested ; and there do not appear to be any valuable facts to which they can appeal in support of their disparagement of canals. Although some railway representatives have virtually admitted the economy of canal transport, railway opinion is hardly likely to come round to the side of canal improvement. But a change in the railway attitude towards canals might very well be made. The immense increase of traffic during the past thirty years has somewhat altered the position of things. Some of the railways, whose original pairs of lines could presumably no longer safely and conveniently carry 
all the traffic coming to them, have built second pairs of lines alongside their main lines in order to carry the greatly increased goods traffic. In Prussia, where the State owns both railways and canals and is unbiassed, canals would have been enlarged, instead of railway lines doubled, in similar circumstances. Natural growth of traffic may perhaps, again, cause the question of further doubling of railway lines to be raised. It might, perhaps, be to the interest of all concerned that the work should not be undertaken until it has been shown by adequate ton-mile statistics, such as those used in the United States, whether railways make any profit on heavy traffic after permanent-way and rolling-stock maintenance are taken into account. Judged so far as may be by the inadequate figures available, it appears possible that English railways carry at unremunerative rates coal which could be profitably carried on efficient waterways at lower rates. If this is so, it is economically wasteful, and no one gains anything from it, while railway companies and coal consumers lose. But this point cannot be demonstrated in a way that all parties concerned could not refuse to accept without adequate ton-mile statistics. It may be that the very large tonnage carried by the railways sufficiently reduces the average cost per ton as to show a profit. If, however, this is so, it does not make the costlier, mode of transport the cheaper one. There can be no doubt that under approximately the same conditions a modernised inland waterway in England can carry merchandise profitably at lower rates than a railway.

Where the traffic is large enough there is 
nothing in the special circumstances of this country to make improved waterways unsuitable, or nothing that would make the desired results unattainable, provided the waterways are properly safeguarded from unfair and aggressive treatment. The large volume of traffic available on the most important canal routes is sufficient to counterbalance disadvantages such as the country being less level than in many canal districts abroad, and the coasting trade of Great Britain is hardly a sufficiently widespread factor to make inland waterways unnecessary, as has been suggested. It is true, England has a greater mileage of coast line than France, and six or seven times as many first-class seaports. She also has a much larger coasting trade, some of which is in competition with the railways, and has an effect on inland freight rates; but the coasting trade does not appreciably help the large manufacturing districts in the Midlands and elsewhere, which would be greatly helped by efficient navigable waterways.

The railways and canals have, perhaps, each done what might have been expected of them under the circumstances. It is natural that powerful companies should take steps to get all the trade they can for themselves. It is what other business people often do. But Parliament ought long ago to have taken action to make canals as useful to commerce as they can be.

The considerations set forth show beyond reasonable doubt that it is in the interest of the country that improved canals should be made where the traffic is large enough. The late Mr. James Abernethy, M.Inst.C.E., told the parliamentary Select Committee of $188_{3}$ that there were no 
engineering difficulties in enlarging the canals. The late Mr. L. F. Vernon-Harcourt, M.Inst.C.E., has said the same thing. Mr. Bartholomew, M.Inst.C.E., and Mr. Saner, M.Inst.C.E., have also expressed views of a similar character to the present Royal Commission. These opinions are sufficient evidence on the point. It is safe to say that there need be no financial difficulty about the matter, if proper safeguards are provided. The Aire and Calder Navigation Company have had no difficulty in raising capital on moderate terms for improvements.

England is well supplied with railways : there is therefore, perhaps, less need for as large a mileage of improved canals as might otherwise be desirable. The railways are in possession of the bulk of the goods traffic, and they are doubtless in contact with the chief sources of traffic to a greater extent than the waterways. A mode of transport is thus already in existence which, though not the most economical for goods, is required for passenger traffic, and is able to carry all the goods traffic as well, to and from many towns whose traffic and traffic prospects are not large enough to make it an economical proceeding to provide them with waterway communication.

The railways doubtless will continue to be opposed to inland waterways. A railway advocate, Mr. W. M. Acworth, stated in the article already referred to that even if the English Government engaged in competition with the railways, the railway companies would, sooner than lose the traffic, cut their competitive rates to a point where the canals could not follow them. The traffic, he wrote, would still go by rail, and the taxpayer 
would be paying the interest, while the new canals would be as empty and useless as the old ones are to-day. This prophecy is certainly of some interest in connection with the course of events in the near future. If $\mathrm{Mr}$. Acworth is correct, canals and canal transport ought to be protected from over-powerful rivals.

Perhaps the railway authorities can hardly be expected to alter views they have always held on a matter of this kind. Yet the railway policy. as to canals might very well be modified. The beneficial effects of the Manchester Ship Canal upon railway receipts show that the development of trade by means of low freights reacts favourably on railways in England, as well as in Germany and elsewhere. The traffic by rail between Liverpool and Manchester nearly doubled in amount in the twelve years after the opening of the canal. Similarly, but on a smaller scale, Leeds has benefited by the cheap freights on the Aire and Calder Navigation. Increased prosperity results in more people being employed. The additional people employed require houses, food, clothes, and other things. They spend wages and salaries on these, and thus other industries benefit. The additional earnings primarily due to cheap water freights pass through so many hands that the whole community, including the railway companies, derives benefit.

As long as the railways, in their endeavours to increase their own traffic, have power to thwart inland waterway enterprise by making it unprofitable (as they did in the case of the Manchester Ship Canal and the River Severn) there cannot be sufficient security to make investment in canals 
attractive. It seems likely the railways may continue to do this, if past experience is a guide. At any rate, it would be liable to happen if not prevented. It is by no means certain that the railways in the present state of things are doing what is best for themselves in opposing inland waterways. It is to the interest of commerce and the country generally that the railways should be prosperous, so that they may be efficient. It is generally the case in England that the more prosperous a railway is, the more efficient it is and the better it serves the public. Efficient railways are so important to the country that nothing should be done that will cripple their efficiency.

Railway shareholders need not be apprehensive that serious harm is likely to be done to their interests by improved canals, for the amount of traffic that may be taken by waterways from railways is not large in comparison with the whole goods traffic of the railways; and the traffic that would go to canals, heavy traffic, is the least profitable part of it. The increased trade caused by cheap water freights soon recompenses a railway for traffic taken by a canal. The beneficial effect of the Manchester Ship Canal on railway receipts and the advantage of waterways to railways elsewhere show that modern canals in industrial districts so increase trade and prosperity that the railways after a short time are benefited by them. Improved canals being only advisable where large amounts of traffic are to be had, they will, when made, only compete with certain portions of railways, leaving a very large railway-mileage with no more waterway competition than at present. The change that takes place when heavy traffic 
of low value, that cannot well afford to pay for rapid transport, is transferred from railway to waterway is beneficial to the former in two ways. The railway benefits by losing its least profitable traffic, some of which is perhaps unprofitable, and by gaining instead better paying traffic of higher classes, which soon comes from the increased prosperity caused by a modern waterway. And, secondly, railway expenditure is reduced by the smaller cost of maintenance of the line and rolling stock when heavy traffic is lessened. The actual value of such points as these is to be seen when adequate ton-mile statistics are kept. Without ton-mile figures it is probably seldom realised what the money value of changes of the kind amounts to.

At various times Parliament has been appealed to by commercial people regarding carrying trade regulations and freight, but in this country the actual cost of carrying different classes of merchandise is not known, owing to the lack of tonmile statistics; and probably it may be partly for this reason that no principle has been adopted which has provided a lasting settlement. The Railway and Canal Traffic Act, I 888, for instance, was in favour of one interest, regardless of sound principles and of fairness to other interests. Railways have lowered their rates to a level that some of the unfavourably circumstanced old canals cannot go to. The diminished success and reduced efficiency of many English canals is due to aggressive railway competition. Excessive competition of this kind has gone so far that the waterways are unable, to a large extent, to perform their proper functions for traders. When this is 
the case it seems time that the action of the overpowerful competitor should be regulated by law in the interests of commerce.

Legislation of past years that was intended to encourage canal transport has been of little use for that purpose, because the railways have been able to make unduly low rates to capture canal traffic, thus making waterways unprofitable. As matters stand at present, railways have still this power. In certain circumstances the railways might adopt this policy, towards improved canals. As they adopted it with the Manchester Ship Canal and in other cases, they might adopt it on a larger scale, over a larger area, elsewhere. At all events it would be possible for harm to be done in this way. Competition of this sort, if not prevented, would either stop capital for canals being subscribed or make it unprofitable afterwards. The only way this matter can be dealt with is by legislation. It is hardly a desirable state of things that over-powerful rivals should reduce their rates so much on parts of their routes that they carry at a loss in order to get the trade of their small rivals, thus crippling them to a sufficient extent to make their competition ineffective. It is carrying competition too far, and it kills that healthy competition that is frequently, useful. The financial resources of the railways are so great they can afford to make sacrifices on parts of their lines in order to attain their objects. If one mode of transport gained traffic from another owing to its use of superior economic methods, such a change would be inevitable; but for over-powerful companies to injure permanently small rivals that can be exceedingly useful to commerce seems hardly 
in the public interest. Such a thing has been carefully guarded against in Holland, France, and Germany. If deprived of the power of injuring inland waterways, railways would still benefit from the results of waterway development, traders would get the benefits of reduced rates on enlarged canals, and the canals could do their work efficiently and free from injury.

It may be asked, Does not the railway strategy which harms waterways achieve the object in view, viz., a reduction in inland freight rates? Sometimes it does so temporarily, sometimes permanently. When it does so permanently, the reductions in rates are not likely to be as much benefit to traders as the reductions derivable from enlarged canals. And when the reduction made by the railways is only temporary, the advantage can only be slight; for when the competing carrier can no longer afford to carry at unprofitable rates fixed by the railway, and is obliged to retire from the contest, railway rates are generally increased.

No permissive scheme to protect canals would be likely to be successful. It would be better that what is to be done should be provided for in a way that will insure the carrying out of the project. It would hardly be fair to the railways to make canals toll-free; nor would it be in accordance with the fitness of things in a country where private enterprise prevails. Neither would State ownership and working the lines by private enterprise meet the needs of the case. This plan has some of the disadvantages of monopoly, as is found in France.

The needed waterway enlargement can only be brought about by Act of Parliament. Legislation 
on new lines is needed. Besides providing for the improvement of canals, they should be put in such a position that they cannot again come under any control that will lessen their independence and efficiency. Private enterprise alone cannot bring this about in the present circumstances; if that had been feasible, it would no doubt have been done before now.

In some circumstances it is possible it might not be sufficient to rely on improved canals being able to carry more cheaply than railways in order to maintain their independence; but this is an unlikely contingency. Some measure, however, might be necessary to insure security for inland waterways. This may be done by making it illegal for a railway, where in competition with a waterway, to reduce its rates to lower than, say, 20 per cent. above the waterway rates, unless corresponding reductions are made all over the railway company's system. Some such step would seem to meet the requirements of the case. The figure of 20 per cent. above scheduled waterway rates, below which railways should not reduce their rates where there was waterway competition, would, if adopted, be applicable to modernised canals, not to old, unimproved ones. Rate agreements between railways and improved waterways are probably seldom made, and are less likely to be made than agreements between railways and old waterways whose rates more nearly correspond. Large and improved waterways are able to stand on their merits, and are more independent than the old canals.

Exceptional cases require exceptional treatment. As inland waterways are capable of benefiting commerce largely, it seems reasonable that they should 
be treated in a way that will best achieve the object in view. There are various precedents for exceptional treatment of particular cases; the expenditure on Suez Canal shares and on Irish light railways are instances. It has been urged that public money should not be used to compete with private enterprise, and that it should not be used for purposes not benefiting the whole country, especially as those competed with supply some of the public funds. It is, of course, undesirable that the State should compete with private enterprise where the latter prevails;; but there does not seem to be any sufficient reason why it should not give assistance to inland waterways, just as it does to other semi-public works for the general good. The State assists, and sometimes pays for altogether, necessary or desirable works that are of little or no advantage to many parts of the country, which are, however, desirable in the interests of the country as a whole, or some part of the country, and are such as private enterprise, unaided, could not undertake. Among instances of State expenditure of this kind are the road to Holyhead, the Crinan Canal, and Kingstown harbour. There can hardly be reasonable objection to the principle of State assistance to inland waterways ; it has been already admitted in the cases of the Caledonian Canal, the River Shannon, and the Indian canals. And the principle of Government guarantee also has been admitted in India and Ireland. When part of the country can be helped, and the trade of the country thus increased, the fact that other parts of the country cannot be helped in the same way, although taxed equally, is no reason why help should not be given where it will be beneficial. 
Private enterprise, suitably assisted financially by Government and by county and municipal councils, could do all that is needed, apart from legislation, probably with as little expenditure as in any other way, perhaps with less. The plan adopted when Government assistance was given to Irish light railways is particularly applicable to a country like England, where private enterprise is the most suitable and succeeds best. The Government and county authorities guaranteed equal rates of interest (in a number of cases each guaranteed 2 per cent.) on the capital required. In a few cases the Government made a free gift of the capital needed. The essential part of the arrangement was that Government guaranteed a certain rate of interest on certain conditions, the principal of which were that the county authorities guaranteed a similar rate, and that a certain service of trains was to be maintained. The light railways were handed over either to existing companies, to be worked by them, or to new companies which were formed to construct and work them.

The Government under this plan would have to find no capital ; there would be no likelihood of the money market being disturbed; the amount of money to be paid in respect of guarantees could not be very large; the canals would in all probability earn the full rate of interest guaranteed, and the guarantors not be called upon to pay anything.

The general results desired can probably be as well arrived at as in any other way by utilising British credit, and canal organisations already in existence. By utilising the nation's credit (that is, by Government and local authorities concerned 
guaranteeing certain rates of interest on the money required), the necessary capital can be obtained. And by utilising: some of the principal waterway companies, some of them reorganised, amalgamated, or augmented, the machinery for the work of improvement would be in experienced hands, and the work could be carried out with as little delay as may be.

As the State and county and municipal councils benefit from increased taxable and rateable value of trade and property due to development of communications, it is reasonable that they should contribute to the work of improvement. The community benefits by good transport systems, for they increase trade and employment. Poor rate is thus lessened, while additional rates and taxes are received by the authorities. In England there are several precedents for local authorities spending money on navigable waterways. In several countries abroad it is part of the established order of things. Manchester Corporation provided for raising the capital needed to complete the Ship Canal. Exeter Ship Canal was made altogether by the city of Exeter;; Beverley Beck was made navigable by the Corporation of Beverley; and Chichester Canal was financed by the Corporation of Chichester.

Representatives of several local authorities expressed to the Royal Commission disclination to favour local contributions to improved waterways. This may be, and probably was, because they wish first to ascertain what recommendations will be made by the Commission, and what other local authorities and the Government are likely to do. It is natural that they should hesitate about com- 
mitting themselves in a matter of the kind when unaware of the nature of the project to be proposed. Probably many local authorities concerned would be willing to contribute to a well-considered scheme, or guarantee interest on a certain amount of capital, as Manchester Corporation did, rather than let their districts lose the benefits of modern waterways. Time has shown how greatly Manchester has benefited by her wise foresight. It is proverbial that " what Lancashire thinks to-day, England will think to-morrow"; so when the time comes for action, local authorities probably may see the desirability of following in some degree the example of Manchester.

There seems special reason to expect State assistance for the waterway system in this country, as Parliament by allowing railways to acquire and control canals stopped the canal system from developing. The State being thus responsible, or partly so, for the present condition of things, it would seem right that Parliament should now undo the harm done as far as can be.

Of various ways of carrying out canal improvement that have been proposed, several seem to be open to objections already referred to. The ways here pointed out seem to have more to recommend them. But however waterway improvement is effected, whether by assisted private enterprise or by boards of trustees, it is desirable that it should be done ; for it would do much to remove or allay dissatisfaction with inland freight rates, and would do something towards lessening foreign competition, as it would lessen the cost of raw materials: but its chief benefit would be to the internal trade of the country. 



\section{POSTSCRIPT}

SINCE the foregoing was written the Royal Commission's Report has been issued. As regards essentials and matters of principle, the chief point of difference between the Report of the majority of the Commissioners and the recommendations made here is that the Commissioners recommend State control of the enlarged waterways proposed to be constructed, while in these pages private enterprise financially assisted by the State is proposed, and reasons given in favour of it. Permanent illness prevents my writing more as to the Report of the Commissioners.

NOTE

THE publisher much regrets to record the death of the author, which occurred while the work was in the printer's hands, Hence the book possibly lacks the careful revision which he would have given to it.

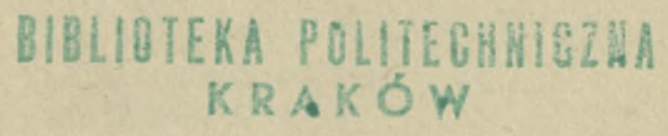




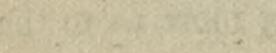




\section{INDEX}

A

Abernethy, James, 232-3

Acworth, W. M., 66, 75-83, 90, 179, 207-10, 233-4

Adams, Charles Francis, 2 ro

Aire and Calder Navigation, 20-3, 59-63, 86, 103, 168, 170,

229, 233-4

d'Aire et de la Deule Canal, I73

Amalgamation with railways, proposed, 203-6

American Canals, $8 \mathrm{I}-2$, $\mathbf{I}_{42}-5^{2}$

Anderton lift, the, I75

Apjohn, Mr., I8I

Ashby-de-la-Zouch Canal, 27-8

D'Aubuisson, M., I6r

Australian State Railways, 209

B

Ballinamore-Ballyconnell Canal, 227

Ballinasloe Canal scheme, 228

Barges, I63-7i

Barrow, River, 222

Bartholomew, Mr., 53, 59-60, I70, I77, 186, 233

Belgian Canals, I09, I38-42, I54

Belgian State Railways, 212-4

Berlin-Stettin Canal, 124

Beverley Beck, 242 
Birmingham Canals, $19,27-8,85$

Boats, see Barges

Bourgoyne, Canal de, 84-5

Bowles, T. Gibson, I96

Brassey, Lord, 43

Bridgewater Canal, I8, 85

British Canals, 18

British Canals: is their Resuscitation a Failure? see Pratt Brussels-Charleroi Canal, I40, I73

Building and Maintaining Canals, cost of, $47-9$

Bury, O. R. H., 66, 70

C

Caledonian Canal, 240

Canadian Canals, I 46

Canadian State Railways, 2 Io

Canals, prior to railways, I8-9; effect of railways on, I920, 23-4; gauges of, $22-3$; desire to improve, 43-4; cost of building and maintenance, 47-9; cost of vessels, 49-51 ; cost of transportation, $5^{8-9}$; speed, 73-4; drawbacks of, $83,90-2$; at big elevations, 84 ; railway-owned, $86-7$; strangulation of, 76,87 ; railway profits on, $92-3$; cost of carrying-on, 97-9; railway investment in, 100; economic advantages of, IOI- 3 ; carriers, $183-5$; general survey, 229-43

Castlecomer Canal scheme, 228

Cavan and Leitrim Light Railway, 227

Champlain Canal, $\mathbf{r} 47$

Chichester Canal, 242

Clark, Charles F., 49, 96

Clearing House, necessity for a, I 86

Coal, cost of transportation of, $6 \mathbf{r}$; railways $v$. canals for carrying, 68-7I; transportation in France and England of, $97-8$; in Ireland, 228

Condor, Mr., 49, 53, 60, 96-8 
Continent, see Europe

Corbally-Curragh Canal scheme, 228

Crinan Canal, 240

Cromford Canal, 27-8

Curragh Canal scheme, 228

D

Denmark, State Railways of, 2 II

Derwent Navigation Co., 76

Development and dimensions of Canals, $15^{8-63}$

Dortmund-Ems Canal, 48, I2I-2

E

Economic Fournal, 75-81

Edinburgh Review, 98, 160

Elbe-Oder Canal, I25

Enniskillen Canal scheme, 225-6

Erie Canal, 8I-2, I42-8, I5I, I73

Erne, Lough, Canal scheme, 225-6

1'Est, Canal de, 48, 85

European Canals, 78-80, 84-5, 89-90, 104-55

Exeter Ship Canal, 242

Fay, S., 29, 36, 71-5, 137

Fellows, Morton, \& Clayton, Ltd., 7I, I84

Findlay, Sir George, 49

Fink, Albert, $\mathbf{I}_{5} \mathbf{I}$

Foster, L., 76

France, Canals in, 78-80, 84-5, 89-9o, 106-18, 139

France, State Railways of, 2 II

Frankfort Canal, 127

Freight, advantages of cheap, 10-13, 40-3; comparison with railway, $5^{8-9}, 75$ 
G

German Canals, 78-80, 84-5, 89-90, II8-31, I39

Gibb, Sir George, I8I

Gobert, M., I09, I4I

Grand Canal Co., I85, 221

Grand Junction Canal, 27-8, 34, 59, 85, 87

Grand Union Canal, 87

Great Central Railway, profit from Canals, 92

Great Western Railway, Canal property of, 86

Grierson, Mr., 72

\section{$\mathrm{H}$}

Harbours and Docks, control of, 186-8

Harcourt, L. F. Vernon, 233

Harrison, Sir Frederic, 67

Haulage, 88-9, I7I-4

Hickman, Sir Alfred, 36

Holland, Canals in, 84-5, I3I-8, 139, 155

\section{I}

Indian Canals, State assistance for, 240

Institute of Mechanical Engineers, 57

Investors' Review, 195-6

Ireland, Canals in, 22I-3 ; natural resources of, 224-5 ;

canal schemes of, 228 ; State assistance, 240-I

Italian Canals, 152-3

Italian State Railways, 208

K

Kennet and Avon Canal, 78

Kilglass Lake, 225

Kilkenny-Castlecomer Canal scheme, 228

Kingstown Harbour, 240

Krantz, M., 48, 97, 108-9 
L

Lagan Navigation scheme, 225-6

La Louvière, lift at, I75

Lancashire and Yorkshire Railway, 6I-2, 76

Leech, Sir Bosdin, 36

Leeds and Liverpool Canal, 59, I85

Legislation, necessity for, $237-9$

Leicestershire and Northants Union Canal, 87

Lifts, use of, I75

Light Railways Act, the, I77

Liverpool Harbour Board, 2 I9

Lloyd, E. J., 92, 100, I59

Locks, sizes of Continental, I39 ; of American canals, I47 ; necessity for few, I74-5

Lurgan Canal scheme, 225-6

Manchester Ship Canal, 35-7, 234-37, 242-3

Maryborough Canal scheme, 228

Mas, M. de, 122, 169

Mexican Railways, 209

Miami-Erie Canal, I44

Millar, R., 75

Mississippi Canal, 8I, I43, I49-52

Mississippi Valley Commission, $\mathbf{I}_{50}$

Modernising Canals, need for, 229-3I

Monkland Canal, 22

Monopoly, Prevention of, I56-7

Montreal Gazette, 209

Montreal Route, the, 146

Morton, F., 167

Motive Power, 52-7

Mountmellich-Maryborough Canal scheme, 228

Municipal assistance, 242-3 
$\mathrm{N}$

Nationalisation, see State Control

Neagh, Canal scheme for Lough, 225-6, 228

Nettlefold's policy for killing competition, 94

Nore, River, 223

Nottingham Canal, 27

\section{O}

Ocean transport, $5^{1-3}$

Oder-Spree Canal, I26-7

Ohio Canal, I43, I49

Oise-Aisne Canal, 48

Oswego Canal, 147

Ouse Navigation Committee, 76

P

Paish, G., I79-8I

Peschaud, M., 212-4

Post Office Savings Bank and State control system, 195-6

Pratt, E. A., 66, 83-9o

Prevet, Senator Charles, 2II-12

R

Railway and Canal Traffic Act, 39-40, 186, 202, 236

Railway Nerws, 201

Railways, $19-25$; use of canals by, 28-32 ; control of, $38-9$; cost of building, 48-9; superiority over canals, 66-72 ; charges against, 76, 87 ; killing competition, 94 ; earnings of, $95-7$; benefited by waterways in Germany, I29; obstructive policy of, 233-8

Rankine, I6I

Rendall, T. H., 70

Revenue of Canals, 33

Revue Politique et Parlementaire, 212 
Rhine-Danube Canal, I25

Rhine-Hanover Canal, r23-4

Richmond, Weir at, I75

River improvements, 37

Roosevelt, T., I49-50

Saner, Mr., 29, 43, 50, 73, I59, 233

Seine Canals, 85 , I76

Severn, River, 234

Shannon, River, Weir on, I77 ; navigation scheme, 225 ;

State assistance, 240

Sheffield and South Yorks Navigation Co., 75, 93

Shropshire Union Canals, 32, 87-8, I85

Shuttleworth, Lord, 75, I28

Siemens and Halske, I73

State assistance, 240-4

State control, 197, 203, 207-19

Stratford-on-Avon Canal, 27

Strokestown Canal scheme, 225-6

Suez Canal, r9o, 240

Suir, River, 222-3, 228

Swiss State Railways, 207-8

Sympher, Herr, I29

Tate's evidence regarding freight, 145

Telhou Canal, 173

Thomas, G. C., 20, 27-8

Tolls, 76-7

Ton-mileage, $178-83$

Traffic returns, 30-r

Trent and Mersey Canal, 27, 29, 32, 86, I75 
Ulster Canal scheme, 225-6, 228

United States, see America

\section{V}

Vinci, Leonardo di, $\mathbf{r}_{52}$

\section{W}

Weaver Navigation, River, 21, 23, 62-3, 86, 103, 175, 219, 229

Weirs, $175-9,222$

Wells, L. B., quoted, 50

Williams, Sir E. Leader, 21, 63

Windom, Senator, I5I 
Tbe Gresbam 1press,

UNWIN BROTHERS, LIMITED,

WOKING AND LONDON. 
8. 8 


St wh

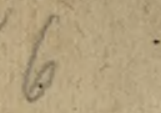

58

59

bo

63 
Biblioteka Politechniki Krakowskiej

|||||||||||||| ||| || ||||||||||||||||||

100000297238 